\title{
Estimates of Bridge Scour at Two Sites on the Virgin River, Southeastern Nevada, Using a Sediment-Transport Model and Historical Geomorphic Data
}

By Marsha M. Hilmes and J.E. Vaill

U.S. GEOLOGICAL SURVEY

Water-Resources Investigations Report 97-4073

Prepared in cooperation with the

NEVADA DEPARTMENT OF TRANSPORTATION

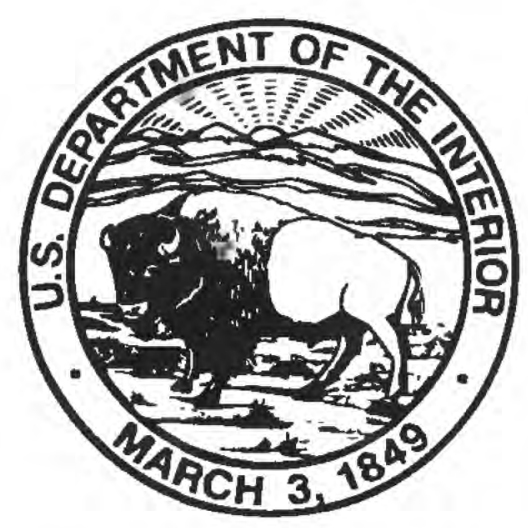

Carson City, Nevada 1997 


\title{
U.S. DEPARTMENT OF THE INTERIOR BRUCE BABBITT, Secretary
}

\author{
U.S. GEOLOGICAL SURVEY \\ GORDON P. EATON, Director
}

Any use of trade names in this publication is for descriptive purposes

only and does not constitute endorsement by the U.S. Government

For additional information

write to:

District Chief

U.S. Geological Survey

333 West Nye Lane, Room 203

Carson City, NV 89706-0866

email: usgsinfo_nv@usgs.gov

http://wwwnv.wr.usgs.gov
Copies of this report can be purchased from:

U.S. Geological Survey

Branch of Information Services

Box 25286

Denver, CO 80225-0286 

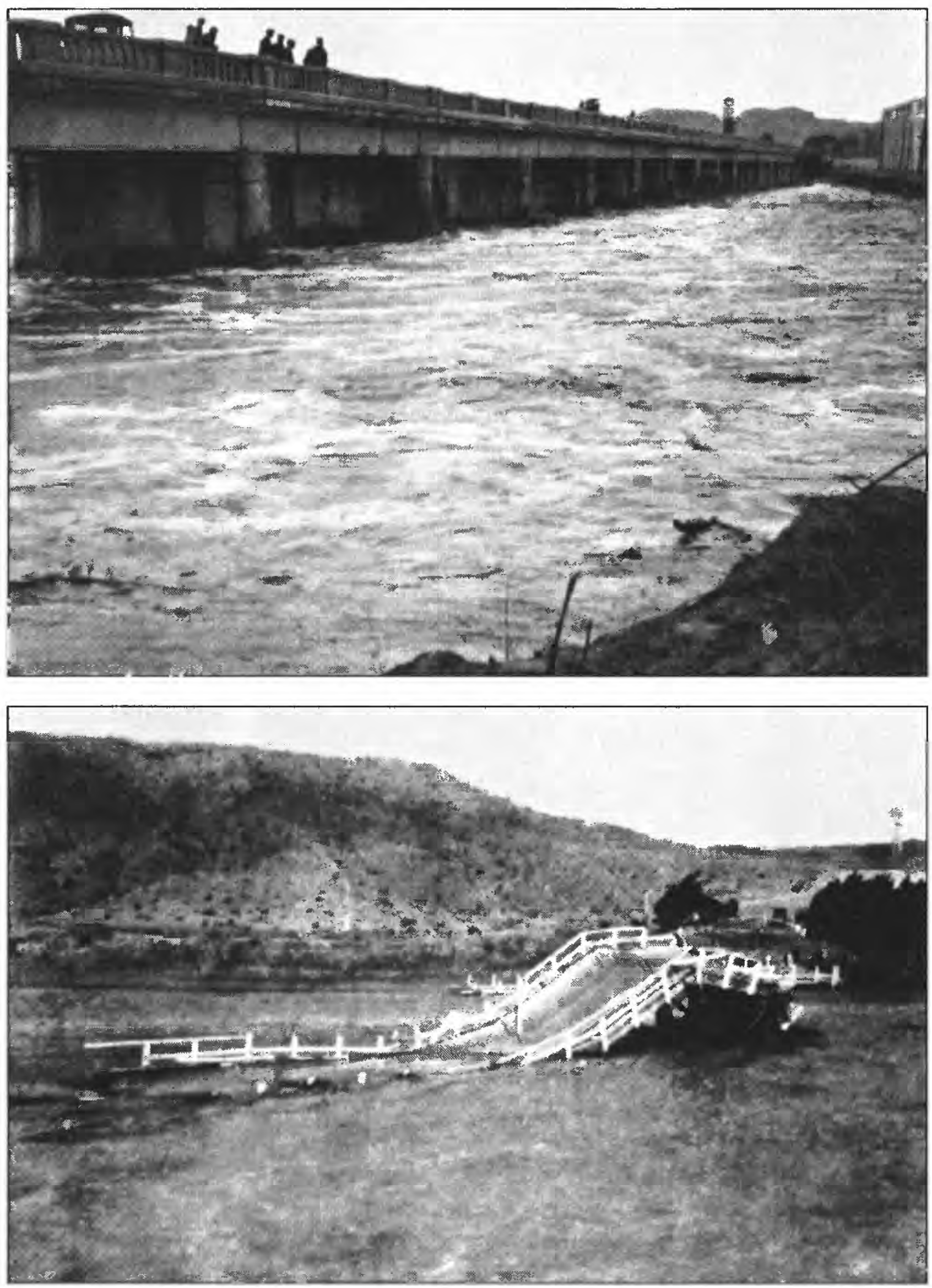

On February 9, 1932, a flood with a peak flow that may have exceeded 400 cubic meters per second (14,000 cubic feet per second) inundated the lower Virgin River. In the top photograph, people are standing on the recently completed bridge at Mesquite, Nev., during the flood. This bridge is still in place today. The view is from the south bank, looking north. Streamflow is from right to left. The structure on the right side of the photograph is the old bridge as seen in figure $6 A$ (within this report).

The bottom photograph shows the remains of the bridge at Riverside, Nev. This bridge was destroyed by the February 1932 flood. The view is northwestward, perhaps from a remnant of the bridge near the south bank. Streamflow is from right to left. This is the same bridge shown in figure $7 A$.

Photographs courtesy of the Nevada Historical Society (Clark County photographs 373 and 374 , respectively). 


\section{CONTENTS}

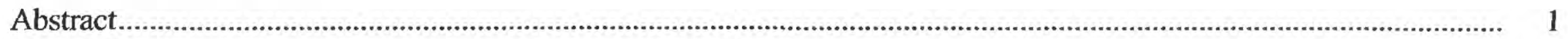

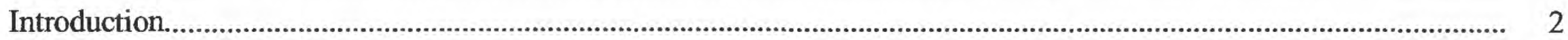

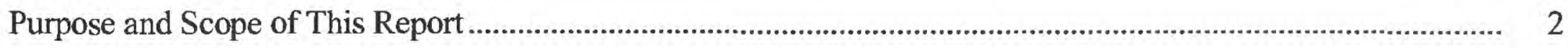

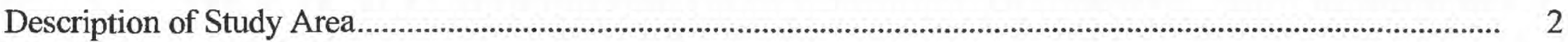

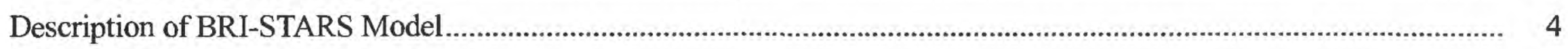

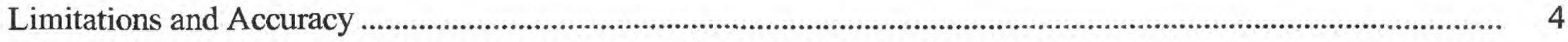

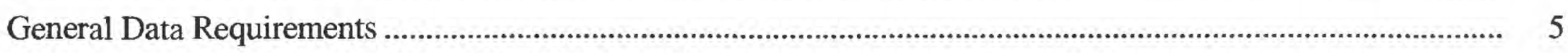

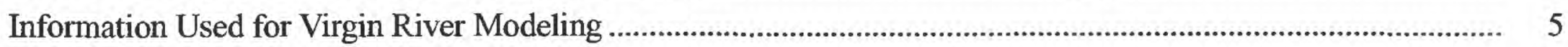

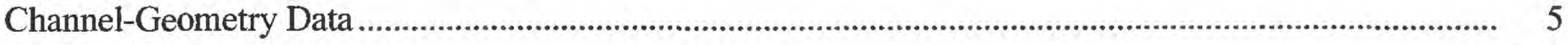

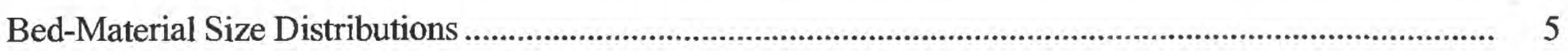

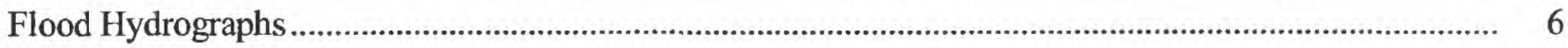

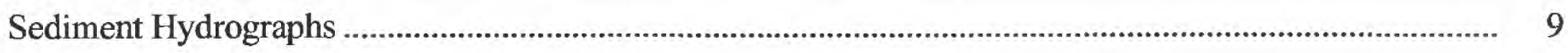

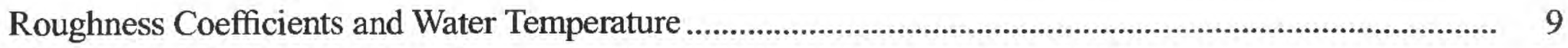

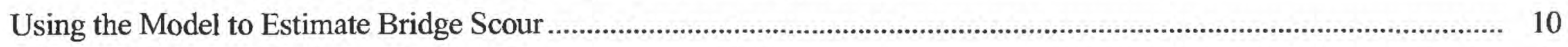

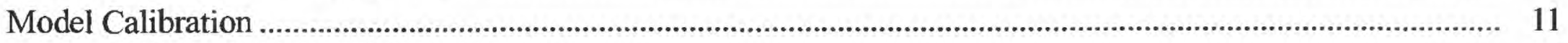

Scour Calculations for 100- and 500-Year Floods ............................................................................ 11

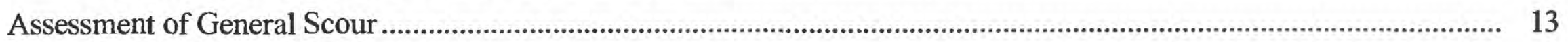

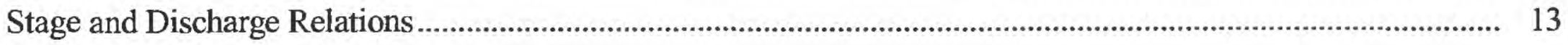

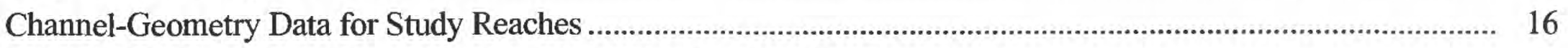

Channel-Geometry Data for Synthesized 100- and 500-Year Floods ......................................................... 16

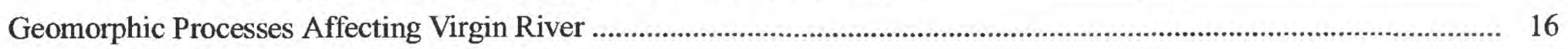

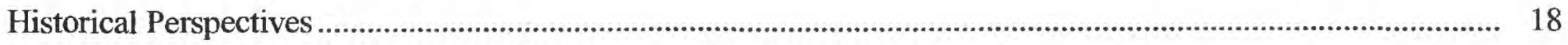

Observed Channel Changes Using Aerial Photography …..................................................................... 19

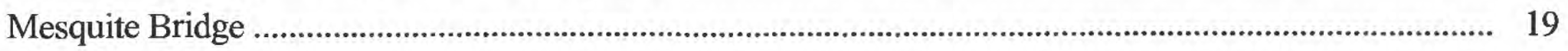

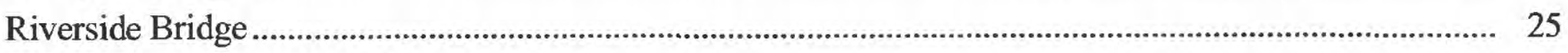

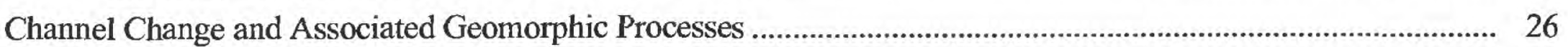

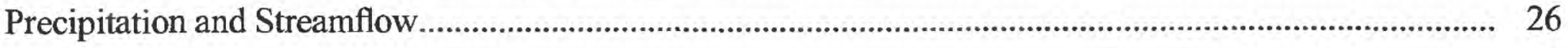

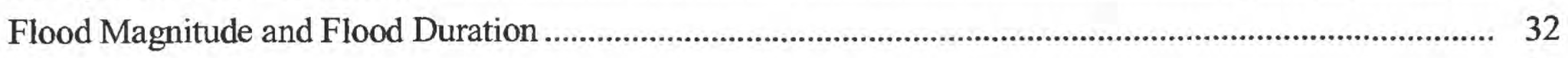

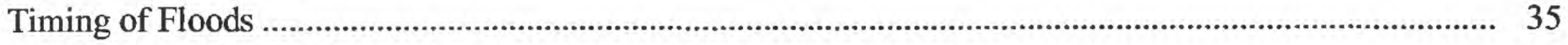

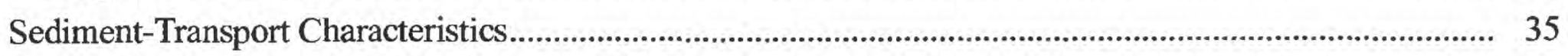

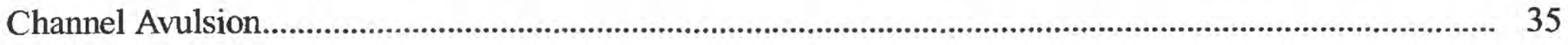

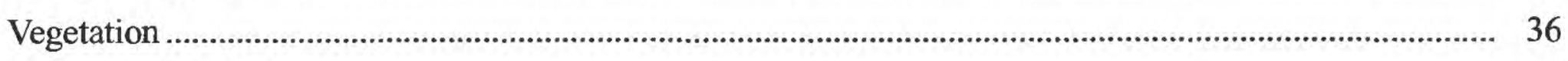

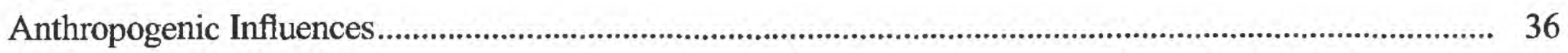

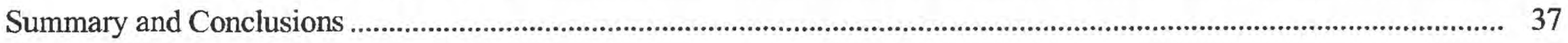

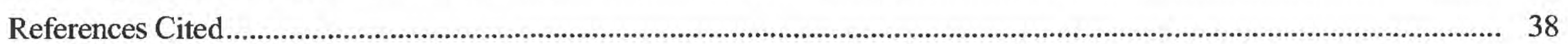

Appendix A: 1995 Surveyed Cross Sections in Relation to Resulting Model Cross Sections.......................................... 41

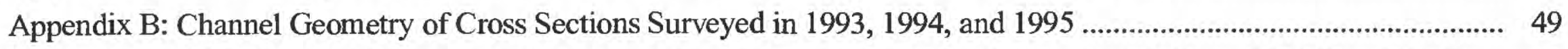

Appendix C: 1994 Channel Geometry in Relation to Channel Geometry After Synthesized 100- and 500-Year Floods.... 63

Appendix D: Name, Size, and Description of Input and Output Files for the Estimate of Bridge Scour on the

Virgin River, Southeastern Nevada. 


\section{FIGURES}

1. Map showing location of bridge sites, study reaches, and drainage area of Virgin River upstream from

Littlefield, Ariz., gaging station

2-5. Graphs showing:

2. Recorded March 1995 hydrographs and synthesized 100- and 500-year flood hydrographs for

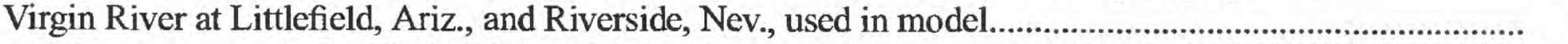

3. Flood-frequency curve for Virgin River at Littlefield, Ariz...................................................................... 8

4. Cross sections of channel-bed altitude for 1996 (initial altitudes) and for peak of 100-and 500-year floods at Mesquite and Riverside, Nev., bridges

5. Relation of stage, mean annual discharge, and peak discharge for Virgin River at Littlefield, Ariz., for 1929-95

6-7. Photographs showing:

6. Mesquite, Nev., bridge in 1924 and 1996.

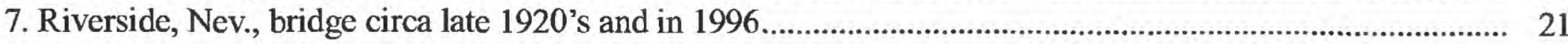

8-9. Aerial photographs showing:

8. Mesquite, Nev., bridge area in 1938, 1954, 1978, and 1995 ................................................................ 23

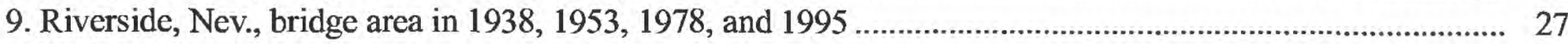

10-11. Graphs showing:

10. Mass curves of precipitation at St. George, Utah, and streamflow at Virgin River at Littlefield, Ariz. .......... 31

11. Annual peak discharge and annual mean discharge for Virgin River at Littlefield, Ariz. ............................. 33

12. Landsat Thematic Mapper images of Riverside, Nev., bridge area May 10, 1988, before Quail Creek Dam

failure, and April 11, 1989, after dam failure

\section{TABLES}

1. Location of cross section end points

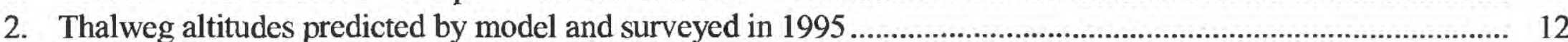

3. Simulated maximum contraction, channel, pier, and total scour or fill at Mesquite and Riverside, Nev., bridges for 100 -and 500 -year flood.

4. Channel change for surveyed cross sections, 1993-95 ............................................................................. 17

5. Depth of scour or fill calculated from model for 100 - and 500-year floods ............................................... 18

6. Inventory of digital imagery and aerial photography used for study of Virgin River........................................ 22

7. Flow angle of attack on Mesquite and Riverside, Nev., bridges as measured from aerial photographs............... 25

8. Summary of geomorphic characteristics and changes for four periods at Mesquite and Riverside bridge sites... 29

\section{CONVERSION FACTORS AND VERTICAL DATUM}

\begin{tabular}{rll}
\hline Multiply & By & To obtain \\
\hline cubic meter $\left(\mathrm{m}^{3}\right)$ & 0.0008107 & acre-foot \\
cubic meter per second $\left(\mathrm{m}^{3} / \mathrm{s}\right)$ & 35.31 & cubic foot per second \\
meter $(\mathrm{m})$ & 3.281 & feet \\
millimeter $(\mathrm{mm})$ & 0.03937 & inch \\
kilometer $(\mathrm{km})$ & 0.6214 & mile \\
metric ton per year & 1.102 & ton per year \\
square kilometer $\left(\mathrm{km}^{2}\right)$ & 0.3861 & square mile \\
\hline
\end{tabular}

Temperature: Degrees Celsius $\left({ }^{\circ} \mathrm{C}\right)$ can be converted to degrees Fahrenheit $\left({ }^{\circ} \mathrm{F}\right)$ by using the formula ${ }^{\circ} \mathrm{F}=\left[1.8\left({ }^{\circ} \mathrm{C}\right)\right]+32$. Degrees Fahrenheit can be converted to degrees Celsius by using the formula ${ }^{\circ} \mathrm{C}=0.556\left({ }^{\circ} \mathrm{F}-32\right)$.

Sea level: In this report, "sea level" refers to the National Geodetic Vertical Datum of 1929 (NGVD of 1929, formerly called "Sea-Level Datum of 1929"), which is derived from a general adjustment of the first-order leveling networks of the United States and Canada.

Water year: A water year is the 12-month period from October 1 through September 30 . The water year is designated by the calendar year in which it ends. 


\section{CONTRIBUTING U.S. GEOLOGICAL SURVEY STAFF}

\section{DATA-COLLECTION SUPPORT}

Lynn Metcalf, Hydrologist

Ronald F. Locke, Hydrologic Technician

Gary C. Gortsema, Hydrologic Technician

DeLoy C. Emmett, Hydrologic Technician

Darren D. Reeves, Hydrologic Technician

Thomas G. Kane, Hydrologic Technician

Ron P. Collins, Hydrologic Technician

Alan D. Robl, Hydrologic Technician

Daniel E. Hitch, Supervisory Hydrologic Technician
GIS AND REMOTE-SENSING SUPPORT

Brian D. Reece, Hydrologist

J. LaRue Smith, Hydrologist

Marianne August, Physical Scientist

PUBLICATIONS SUPPORT

Robin L. Sweet, Technical Editor

Shannon C. DeMeo, Editorial Assistant

J. Christopher Stone, Scientific Illustrator

TECHNICAL SUPPORT

K. Michael Nolan, Regional Surface-Water Specialist

Glen W. Hess, acting District Surface-Water Specialist

Stephen E. Hammond, Hydrologist

Joseph P. Capesius, Hydrologist 


\title{
Estimates of Bridge Scour at Two Sites on the Virgin River, Southeastern Nevada, Using a Sediment-Transport Model and Historical Geomorphic Data
}

\author{
by Marsha M. Hilmes and J.E. Vaill
}

\section{Abstract}

A bridge-scour study by the U.S. Geological Survey, in cooperation with the Nevada Department of Transportation, began in April 1996 to evaluate the Mesquite, Nevada, and Riverside, Nevada, bridges on the lower Virgin River using a sediment-transport model and historical geomorphic data. The BRIdge Stream Tube model for Alluvial River Simulation (BRI-STARS) was used to estimate bridge scour. The model was first calibrated using data for the Virgin River flood of March 12, 1995. Surveyed channel-geometry data were available at 11 cross sections for dates before and after the March 1995 flood to allow for evaluation of the model results. The model estimated the thalweg altitude within plus or minus 1 meter at 10 of the 11 cross sections.

The calibrated model then was used to estimate the contraction, channel, pier, and total scour for synthesized hydrographs for 100- and 500-year floods at the two bridge sites. The estimated maximum total scour at the Mesquite bridge was 1.30 meters for the 100-year flood and 1.32 meters for the 500-year flood. The maximum total scour at the Riverside bridge was 1.90 meters for the 100 year flood and 2.01 meters for the 500-year flood.

General scour was evaluated using stagedischarge relations at nearby streamflow-gaging stations, 1993-95 channel-geometry data, and channel-geometry data for the 100 - and 500-year floods. On the basis of stage and discharge at the Littlefield, Arizona, gaging station, no long-term trend in aggradation or degradation was found.
However, several cycles of aggradation and degradation had occurred during the period of record; the difference between the highest and lowest stage was 0.87 meter for a chosen low-flow discharge of 5.66 cubic meters per second for 192995 . The value of 0.87 meter is probably the best estimate of general scour. The cross sections had an average scour depth of 0.07 meter between 1993 and 1994 and 0.16 meter between 1994 and 1995. The model simulated little general scour for the 100- and 500-year floods at the cross sections and did not give a good estimate of general scour, probably because the duration (days) of the floods used in the model was relatively short when compared with the duration (months or years) of geomorphic processes that influence long-term aggradation or degradation.

Historical geomorphic changes of the Virgin River at the bridge sites and the causes of those changes were documented using aerial photographs from 1938-95 and other historical information. The Virgin River has become narrower and more sinuous through time, the vegetation on the flood plain has increased, and the channel has shifted laterally many times. The processes associated with these channel changes were found to be long-term changes in precipitation and streamflow; the duration, magnitude, and timing of floods; sediment-transport characteristics; channel avulsion; changes in density of vegetation; and anthropogenic influences. 


\section{INTRODUCTION}

The Nevada Department of Transportation (NDOT) has determined that the bridges at Riverside, Nev., (B-85) and Mesquite, Nev., (B-89) on the lower Virgin River will be replaced in the near future. The Federal Highway Administration (FHWA) has recognized the need for better procedures of designing bridges for scour (Richardson and Davis, 1995). The FHWA, as outlined by Richardson and Davis (1995), recommends that a bridge be designed to withstand the effects of scour from a 500-year flood, or a flow 1.7 times the 100-year flood when the 500-year flood is unknown. Scour depths can be computed from data in a detailed hydraulic analysis that uses procedures recommended by Richardson and Davis (1995) or by a fluvial study using either a physical or a digital model. The BRIdge Stream Tube model for Alluvial River Simulation (BRI-STARS; Molinas, 1990) is a digital model that has been used to compute sediment transport and to simulate scour depths at bridges in previous studies (Vaill, 1995; Waltemeyer, 1995). Another important aid in the bridge-design process is an understanding of the geomorphic processes acting on the river in combination with bridge scour.

The U.S. Geological Survey (USGS), in cooperation with NDOT, began a study in April 1996 to evaluate scour at the Mesquite and Riverside bridges on the Virgin River. Data for 1994 (prior to the flood of March 1995) were used as input to BRI-STARS and the model was calibrated to the documented channel changes at and near the two bridge sites resulting from the March 1995 flood. Then the calibrated model was used to compute scour depths for 100- and 500-year floods. An additional part of the study was to describe the geomorphic processes in the study area. This information will be used by NDOT to aid in the design process for the new bridges.

The flood of March 12, 1995, on the Virgin River caused major channel changes (lateral migration of the thalweg, aggradation, and degradation). These changes were documented by channel-geometry data collected in water years 1994 and 1995 by the USGS. The instantaneous peak flow recorded at the USGS streamflowgaging station at Littlefield, Ariz. (number 09415000), hereafter referred to as the Littlefield gaging station, was $581 \mathrm{~m}^{3} / \mathrm{s}$. This peak flow was approximately a 25 year flood based on a log-Pearson Type III analysis (Interagency Advisory Committee on Water Data, 1982) of 64 years of record.

\section{Purpose and Scope of This Report}

This report describes the application of BRISTARS to evaluate the documented channel changes between field-surveyed cross-section data collected before and after the flood of March 12, 1995, and to estimate scour depths for 100- and 500-year floods. The report also describes the historical geomorphic changes and associated geomorphic processes within the study area as documented by several methods.

Historical aerial photography, channel-geometry data, bed-material particle-size distributions, sediment-discharge data, and continuous streamflow data are available for the Virgin River within the study area. The amount of information provides a unique opportunity to apply the BRI-STARS model to compute channel aggradation and degradation during a flood and to compare the results with documented channel changes. These historical data also help to define the geomorphic processes acting within the study area.

\section{Description of Study Area}

The Virgin River begins above Zion National Park, Utah, at an altitude of 2,621 m above sea level, and flows southwestward through Kane and Washington Counties in Utah, before entering the Virgin River Gorge (fig. 1). The lower Virgin River begins where the river exits the Virgin River Gorge in Mohave County, Ariz., at an altitude of $560 \mathrm{~m}$. Upon exiting the gorge, the Virgin River flows westward and then southward through Mohave County, Ariz., and into Clark County, Nev., before entering Lake Mead, Nev., at an altitude of $366 \mathrm{~m}$. The study area is within the Virgin River Hydrographic Area. ${ }^{1}$ The lower Virgin River Valley, 0.3-1 km wide, is entrenched in terrace deposits of Quaternary age, the highest being $85 \mathrm{~m}$ above the modern channel.

The USGS operates two streamflow-gaging stations on the Virgin River. The Littlefield gaging station (number 09415000) has a drainage area of $13,183 \mathrm{~km}^{2}$ (fig. 1) and has been a continuousrecording site since 1929 . The mean annual flow

\footnotetext{
${ }^{1}$ Formal hydrographic areas in Nevada were delineated systematically by the U.S. Geological Survey and Nevada Division of Water Resources in the late 1960's (Rush, 1968; Cardinalli and others, 1968) for scientific and administrative purposes. The official hydrographic-area names, numbers, and geographic boundaries continue to be used in U.S. Geological Survey scientific reports and Division of Water Resources administrative activities.
} 


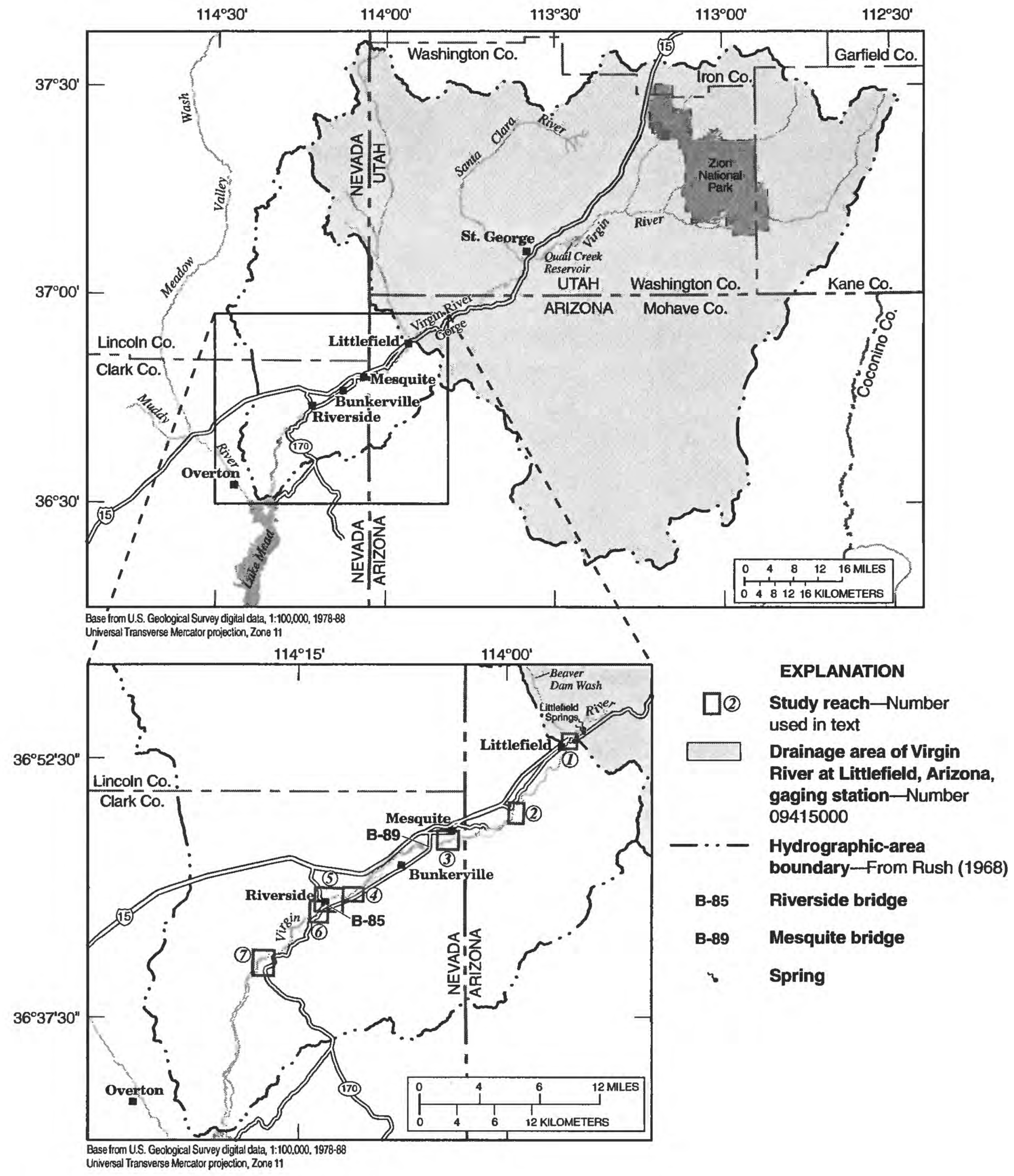

Figure 1. Location of bridge sites, study reaches, and drainage area of Virgin River upstream from Littlefield, Ariz., gaging station. WMA, Wildlife Management Area. 
for the period of record is $6.9 \mathrm{~m}^{3} / \mathrm{s}$. The highest instantaneous peak flow was $1,730 \mathrm{~m}^{3} / \mathrm{s}$ on January 1,1989 , as a result of the Quail Creek Dam failure near St. George, Utah. The highest natural instantaneous peak flow was $997 \mathrm{~m}^{3} / \mathrm{s}$ on December 12,1966 . The instantaneous peak flow for water year 1995 was 581 $\mathrm{m}^{3} / \mathrm{s}$ on March 12 . The sediment record at Littlefield, Ariz., consists of daily sediment data for 1947-68, periodic data for 1977-79 and 1986-92, and daily sediment data for 1992-95. At Littlefield, Ariz., the mean annual air temperature is $18^{\circ} \mathrm{C}$ and the mean annual rainfall is $16 \mathrm{~cm}$ (National Climatic Data Center, 1992).

The Virgin River near Riverside, Nev., gaging station (number 09415190), hereafter referred to as the Riverside gaging station, has a drainage area of 15,488 $\mathrm{km}^{2}$ and was operated from December 1970 to September 1974 and from October 1992 to December 1995. The gage is approximately $1 \mathrm{~km}$ downstream from the Riverside bridge (B-85; fig. 1). The instantaneous peak flow recorded during the period of record was $498 \mathrm{~m}^{3} / \mathrm{s}$ on September 20,1972. The instantaneous peak flow on March 12, 1995, was $425 \mathrm{~m}^{3} / \mathrm{s}$. The sediment record at Riverside, Nev., consists of daily sediment data for 1992-94 and periodic data for 1994-95. Historical climate data are not available at Riverside, Nev.; however, climatic conditions are similar to those at Littlefield, Ariz.

Several reaches along the Virgin River from near Littlefield to downstream from Riverside (reaches 1 through 7 on fig. 1) have available channel-geometry information, bed-material particle-size data, historical aerial photography, and other geomorphic data. The upstream bridge (B-89) at Mesquite is approximately $1.5 \mathrm{~km}$ downstream from reach 3 . The downstream bridge (B-85) near Riverside is within reaches 5 and 6 , which overlap each other (fig. 1).

\section{DESCRIPTION OF BRI-STARS MODEL}

The object of the BRI-STARS model (Molinas, 1990 ) is to study complicated sedimentation problems where the flowing water-sediment mixture interacts with the alluvial river-channel boundaries. To accomplish this, the water-surface profile and other hydraulic variables must be computed without interruption for subcritical, supercritical, or a combination of both flow conditions during a specified time step. BRI-STARS has three major components: (1) step-backwater computations for water-surface profiles, (2) sediment-routing computations, and (3) stream-power minimization computations. At each time step, these components are linked together to (1) provide water-surface profile computations for the entire channel reach, (2) compute the lateral locations of the stream tubes ${ }^{1}$ and other hydraulic variables for each stream tube, and (3) route sediment transport through each stream tube satisfying the sediment continuity equation. At the end of these computations for each time step, bed-material compositions are revised and channel-bed altitudes are adjusted for the next time step.

\section{Limitations and Accuracy}

Computer modeling of stream sedimentation problems is not an easy task because the problems tend to be multidisciplinary and multidimensional. Sedimentation models have the limitations of being heavily data dependent and of being limited to the character ranges of the data used to develop them. In the numerical modeling of river systems, many variables require value assignments to properly execute the computational processes. An advisory committee (Fan, 1988 , p. 23) has stated that "computer modeling of sedimentation problems is in the developmental stages, it is not a true representation, but at best, an approximation of the solution to a problem."

Owing to a lack of data during natural phenomena and to operating conditions in physical experiments, these variables may have a large range of acceptable values. Accuracy of the model depends on how close the values assigned to variables are to true values of the river system.

Molinas (1990, p. 73) indicates the relative importance of the variables used in sediment routing models. The importance is also a measure of the sensitivity of the variables. If a variable has a high level of sensitivity, the model output will differ significantly with small changes in the input variable and the input variable value will need to be close to the value that occurs naturally. A variable that has a low level of sensitivity has a wider range of input values that can be used in the model before substantial changes in the model output result. Unlike many other sedimentation modeling projects, an observed data base for the Virgin River was available for use in this study to calibrate the model. Actual data values were available for all variables identified by Molinas (1990) as having a high degree of importance in increasing the degree of

\footnotetext{
${ }^{1} \mathrm{~A}$ stream tube is a section of channel that carries a constant discharge along its length.
} 
accuracy for model results. Therefore, results of applying the BRI-STARS model in the Virgin River should compare favorably with results from other BRISTARS applications.

\section{General Data Requirements}

Data requirements for the model are channel geometry, bed-material size distributions, hydrographs (streamflow and sediment-inflow), water-surface altitudes at the initial downstream cross section, water temperature, roughness coefficients, and a sedimenttransport equation. Model-input data are available upon request from the USGS, Nevada District office, Carson City, Nev. (appendix D).

Channel geometry can be determined from field surveys of cross sections or from topographic maps. Cross sections can be synthesized at different locations in the study reach by extending survey data using valley slopes from field surveys or computed from topographic maps. Bed-material size distributions are determined from sieve analyses of samples collected at the study sites or from particle counts from the study sites. Recorded hydrographs from streamflow-gaging stations can be used in the model or synthetic hydrographs may be used after they have been divided into periods of equal discharge for a given time step (discretized). Sediment hydrographs based on recorded data can be used in the model or the model can be allowed to create a sediment-inflow hydrograph using a specified sediment-transport equation and data on the size distribution of bed material. Initial water-surface altitudes are determined from stage-discharge relations developed for the initial cross section or from a separate computation analysis of water-surface profiles. Water temperatures can be estimated or a measured value can be used in the model. Roughness coefficients for the channel and flood plain can be estimated during a field inspection of the study sites or from inspection of aerial photography and ground photographs of the sites.

\section{Information Used for Virgin River Modeling}

\section{Channel-Geometry Data}

Channel-geometry data are available from field surveys done in 1993, 1994, and 1995 for 23 cross sections in seven reaches of the study area (fig. 1). The Universal Transverse Mercator (UTM) coordinates of the 23 surveyed cross section end points are listed in table 1 . Not all of the historical cross sections were used in the model because some were too closely spaced, resulting in computation problems. The 1994 cross sections used in the model are indicated in table 1. Cross sections surveyed after the March 1995 flood were used for comparison with cross sections generated by BRI-STARS to determine how accurately the model simulated the observed channel changes.

To supplement the historical cross sections, additional cross sections were synthesized by extending surveyed data using valley slopes computed from topographic maps and from the shape of surveyed cross sections. Cross-section data from an indirect determination of discharge at the Mesquite bridge in January 1989 (following the Quail Creek Dam failure) were included to supplement the historical cross-section data. Cross sections at the downstream opening of each bridge site were surveyed in May 1996. Cross sections one bridge width upstream from the bridge (approach section) and one bridge width downstream from the bridge (exit section) were determined from $0.61-\mathrm{m}$ contour maps provided by NDOT.

Two subreaches that include the bridge sites and historical cross sections were selected for use in BRI-STARS. The length of each subreach selected and the cross sections used differed depending on the cross-section spacing and location. The subreaches were selected to include as many historical cross sections as feasible on the basis of the amount of synthesized data required between surveyed sites and the increase in computational time required for model completion.

The subreach selected for model input for the Mesquite bridge (B-89) near Mesquite, Nev., extended from $13,716 \mathrm{~m}$ upstream from the bridge to $5,182 \mathrm{~m}$ downstream from the bridge and included five historical cross sections in reaches 2 and 3 . The subreach selected for model input for the Riverside bridge (B-85) near Riverside, Nev., extended from 6,096 m upstream from the bridge to $2,286 \mathrm{~m}$ downstream from the bridge and included six historical cross sections in reaches 4,5 , and 6 .

\section{Bed-Material Size Distributions}

Bed-material size distributions at the cross-section locations were available from samples collected in 1994 and 1995. The 1995 data (Bauer and others, 1996, p. 537-539) were used for model input unless the data were not available, such as when the sites could not be sampled due to streamflow conditions, then the 1994 data (Clary and others, 1995, p. 564-569) were used. 
Table 1. Location of cross-section end points, Virgin River, Nev. and Ariz.

[UTM, Universal Transverse Mercator coordinate grid]

\begin{tabular}{|c|c|c|c|c|c|c|}
\hline \multirow[b]{2}{*}{$\begin{array}{c}\text { Cross } \\
\text { section }\end{array}$} & \multicolumn{3}{|c|}{ Right-bank end point } & \multicolumn{3}{|c|}{ Left bank end point } \\
\hline & $\begin{array}{c}\text { UTM } \\
\text { X-coordinate } \\
\text { (meters) }\end{array}$ & $\begin{array}{c}\text { UTM } \\
\text { Y-coordinate } \\
\text { (meters) }\end{array}$ & $\begin{array}{c}\text { Altitude } \\
\text { (meters above } \\
\text { sea level) }\end{array}$ & $\begin{array}{c}\text { UTM } \\
\text { X-coordinate } \\
\text { (meters) }\end{array}$ & $\begin{array}{c}\text { UTM } \\
\text { Y-coordinate } \\
\text { (meters) }\end{array}$ & $\begin{array}{c}\text { Altitude } \\
\text { (meters above } \\
\text { sea level) }\end{array}$ \\
\hline $1-1$ & 774101.086 & 4087033.696 & 544.341 & 774174.108 & 4086970.783 & 541.747 \\
\hline $1-2$ & 774077.793 & 4086997.369 & 544.749 & 774165.640 & 4086950.276 & 541.041 \\
\hline $1-3$ & 774055.746 & 4086952.485 & 544.499 & 774155.112 & 4086919.974 & 541.323 \\
\hline $1-4$ & 774031.639 & 4086919.499 & 544.258 & 774156.736 & 4086901.778 & 541.618 \\
\hline $2-1^{a}$ & 768217.016 & 4079433.685 & 503.430 & 768289.337 & 4079337.301 & 504.187 \\
\hline $2-2$ & 768149.062 & 4079230.715 & 504.944 & 768294.122 & 4079241.089 & 514.942 \\
\hline $2-3^{a}$ & 769159.499 & 4079055.657 & 506.672 & 768280.303 & 4079177.492 & 510.562 \\
\hline $3-1^{a}$ & 761492.433 & 4076187.121 & 478.184 & 761631.997 & 4075893.665 & 479.545 \\
\hline $3-2^{a}$ & 761470.527 & 4076147.985 & 478.095 & 761547.637 & 4075898.928 & 482.221 \\
\hline $3-3^{a}$ & 761345.948 & 4076257.599 & 478.780 & 761463.866 & 4075915.849 & 478.262 \\
\hline $3-4$ & 761113.517 & 4076093.572 & 477.047 & 761305.200 & 4075799.056 & 480.619 \\
\hline $4-1^{a}$ & 751088.126 & 4070364.008 & 449.879 & 751563.584 & 4069691.687 & 444.578 \\
\hline $4-2$ & 751033.736 & 4070324.308 & 448.876 & 751438.809 & 4069645.581 & 445.071 \\
\hline $4-3^{2}$ & 750922.244 & 4070222.323 & 443.193 & 751266.011 & 4069635.727 & 442.952 \\
\hline $5-1^{a}$ & 749270.276 & 4069730.960 & 446.014 & 749660.644 & 4068996.130 & 438.070 \\
\hline $5-2$ & 749040.749 & 4069809.989 & 450.066 & 749505.478 & 4068919.132 & 437.447 \\
\hline $5-3^{a}$ & 748634.848 & 4069572.057 & 438.821 & 749058.260 & 4068762.300 & 442.977 \\
\hline $5-4^{a}$ & 748344.404 & 4069383.060 & 437.268 & 748699.746 & 4068717.551 & 438.704 \\
\hline $6-1^{a}$ & 747663.267 & 4068272.336 & 428.414 & 747828.064 & 4068144.385 & 426.480 \\
\hline $6-2$ & 747615.696 & 4068169.894 & 429.576 & 747772.873 & 4068057.659 & 427.292 \\
\hline $7-1$ & 742215.536 & 4062869.530 & 421.269 & 742371.248 & 4062511.351 & 407.735 \\
\hline $7-2$ & 741461.040 & 4062787.705 & 409.238 & 741789.091 & 4062481.970 & 407.504 \\
\hline $7-3$ & 741289.802 & 4062185.748 & 408.359 & 741708.250 & 4062160.759 & 405.444 \\
\hline
\end{tabular}

${ }^{a}$ Cross section used as channel geometry input to BRI-STARS computer model.

The size distributions were determined from sieve analyses of the samples using 11 standard sieve sizes $(0.0625$ to $64 \mathrm{~mm})$ or random-walk particle counts of 100 clasts (Wolman, 1954) at the cross sections. Generally, a cobble armor layer with a sand layer on top, which changes in depth with space and time, is found throughout the study area. This armoring effect was accounted for in the model by limiting the thickness of the active layer.

\section{Flood Hydrographs}

The periods selected for model calibration were March 1-20, 1995, for the Mesquite bridge and March 10-16 for the Riverside bridge. The period used for the Riverside bridge was less than that for the Mesquite bridge because discharge data were missing when the stream gage malfunctioned prior to the March 12 peak and on the recession after March 13. The recorded hydrographs used in the model are shown in figure 2. The March flood was selected for modeling because observed changes during the January and February floods were minimal. Longer periods were not modeled because BRI-STARS does not include algorithms that adequately describe the dynamic processes of bank saturation from previous high flows and mass wasting that would have contributed to the antecedent conditions of the March flood.

A 2-hour time step was selected for use in the model for the Mesquite bridge and discharge values were selected from the recorded hydrograph for March $1-20,1995$, from the Littlefield gaging station. A 1.5hour time step was selected for use in the model for the Riverside bridge and discharge values were selected from the recorded hydrograph for March 10-16, 1995, 
A.
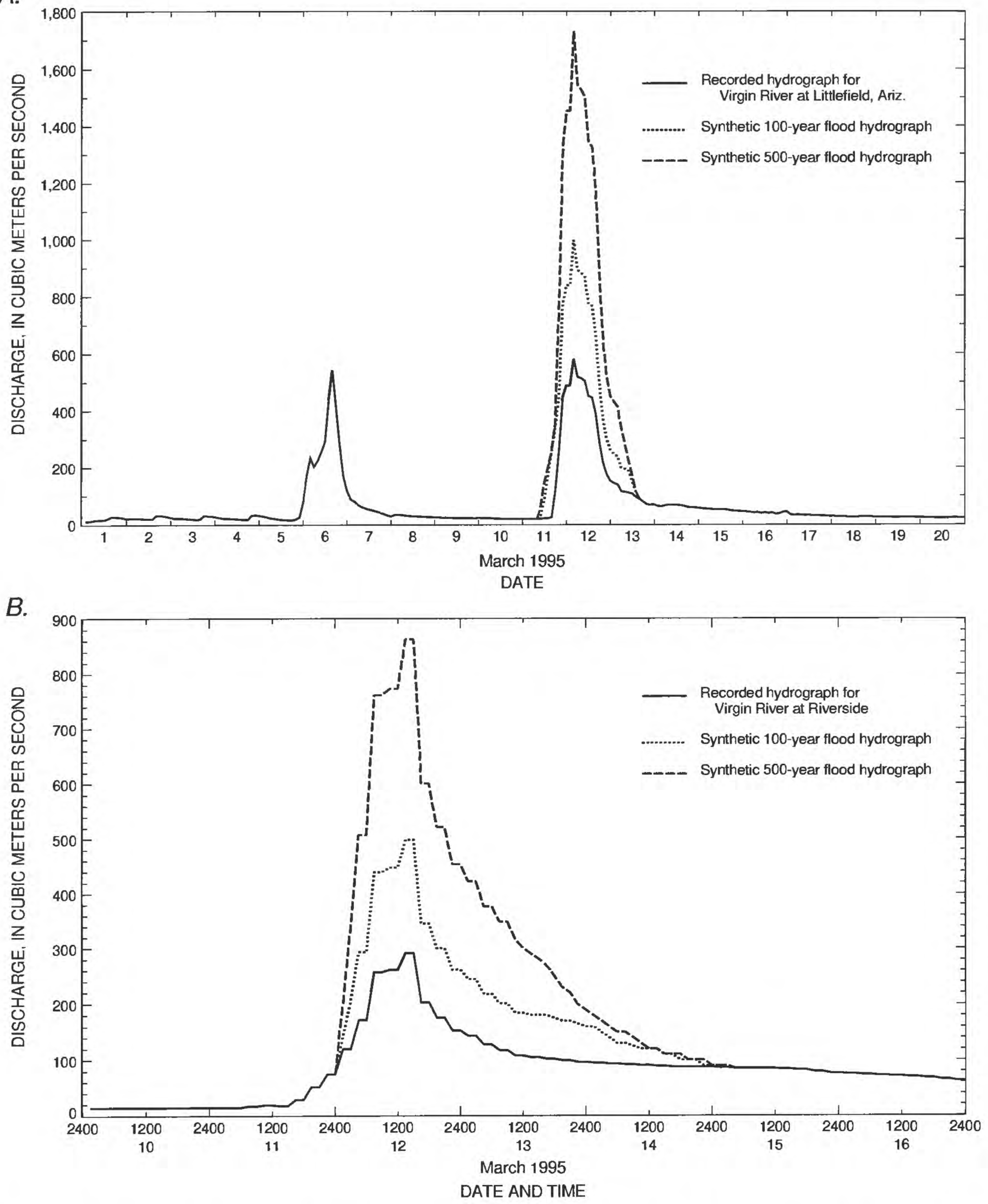

Figure 2. Recorded March 1995 hydrographs and synthesized 100- and 500-year flood hydrographs for Virgin River at $(A)$ Littlefield, Ariz., and (B) Riverside, Nev., used in model. Synthetic hydrographs are not date or time specific. 
from the Riverside gaging station. Initial water-surface altitudes at the most downstream cross section for each discharge value selected in each channel reach modeled were determined by a slope-conveyance computation at the cross section.

Magnitudes of the 100-and 500-year floods were computed from a log-Pearson Type III analysis (Interagency Advisory Committee on Water Data, 1982) of 64 years of record at the Littlefield gaging station (1930-94) that excluded the 1989 Quail Creek Dam failure flood. No log-Pearson Type III analysis was made for the Riverside gaging station due to the short period of record (less than the 10 years recommended by the Interagency Advisory Committee on Water Data, 1982). The flood-frequency curve for the Littlefield gaging station is shown in figure 3 .

The magnitude of the 100-year flood at the Littlefield gaging station was determined to be $969 \mathrm{~m}^{3} / \mathrm{s}$ and the 500 -year flood was $1,597 \mathrm{~m}^{3} / \mathrm{s}$. On the basis of the flood-frequency analysis for the Mesquite bridge, the December 1966 flood $\left(997 \mathrm{~m}^{3} / \mathrm{s}\right)$ was approximately equal to the 100-year flood. The 1989 Quail Creek

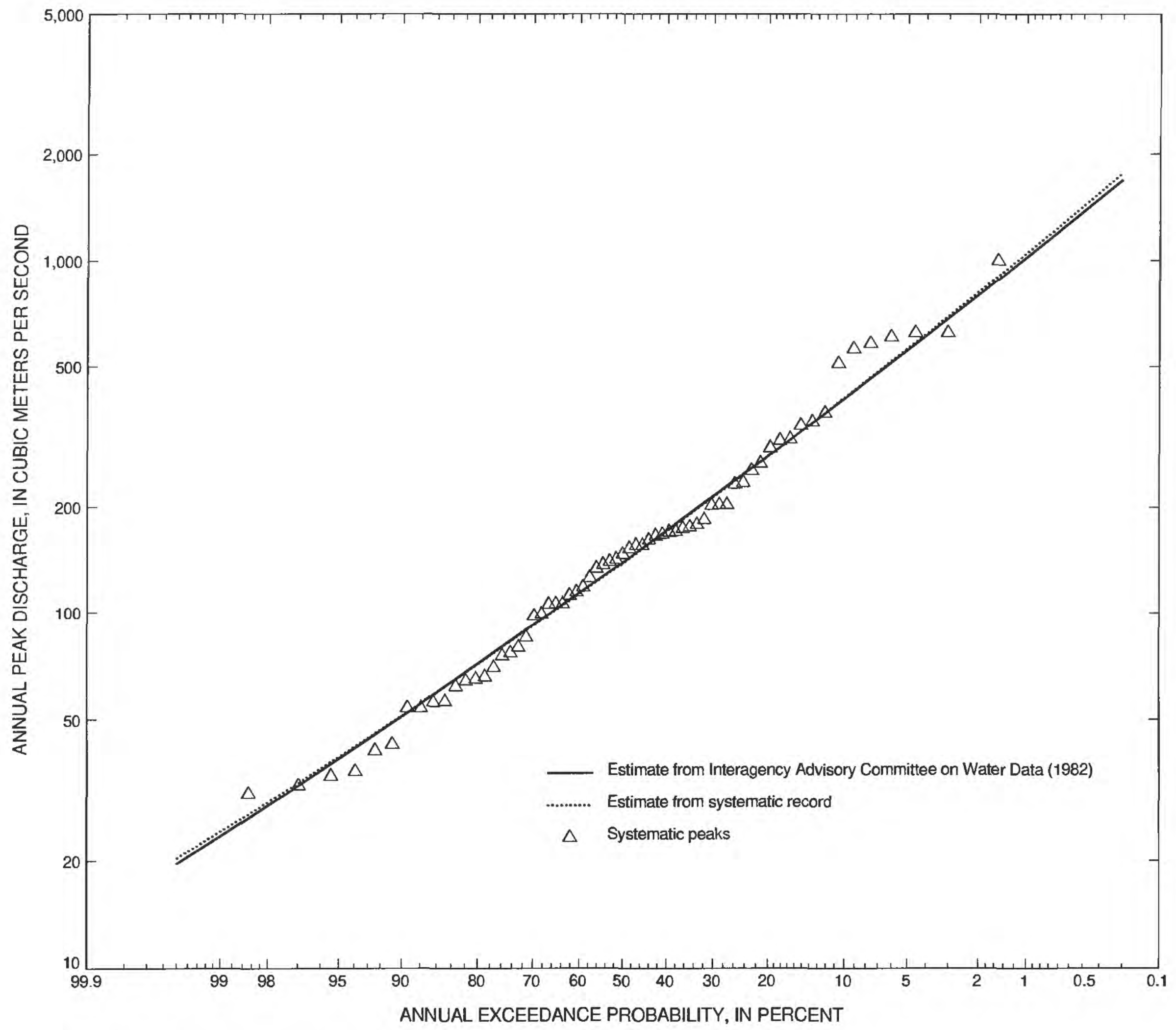

Figure 3. Flood-frequency curve for Virgin River at Littlefield, Ariz. (gaging station 09415000). 
Dam failure flood $\left(1,730 \mathrm{~m}^{3} / \mathrm{s}\right)$ was approximately equal to the 500-year flood. Therefore, the 1966 and 1989 flood magnitudes only were used to represent the magnitudes of the 100- and 500-year floods, respectively, in the hydrograph synthesis.

Attenuation of peaks between the Littlefield and Riverside gaging stations was found to be approximately 30 percent on the basis of comparison of concurrent recorded hydrographs at the two gaging stations. For the Riverside bridge, the 1972 flood peak recorded at the Riverside gage was approximately equal to the 100 -year flood when the 30 percent attenuation is applied to the flood frequency curve (fig. 3) for the Littlefield gaging station.

Synthesized hydrographs were developed for the 100- and 500-year floods by applying a ratio to the recorded March flood hydrographs. The value used to increase the recorded March hydrographs was computed as the ratio of the design-flood magnitude (100- and 500-year) and the magnitude of the peak on March 11-12. The ratios used at the Mesquite bridge were 1.72 for the 100-year flood hydrograph and 2.98 for the 500-year flood hydrograph. The ratios used for the Riverside bridge were 1.71 for the 100 -year flood hydrograph and 2.96 for the 500 -year flood hydrograph. This approach was used to simulate flood peaks that are representative of an actual storm and of antecedent conditions common to the time of year when most flooding takes place. These synthesized flood hydrographs are shown in figure 2 .

The synthesized flood hydrographs described above were compared to flood hydrographs developed using a method described by Eychaner (1976). This method is based on analysis of 364 floods from 18 continuous gaging stations in the Colorado River Basin of southern Utah. The drainage area for the Littlefield gage is considerably greater than the range of drainage areas used to develop the Eychaner method (13-777 $\mathrm{km}^{2}$ ) and may be a limitation of using this method. The shape and duration of the synthetic hydrographs developed using the method described by Eychaner (1976) were evaluated by comparison with the hydrographs for the peak flows of record at the Littlefield gaging station in water years $1967\left(997 \mathrm{~m}^{3} / \mathrm{s}\right)$ and $1989(1,730$ $\mathrm{m}^{3} / \mathrm{s}$ ). In general, the hydrographs developed using the method from Eychaner (1976) resulted in a shorter duration of the peak flow than recorded by hydrographs for naturally occurring floods. Therefore, on the basis of this analysis, the synthetic 100- and 500-year flood hydrographs developed by applying a ratio to the March 11-12 flood hydrograph were used in the model.

\section{Sediment Hydrographs}

Bridge scour is limited by the availability of bed material and the capacity of the stream to transport eroded material. The sediment-inflow hydrograph at the most upstream cross section in a study reach can be supplied from sediment-discharge data, or the model can develop a sediment-inflow hydrograph based on the sediment-transport equation. If a sediment-inflow hydrograph is available, BRI-STARS requires it to be supplied in the form of discretized sediment discharges. If the model develops a sediment-inflow hydrograph, BRI-STARS uses a specified sedimenttransport equation from the model and the bed-material-size data to produce a sediment-inflow hydrograph at the most upstream cross section. Current options in the model for selection of a sediment-transport equation have been defined by Chang (1988) and are (1) the 1973 Yang method, (2) the Acker and White method, (3) the Engelund and Hansen method, and (4) the Meyer-Peter Mueller method. A fifth option is to supply a generic equation of a given form. The equations from the different methods are applicable to particle sizes of $0.0625 \mathrm{~mm}$ and greater.

No previously determined sediment-transport equations were available for the study sites. On the basis of a calibration analysis of the equations available for use in the model, the 1973 Yang method was selected for the Mesquite bridge study reach where the predominant bed-material size was sand and the Meyer-Peter Mueller method was selected for the Riverside bridge where the predominant bed-material sizes were relatively coarse sand. The methods used in this study were chosen for the model because of their accuracy and the short computational times associated with them. The calibration analysis was done by determining which equation resulted in the best comparison of the 1995 data with the model results. BRI-STARS was allowed to develop sediment-inflow hydrographs at both sites using the specified equations and the available bed-material data.

\section{Roughness Coefficients and Water Temperature}

Roughness coefficients were selected by visual observation in the field during the 1996 survey of the bridge sites. The coefficients were modified slightly after inspection of numerous photographs taken during the field surveys. Roughness coefficients used in the model ranged from 0.035 to 0.038 in the main channel and from 0.060 to 0.070 for the flood plain in the 
Mesquite bridge reach and from 0.032 to 0.040 in the main channel and from 0.050 to 0.065 for the flood plain in the Riverside bridge reach. Water temperature was assumed to be $18.3^{\circ} \mathrm{C}$ for all floods modeled although BRI-STARS is not sensitive to temperature.

\section{USING THE MODEL TO ESTIMATE BRIDGE SCOUR}

Scour is the result of the erosive action of flowing water as it excavates and carries away material from the bed and banks of the stream. All streambed material is susceptible to scour, but the magnitude of scour depth primarily depends on site conditions and hydraulic characteristics of the bridge reach, so each site is unique. The rate at which maximum scour is reached depends on the ability of the streambed material to withstand the factors that cause scour. Total scour at a river crossing consists of three components that, in general, are additive:

1. General scour - long-term changes in the riverbed altitude, whether from natural or humaninduced causes;

2. Contraction scour - constriction of the channel, either naturally or due to the bridge, and the bridge approaches encroaching on the flood plain; and

3. Local scour - interference of the flow pattern by piers or abutments that accelerate the flow, creating vortices that erode material surrounding the piers or abutments.

BRI-STARS computes sediment transport as a function of shear stress, streamflow velocity, or some other variable, and then computes contraction scour according to the sediment-transport equation selected. Contraction scour is indicated by the amount of channel degradation (or aggradation) computed by the model. If bridge piers are present in the study reach, an option is available to compute local scour due to piers. Equations recommended by Richardson and Davis (1995) are available as options in the model; the Colorado State University equation was chosen for this study.

A minimization routine is available in BRISTARS that allows the model to change channel widths or altitudes after each computational time step based on the Minimum Stream Power Theory (Chang, 1988, p. 229). The theory states that "for an alluvial channel, the necessary and sufficient condition of equilibrium occurs when the stream power per unit channel length $\gamma Q S$ is a minimum subject to given constraints. Hence, an alluvial channel with water discharge $Q$ and sediment load $Q_{S}$ as independent variables tends to establish its width, depth, and slope such that $\gamma Q S$ is a minimum. Since $Q$ is a given parameter, minimum $\gamma Q S$ also means minimum channel slope $S$."

If alteration of the channel width results in lower total stream power than raising or lowering of the channel, channel adjustments are made in the lateral direction; otherwise, the adjustments are made in the vertical direction.

An option in the minimization routine of BRISTARS allows imposition of physical limitations on the amount of lateral and vertical change in a cross section if prior knowledge exists of any vertical constraints (bedrock, boulders, diversion weirs, or other anthropogenic features) or lateral constraints such as levees or riprap. A few features were noted within the study reaches but were not at the surveyed cross-section locations. To allow the model to simulate observed changes at the surveyed cross sections, no limits were imposed in the vertical or lateral directions for either study subreach.

A part of a model for Water-Surface PROfile computations (WSPRO; Shearman, 1990) has been incorporated as an option in BRI-STARS to allow analysis of sediment transport through the bridge reach under bridge-backwater conditions. Bridge backwater is the amount of backwater caused by encroachment on the flood plain by the bridge and the upstream extent of bridge-affected water-surface altitudes exceeding those of unconstricted flow. If the use of WSPRO bridgehydraulics routines is requested, the WSPRO data are prepared separately and stored in a different data file. This associated data file must comply with restrictions imposed in WSPRO. These restrictions include location of a cross section one bridge-width upstream from the bridge (approach section), a cross section at the downstream bridge opening that includes bridge geometry (bridge section), a cross section at the downstream side of the bridge that represents natural channel conditions without the bridge in place (full valley section), and a cross section one bridge-width downstream from the bridge (exit section) for use in the bridge hydraulics routines. Including the cross sections dictated by WSPRO (approach, bridge, full valley, and exit) can substantially affect the BRI-STARS computations by 
decreasing the flow length between cross sections and decreasing the amount of sediment transport during each time step of the model.

Separate input files were made for each bridge according to the limitations imposed by WSPRO. The geometry for the approach and exit cross sections was determined from $0.61-\mathrm{m}$ contour maps provided by NDOT and from data of an indirect discharge measurement at the Mesquite bridge in January 1989. Fieldsurveyed data from May 1996 were used for the bridge section.

\section{Model Calibration}

To calibrate the BRI-STARS model for use on the study reaches of the Virgin River, the hydrograph for the period of the March 12, 1995, flood was routed through the study reaches using the surveyed 1994 cross-section data as model input. The resulting cross sections were then compared with the surveyed 1995 cross sections to determine how well the model would simulate the observed changes.

Several computational options, which include selection of a sediment-transport equation, the time step, the number of sediment computations for each time step, the number of streamtubes used, and the thickness of the active layer, were evaluated to obtain the optimal combination. The optimal combination showed the best correspondence of the resulting model cross sections to the 1995 surveyed data. The sedimenttransport equations selected for each bridge reach (see section "Sediment Hydrographs") are not the equations that might be chosen on the basis of bed-material size distributions in the bridge reaches; however, the best results were obtained using these selected equations. Specifying one sediment computation for each time step was sufficient due to the relatively short time steps (1.5 and 2 hours) selected. Increasing the number of sediment computations for each time step did not improve the comparison of the resulting model cross sections with the 1995 surveyed data and also greatly increased the computational time of the model. Two streamtubes were selected for each bridge reach. Increasing the number of streamtubes did not improve the comparison of the model results with the surveyed data. The thickness of the active layer was adjusted to correspond to conditions observed during the field surveys and during the collection of bed-material samples.
Thalweg altitudes of the resulting model cross sections and of the 1995 surveyed cross sections, and the differences between them, are given in table 2 . Plots of the 1995 cross sections in relation to the resulting model cross sections are shown in appendix $A$. The thalweg altitudes for the resulting model cross sections as compared to the thalweg altitudes for the 1995 cross sections were $\pm 1 \mathrm{~m}$ at all cross sections (table 2, appen$\operatorname{dix}$ A) except cross section 3-3, which is immediately downstream from the drop structure at the Bunkerville diversion. For this cross section, the difference between model-simulated and documented (1995) scour was greater than $\pm 1 \mathrm{~m}$. This difference is because of the "unnatural" features (concrete blocks, old cars) in the channel at this cross section that reduce velocity and protect the channel bed that cannot be accounted for in the model. Although the thalweg altitudes compared reasonably well, the model results did not indicate the widening and lateral shifting of the channel that was observed in 1995 at many of the cross sections, especially in reaches 5 and 6 near the Riverside bridge. This difference is because the model does not include a mass-wasting routine and cannot account for the complex channel avulsion ${ }^{1}$ that occurred in these reaches. In summary, the comparison between the calibration results and the observed channel changes between 1994 and 1995 indicates that the model provides a good overall estimate of aggradation or degradation at the bridges.

\section{Scour Calculations for 100 - and $500-$ Year Floods}

After the model was calibrated, contraction, channel, pier, and total scour were calculated for the 100- and 500-year floods at each of the bridge sites (table 3). Bridge cross sections at the initial channelbed altitude (from 1994) and at the peak of the 100-and 500 -year floods are shown in figure 4 . The simulated scour for the 100- and 500-year floods was less than anticipated at the bridges, especially at the cross sections, on the basis of scour simulated for the lower magnitude flood of March 1995 used in the calibration process. The resulting low scour may be due to the large amount of sediment that is transported during the

\footnotetext{
${ }^{1}$ Avulsion is the process where the river cuts a new channel by shifting laterally in a rapid, somewhat random manner. Gradual lateral migration of the river is not considered avulsion.
} 
Table 2. Thalweg altitudes predicted by model and surveyed in 1995, Virgin River, Nev. and Ariz.

\begin{tabular}{|c|c|c|c|c|}
\hline \multirow{2}{*}{$\begin{array}{l}\text { Cross } \\
\text { section }\end{array}$} & \multicolumn{3}{|c|}{ Thalweg altitude (meters) } & \multirow[b]{2}{*}{ Comments } \\
\hline & Model & $\begin{array}{c}1995 \\
\text { survey }^{\mathrm{a}}\end{array}$ & Difference $^{b}$ & \\
\hline $2-1$ & 499.473 & 500.338 & -0.86 & $\begin{array}{l}\text { Model shows more scour in channel and on left- and right-bank } \\
\text { flood plains than } 1995 \text { survey. Model thalweg is in approxi- } \\
\text { mately same location as } 1995 \text { survey. Model did not show chan- } \\
\text { nel widening on right bank. }\end{array}$ \\
\hline $2-3$ & 498.228 & 499.077 & -0.85 & $\begin{array}{l}\text { Model shows more scour in channel and on left-bank flood } \\
\text { plain than } 1995 \text { survey. Model thalweg is in same position as } \\
1995 \text { survey. }\end{array}$ \\
\hline $3-1$ & 476.877 & 476.406 & +0.47 & $\begin{array}{l}\text { Similar channel geometry between model output and } 1995 \text { sur- } \\
\text { vey. Model thalweg is on right side of channel instead of left } \\
\text { side as in } 1995 \text { survey. }\end{array}$ \\
\hline $3-2$ & 476.013 & 476.719 & -0.71 & $\begin{array}{l}\text { Model shows more scour in channel and on right-bank side } \\
\text { channels than } 1995 \text { survey. Model did not show shift in thalweg } \\
\text { from left to right bank, resulting in model thalweg location on } \\
\text { left side of channel instead of on right side as in } 1995 \text { survey. }\end{array}$ \\
\hline $3-3$ & 470.796 & 473.529 & -2.73 & $\begin{array}{l}\text { Cross section about } 10 \text { meters downstream from diversion drop } \\
\text { structure. Model shows more scour than } 1995 \text { survey because } \\
\text { of flow over drop structure. } 1995 \text { survey did not have high } \\
\text { scour, probably because of large volume of stable material } \\
\text { (cars, concrete blocks) on channel bed. }\end{array}$ \\
\hline $4-1$ & 440.098 & 439.377 & +0.72 & $\begin{array}{l}\text { Model did not show as much deepening on right side of chan- } \\
\text { nel. Model thalweg is in about same location as in } 1995 \text { survey }\end{array}$ \\
\hline $4-3$ & 439.161 & 439.047 & +0.11 & $\begin{array}{l}\text { Similar channel geometry between model output and } 1995 \text { sur- } \\
\text { vey. Model showed same general trend of thalweg shifting from } \\
\text { left bank to center of channel, resulting in model thalweg loca- } \\
\text { tion in approximately same location as in } 1995 \text { survey. }\end{array}$ \\
\hline $5-1$ & 433.521 & 433.426 & +0.10 & $\begin{array}{l}\text { Channel geometry similar to } 1995 \text { survey. Model did not show } \\
\text { as much shift of channel thalweg toward left bank as } 1995 \text { sur- } \\
\text { vey, but model did show same general trends. }\end{array}$ \\
\hline $5-3$ & 432.482 & 431.473 & +1.01 & $\begin{array}{l}\text { Model did not show channel widening on left bank resulting in } \\
\text { model thalweg location on right bank instead of left bank as in } \\
1995 \text { survey. }\end{array}$ \\
\hline $5-4$ & 430.076 & 430.358 & -0.28 & $\begin{array}{l}\text { Model did not show channel widening on left and right banks } \\
\text { resulting in model thalweg location in center of channel instead } \\
\text { of on right bank as in } 1995 \text { survey. }\end{array}$ \\
\hline $6-1$ & 423.174 & 422.757 & +0.42 & $\begin{array}{l}\text { Model did not show channel widening on left bank, resulting in } \\
\text { model thalweg location on right bank instead of left bank as in } \\
1995 \text { survey. Model did show some fill in right bank channel, } \\
\text { but not as much as in } 1995 \text { survey. }\end{array}$ \\
\hline
\end{tabular}

a Thalweg altitudes were surveyed to nearest hundredth of a foot, then converted to meters.

${ }^{b}$ Difference is shown to two or three significant figures. 
Table 3. Simulated maximum contraction, channel, pier, and total scour or fill at the Mesquite and Riverside, Nev., bridges for 100 - and 500-year floods

[+, channel fill; -, channel scour $]$

\begin{tabular}{cccc}
\hline \multirow{2}{*}{ Bridge } & \multicolumn{3}{c}{ Maximum scour or fill (meters) } \\
\cline { 2 - 4 } & $\begin{array}{c}\text { Contraction } \\
\text { and channel }\end{array}$ & Pier & Total \\
\hline & 100 -year flood & \\
Mesquite, Nev. & +0.20 & -1.50 & -1.30 \\
Riverside, Nev. & -0.41 & -1.49 & -1.90 \\
& 500 -year flood & & \\
Mesquite, Nev. & +0.22 & -1.54 & -1.32 \\
Riverside, Nev. & -0.47 & -1.54 & -2.01 \\
\hline
\end{tabular}

time step in which the peak flow occurs and then is deposited in the next downstream cross section during the following time step on the hydrograph recession. Sediment in transport at high flows will not be moved any further downstream than the next downstream cross section by design of the model.

\section{ASSESSMENT OF GENERAL SCOUR}

The BRI-STARS model does not have a component to compute general scour. Therefore, other methods were used to estimate long-term aggradation or degradation of the channel. Estimation is often difficult because of the lack of long-term data. Additionally, the processes responsible for the degradation or aggradation are important to understand so they can be incorporated when designing new bridges.

\section{Stage and Discharge Relations}

One method for determining long-term degradation or aggradation is to evaluate changes in gage height through time for a given discharge. On the lower Virgin River, the Littlefield gaging station has a long period of record (1929-95). However, approximately 20 years of the gage-height data were not available. Although this gage is upstream from the bridge sites, it is the closest and has the longest period for which data are available. However, two large diversion drop structures are between the gaging station and the bridge sites. How these structures may influence general scour estimates made upstream and applied to the bridge sites is unknown.
Relations of stage, mean annual discharge, and peak discharge with time for the Littlefield gaging station are shown in figure 5. A low-flow discharge of $5.66 \mathrm{~m}^{3} / \mathrm{s}$ was chosen for this analysis ${ }^{1}$ because this flow would be confined within the channel. This analysis was repeated for a slightly higher discharge (11.33 $\mathrm{m}^{3} / \mathrm{s}$ ) with similar results. Figure 5 shows no general, long-term trend of aggradation or degradation; ${ }^{2}$ however, several cycles of aggradation and degradation occurred during 1929-95. The periods of aggradation are generally associated with periods of lower discharge; the periods of degradation are generally associated with periods of higher discharge, except for a high peak flow in 1967 that resulted in aggradation. On the basis of rating curves ${ }^{3}$ in use on October 1 of each year of record (1929-95), which have been adjusted to a common datum, the difference between highest and lowest stage for the chosen low flow $\left(5.66 \mathrm{~m}^{3} / \mathrm{s}\right)$ is 0.87 $\mathrm{m}$. This value $(0.87 \mathrm{~m})$ is the best estimate of general scour.

As shown in figure 5, approximately 20 years of gage-height data are unavailable for use in the stagedischarge analysis. However, some interpretations about what may have occurred during the period of missing data can be inferred from the streamflow statistics. A series of aggradation and degradation cycles during this period probably resulted in the $0.51 \mathrm{~m}$ of degradation between 1937 and 1959. The first major period of degradation probably was associated with the high annual mean discharge during the 1941 water year. A period of gradual aggradation probably followed during the relatively dry period of the 1940's and early 1950 's. According to the data, the highest gage height may have been in about 1950. Another period of degradation probably occurred during water year 1952 when the annual mean discharge was above average. This may have been followed by a few years of relative stability and then another period of degradation associated with higher streamflows in 1958.

${ }^{1}$ The metric value of $5.66 \mathrm{~m}^{3} / \mathrm{s}$ is equivalent to 200 cubic feet per second.

${ }^{2}$ NDOT compared bridge-construction plans and the approximate current flowline and determined that the river bed has lowered more than $2 \mathrm{~m}$ at the bridge sites (Paul Frost, NDOT, written commun., 1996). The estimated $2 \mathrm{~m}$ of scour at the bridges as reported by NDOT is due in part to contraction and local scour and, therefore, is not representative of general scour.

${ }^{3}$ Rating curves graphically relate gage height to water discharge. 
A.

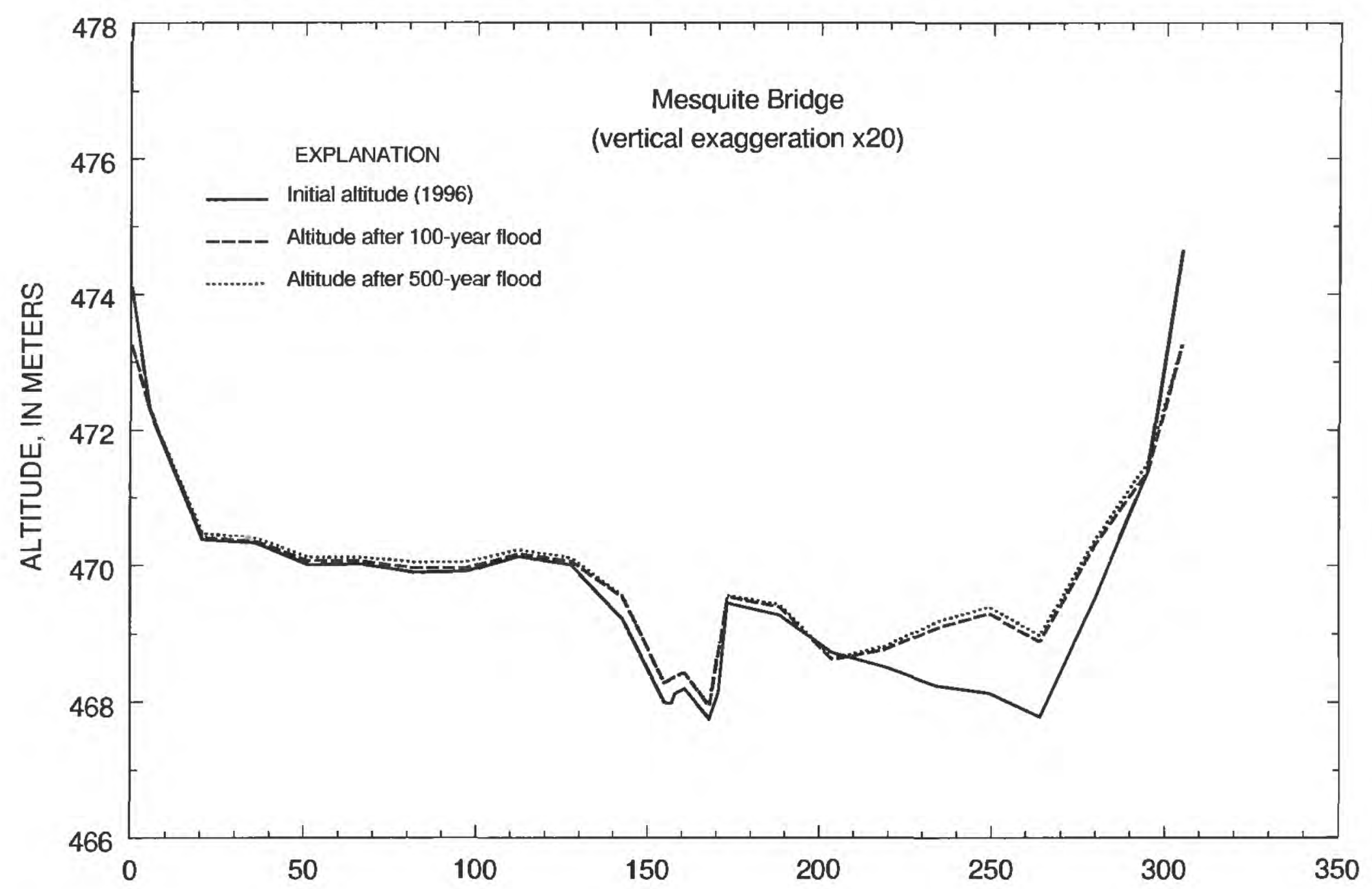

B.

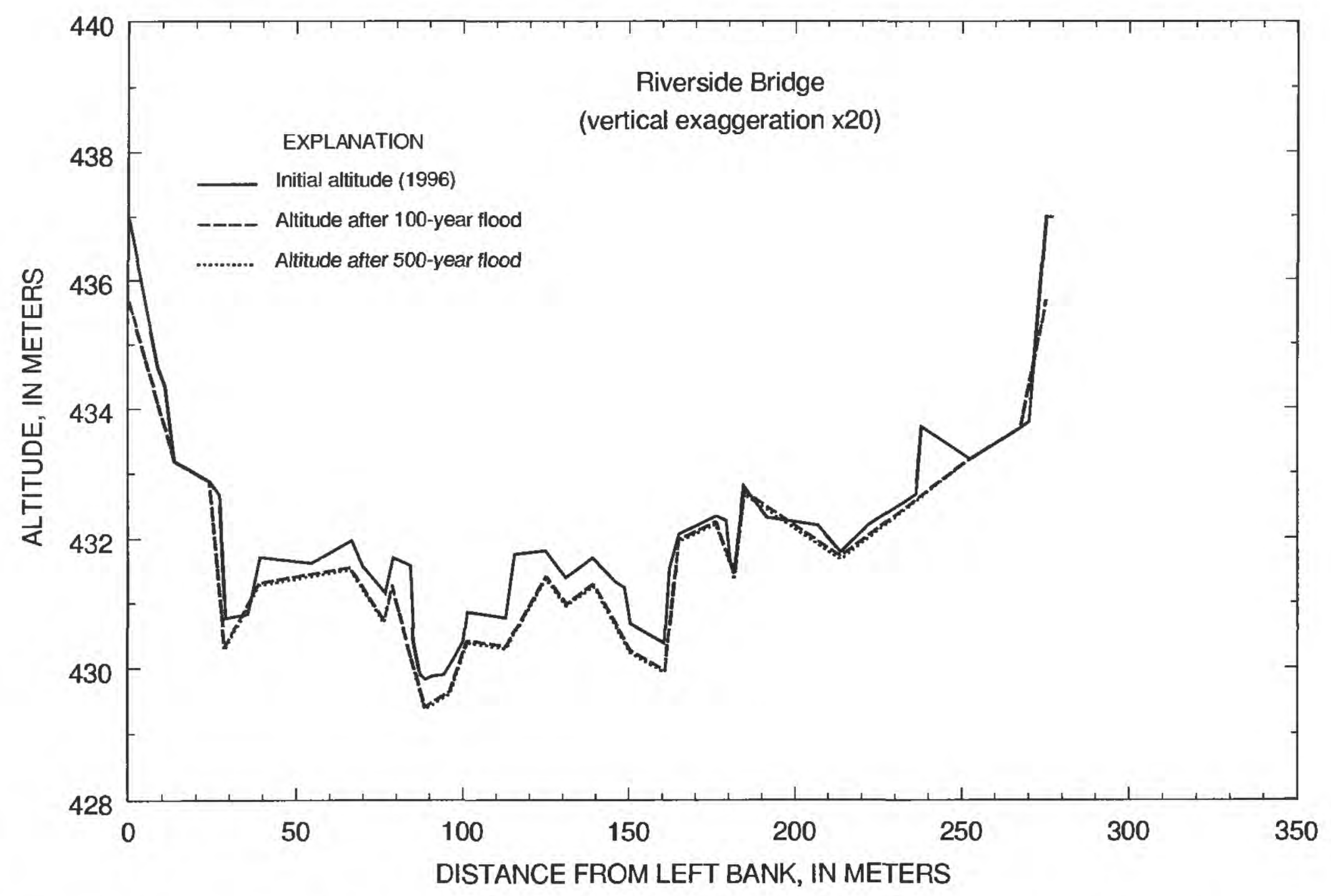

Figure 4. Cross sections of channel-bed altitude for 1996 (initial altitudes) and for peak of 100-and 500-year floods at (A) Mesquite and (B) Riverside, Nev., bridges. 


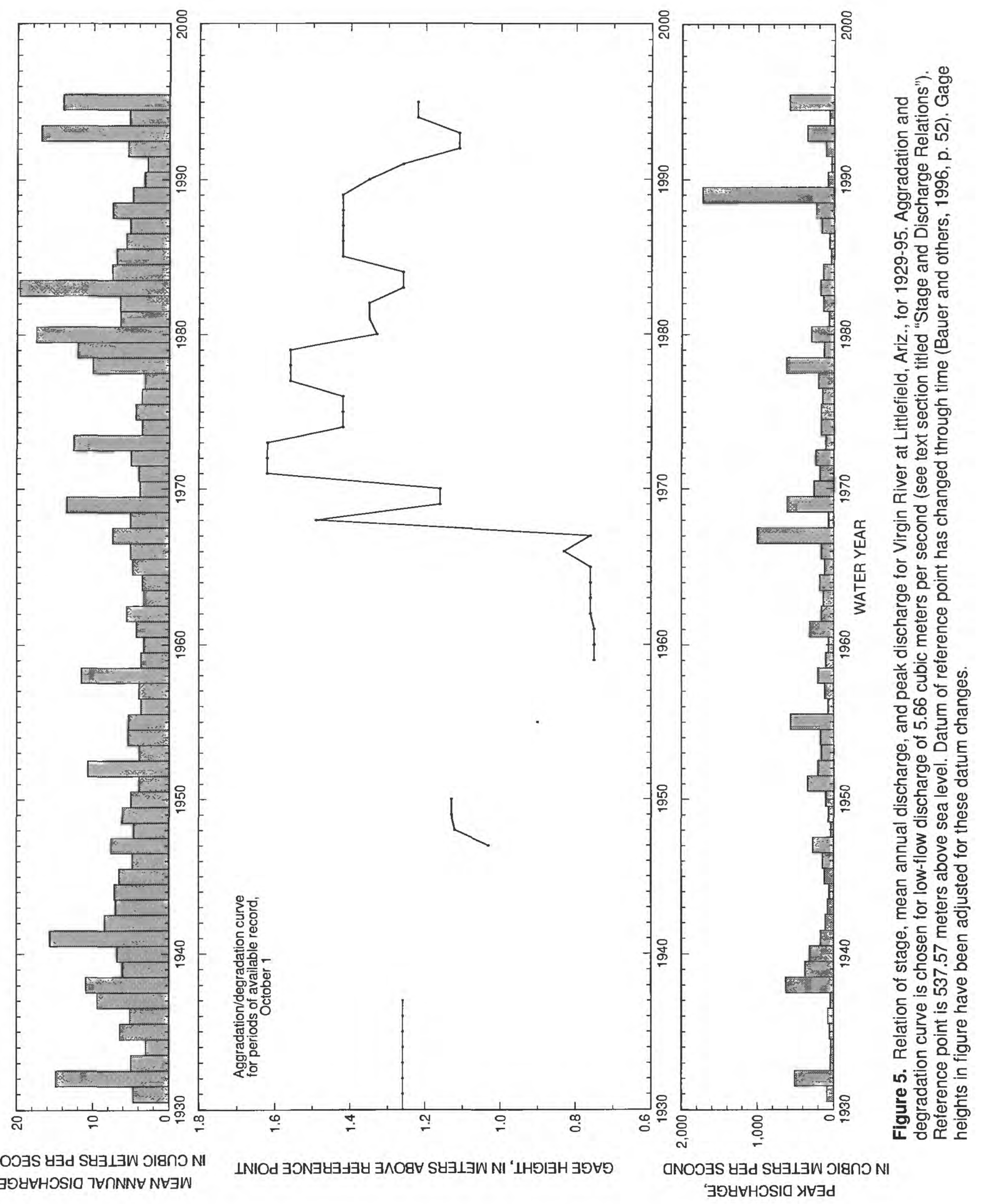


Estimates from the data indicate that the lowest gage heights of record may be associated with the degradation cycle in 1958.

\section{Channel-Geometry Data for Study Reaches}

The channel-geometry data that were collected for 1993-95 at the study reaches are relatively short term, but the data cover a large part of the river and, thus, allow for a more comprehensive understanding of changes in the system. Figures in appendix B show the cross-section altitudes for 1993, 1994, and 1995. Depth of scour as calculated from the difference between the thalweg altitudes from the survey data of 1993-95 are listed in table 4 . The average scour depth for all the cross sections was $0.07 \mathrm{~m}$ between 1993 and 1994 and $0.16 \mathrm{~m}$ between 1994 and 1995 .

The reach with the greatest amount of scour was reach 5, which is immediately upstream from the Riverside bridge. Between 1993 and 1994, all four cross sections in this reach scoured. Between 1994 and 1995, three of the four cross sections scoured, with cross section 5-2 having the largest amount of scour $(1.14 \mathrm{~m})$ of all the cross sections. The large amount of scour at cross section 5-2 was accompanied by channel widening of approximately $58 \mathrm{~m}$ on the left bank, resulting in a shift of the channel thalweg to the left bank. Some of the scour in this reach may be linked to the lateral instability of the river in this section. The instability appears due in part to the natural constriction at the downstream end of this reach, which is also the site of the Riverside bridge. No other localized causes of scour were noted.

Reach 3, upstream from the Mesquite bridge, showed relatively little scour. This reach is at the Bunkerville diversion dam. Two of the cross sections are upstream from the diversion and two are downstream. The two cross sections upstream from the dam (cross sections 3-1 and 3-2) showed more scour than those below (cross sections 3-3 and 3-4). Thus, the drop structure on the diversion dam does not have much influence on channel scour downstream.

The dynamics of the river are seen by the large variability in the scour depths within the reaches. For example, in reach 7 between 1993 and 1994, cross section 7-1 at the upstream end of the reach in a straight section was scouring $(0.24 \mathrm{~m})$, cross section $7-2$ on a meander showed only a minor amount of fill $(0.02 \mathrm{~m})$, and cross section 7-3, the most downstream cross section and also in a straight section, was filling $(0.41 \mathrm{~m})$. No field evidence suggests a localized cause for this variability.

\section{Channel-Geometry Data for Synthesized 100- and 500-Year Floods}

Another method used to gain a long-term estimate of general scour was to examine the amount of scour at the historical cross sections on the basis of the synthesized 100- and 500-year floods. Figures in appendix $\mathrm{C}$ show the initial 1994 channel geometry and the channel geometry after the 100- and 500-year floods for each of the historical cross sections. The scour depth of the thalweg for the 100- and 500-year floods is listed in table 5 .

These data show that the model simulated little scour for the 100- and 500-year floods at most of the cross sections. This is probably because of the short duration hydrograph that was used for the 100 - and 500 -year floods. This technique does not give a good estimate of general scour because the duration (days) used in the flood model was relatively short when compared with the duration (months or years) of geomorphic processes that influence long-term aggradation or degradation.

\section{GEOMORPHIC PROCESSES AFFECTING VIRGIN RIVER}

Understanding the geomorphic processes that are affecting the river is important to help explain past bridge scour and design new structures. Often, only vertical changes are examined when looking at bridge scour; however, in many rivers such as the Virgin River, lateral changes also are important because of the high mobility of the channel banks. Both lateral and vertical changes should be considered to fully understand the scour processes and to quantify channel stability.

In an attempt to gain the longest record of channel change, a variety of historical information, including aerial photography, was used to document the channel changes of the Virgin River through time. Understanding why the channel has changed is difficult. Possible causes of geomorphic change include long-term changes in streamflow, climate, sediment loads, or land use; extreme floods; vegetation encroachment on the flood plain; diversions or dams; or other anthropogenic influences. 
Table 4. Channel change for surveyed cross sections, 1993-95, Virgin River, Nev. and Ariz.

$[+$, channel fill; -, channel scour $]$

\begin{tabular}{|c|c|c|c|}
\hline $\begin{array}{l}\text { Cross } \\
\text { section }\end{array}$ & Date $^{a}$ & $\begin{array}{l}\text { Channel } \\
\text { change } \\
\text { (meters) }\end{array}$ & Comments \\
\hline \multirow[t]{2}{*}{$1-1$} & 1993-94 & -0.02 & \\
\hline & $1994-95$ & -0.54 & Approximately 1.3 meters of fill on left bank. \\
\hline \multirow[t]{2}{*}{$1-2$} & $1993-94$ & -0.07 & \\
\hline & 1994-95 & -0.16 & $\begin{array}{l}\text { Approximately } 0.8 \text { meter of fill on left bank. Right side of channel filled approxi- } \\
\text { mately } 0.3 \text { meter }\end{array}$ \\
\hline \multirow[t]{2}{*}{$1-3$} & 1993-94 & +0.03 & \\
\hline & $1994-95$ & -0.05 & Approximately 1 meter of fill on left bank. Channel widened by 1 meter on left bank. \\
\hline \multirow[t]{2}{*}{$1-4$} & 1993-94 & -0.06 & \\
\hline & 1994-95 & +0.27 & $\begin{array}{l}\text { As much as } 2 \text { meters of fill on left bank. Channel widened by approximately } 1 \text { meter } \\
\text { on left bank. }\end{array}$ \\
\hline \multirow[t]{2}{*}{$2-1$} & 1993-94 & +0.27 & Channel widened approximately 2 meters on right bank. \\
\hline & 1994-95 & +0.06 & $\begin{array}{l}\text { As much as } 1 \text { meter of fill on right bank. Channel widened approximately } 6 \text { meters } \\
\text { on right bank. }\end{array}$ \\
\hline \multirow[t]{2}{*}{$2-2$} & $1993-94$ & -0.04 & \\
\hline & $1994-95$ & -0.23 & $\begin{array}{l}\text { Channel narrowed by approximately } 2.5 \text { meters on left bank. As much as } 1.5 \text { meters } \\
\text { of fill on left bank. }\end{array}$ \\
\hline \multirow[t]{2}{*}{$2-3$} & 1993-94 & -0.48 & \\
\hline & $1994-95$ & -0.18 & Approximately 1 meter of fill on left bank in small area. \\
\hline \multirow[t]{2}{*}{$3-1$} & 1993-94 & -0.13 & \\
\hline & $1994-95$ & -0.30 & Thalweg shifted from left bank to right bank. \\
\hline \multirow[t]{2}{*}{$3-2$} & 1993-94 & -0.26 & \\
\hline & $1994-95$ & +0.19 & \\
\hline \multirow[t]{2}{*}{ 3-3 } & $1993-94$ & -0.05 & Channel narrowed by approximately 5 meters on right bank. \\
\hline & $1994-95$ & -0.08 & $\begin{array}{l}\text { Channel widened by approximately } 7 \text { meters on left bank. Several side channels on } \\
\text { right bank deepened. Thalweg shifted from left bank toward right bank. }\end{array}$ \\
\hline \multirow[t]{2}{*}{$3-4$} & $1993-94$ & -0.01 & Thalweg shifted from left bank toward right bank. \\
\hline & $1994-95$ & - & Survey data not available for 1995. \\
\hline \multirow[t]{2}{*}{$4-1$} & $1993-94$ & -0.09 & \\
\hline & $1994-95$ & -0.35 & \\
\hline \multirow[t]{2}{*}{$4-2$} & $1993-94$ & -0.41 & Channel filled approximately 0.5 meter on right side of channel. \\
\hline & $1994-95$ & -0.39 & Thalweg shifted from left bank toward right bank. \\
\hline \multirow[t]{2}{*}{$4-3$} & $1993-94$ & +0.26 & Channel filled approximately 1 meter on right side (side-channel). \\
\hline & $1994-95$ & -0.47 & Thalweg shifted from left bank to center of channel \\
\hline \multirow[t]{2}{*}{$5-1$} & $1993-94$ & - & Survey data not available for 1993. \\
\hline & $1994-95$ & -0.72 & Thalweg shifted further toward left bank. \\
\hline \multirow[t]{2}{*}{$5-2$} & $1993-94$ & -0.09 & \\
\hline & $1994-95$ & -1.14 & $\begin{array}{l}\text { Channel widened by approximately } 58 \text { meters on left bank. Thalweg shifted to new } \\
\text { channel that was cut on left bank. }\end{array}$ \\
\hline \multirow[t]{2}{*}{$5-3$} & $1993-94$ & -0.27 & \\
\hline & $1994-95$ & -0.38 & $\begin{array}{l}\text { Channel widened by approximately } 75 \text { meters on left bank. Thalweg shifted to new } \\
\text { channel that was cut on left bank. As much as } 1 \text { meter of fill in right side of channel. }\end{array}$ \\
\hline
\end{tabular}


Table 4. Channel change for surveyed cross sections, 1993-95, Virgin River, Nev., and Ariz.-Continued

\begin{tabular}{|c|c|c|c|}
\hline $\begin{array}{l}\text { Cross } \\
\text { section }\end{array}$ & Date $^{a}$ & $\begin{array}{l}\text { Channel } \\
\text { change } \\
\text { (meters) }\end{array}$ & Comments \\
\hline \multirow[t]{2}{*}{ 5-4 } & 1993-94 & -0.15 & $\begin{array}{l}\text { Channel shifted approximately } 50 \text { meters toward left bank. Thalweg shifted to new channel on } \\
\text { left bank. }\end{array}$ \\
\hline & $1994-95$ & +0.04 & Channel widened by approximately 70 meters on right bank and 30 meters on left bank. \\
\hline \multirow[t]{2}{*}{$6-1$} & $1993-94$ & +0.03 & \\
\hline & $1994-95$ & +0.07 & $\begin{array}{l}\text { Channel shifted approximately } 55 \text { meters to left. Former } 1994 \text { channel filled with approximately } \\
1.2 \text { meters of sediment. }\end{array}$ \\
\hline \multirow[t]{2}{*}{$6-2$} & $1993-94$ & -0.20 & Bar in center of channel increased in height by approximately 1 meter. \\
\hline & $1994-95$ & +0.50 & $\begin{array}{l}\text { Channel shifted approximately } 95 \text { meters to left. Former } 1994 \text { channel filled with approximately } \\
2 \text { meters of sediment. }\end{array}$ \\
\hline \multirow[t]{2}{*}{$7-1$} & $1993-94$ & -0.24 & Channel widened by 13 meters on right bank. \\
\hline & 1994-95 & +0.18 & Channel narrowed by approximately 9 meters on right bank. \\
\hline \multirow[t]{2}{*}{$7-2$} & $1993-94$ & +0.02 & Thalweg moved from left bank to center of channel. \\
\hline & $1994-95$ & +0.05 & $\begin{array}{l}\text { High-flow meander on right bank filled by up to } 1 \text { meter of sediment. Thalweg shifted from cen- } \\
\text { ter toward right bank. Center of } 1994 \text { channel filled with approximately } 0.5 \text { meter of sediment. }\end{array}$ \\
\hline \multirow[t]{2}{*}{$7-3$} & $1993-94$ & +0.41 & \\
\hline & $1994-95$ & +0.08 & $\begin{array}{l}\text { Channel widened approximately } 5 \text { meters on left bank. Thalweg shifted from center of channel } \\
\text { to left bank. }\end{array}$ \\
\hline
\end{tabular}

a 1993 survey was made during November and December; 1994 and 1995 surveys were made during November.

Table 5. Depth of scour or fill calculated from model for 100- and 500-year floods, Virgin River, Nev. and Ariz.

[+, channel fill: -, channel scour]

\begin{tabular}{|c|c|c|}
\hline \multirow{2}{*}{$\begin{array}{l}\text { Cross } \\
\text { section }\end{array}$} & \multicolumn{2}{|c|}{$\begin{array}{l}\text { Simulated scour depth } \\
\text { (meters) }\end{array}$} \\
\hline & 100 -year flood & 500 -year flood \\
\hline $2-1$ & -0.01 & -0.41 \\
\hline $2-3$ & .00 & -1.04 \\
\hline $3-1$ & .00 & -.04 \\
\hline $3-2$ & .00 & -.58 \\
\hline $3-3$ & +.30 & -.48 \\
\hline $4-1$ & +.22 & -.02 \\
\hline $4-3$ & -.21 & -.23 \\
\hline $5-1$ & -.24 & -.22 \\
\hline $5-3$ & +.19 & +.22 \\
\hline $5-4$ & +.16 & +.17 \\
\hline $6-1$ & +.34 & +.35 \\
\hline
\end{tabular}

\section{Historical Perspectives}

Historical documents, including diary and journal entries, cadastral surveys, ${ }^{1}$ and early ground photographs, are the first records of channel characteristics. These resources provide only fairly general information related to channel characteristics, but they do extend the information time-frame. These general descriptions of channel characteristics can be used to infer some geomorphic processes.

Early explorers who described the lower Virgin River include Jedediah Smith, John C. Fremont, William Henry Jackson, and Lieutenant George M. Wheeler. In 1826, Jedediah Smith briefly described the lower Virgin River as being muddy and a little brackish (Fletcher, 1980). In May 1844, John C. Fremont camped near present day Littlefield, Ariz., and described the river in more detail:

The most dreary river I have ever seena deep rapid stream, almost a torrent, passing swiftly by, and roaring against obstructions (Fletcher, 1980).

\footnotetext{
${ }^{1}$ Cadastral surveys are the original land surveys used for defining property boundaries.
} 
Fremont visited the area in May and probably observed the river during snowmelt runoff. His description suggests that velocities were fast and the river was probably transporting a lot of sediment (as suggested by his use of "dreary").

In January 1867, William Henry Jackson, the well-known western photographer, wrote in his journal describing the area near Littlefield, Ariz., at the confluence of Beaver Dam Wash and the Virgin River:

Went down Beaver Dam about a mile until we struck the Rio Virgin, a swift turbid \& very red stream. *** Sand deep \& rolling very hard. $* * *$ Found a great plenty of dry mesquite wood (Hafen and Hafen, 1959).

Unfortunately, Jackson did not photograph the lower Virgin River. His description suggests that a great deal of sediment was being transported. In addition, the description implies the dominant vegetation was mesquite and not tamarisk as it is today.

A few years later, in 1869, Lieutenant George M. Wheeler, on a reconnaissance of southern Nevada, described the lower Virgin River near the confluence of the Muddy River (before Lake Mead) as:

Its sandy bed, widened by each successive freshet [flood], changeable on account of quicksands, carries its channel now to the one, now to the other side with a tortuous elasticity, and most of the crossings are uncertain because of changes in the banks and beds of quicksand (Wheeler and Lockwood, 1875). Wheeler's description suggests that in 1869 the river was dynamic with many channel changes, especially channel widening, occurring as the result of floods. On the basis of his description, the channel was tightly meandering, possibly similar to the planform of the river today in some areas. The quicksand banks Wheeler described suggest saturation similar to visual observations made after the series of winter floods in 1995.

Early land surveys of the Virgin River were done in 1881 by the General Land Office. Descriptions of the vegetation and measurements of channel width and bank height were obtained from the field notes. Vegetation mentioned included cottonwood, mesquite, branch grass, greasewood, and willow. Measurements of the channel width varied considerably, but in some places it was noted as being more than $305 \mathrm{~m}$ wide. Compare this to the widest areas today at approximately $200-230 \mathrm{~m}$. Directly comparing measurements of channel width and bank height from these notes to present conditions is difficult because little detail was given as to what was considered part of the channel and what was considered the top of bank. In addition, the accuracy of some of these early surveys is questionable. A survey done in 1912-13 of the area near the Nevada-Arizona border appears to be more accurate and detailed than the 1881 survey. The channel in the 1912-13 survey was in some places twice as wide as at present. Vegetation in the 1912-13 survey was similar to that noted in 1881 .

Ground photographs were obtained for the Mesquite and Riverside bridges that pre-date the available aerial photography. Figure $6 A$ was taken in 1924 at the Mesquite bridge. The bridge shown pre-dates the current bridge and was slightly upstream. At that time, the channel was wide and shallow. A 1996 photograph

(fig. $6 \mathrm{~B}$ ) shows a decrease in channel width, an increase in the amount of vegetation on the flood plain, and an increase in urban development. The current bridge at Mesquite was completed in 1931.

Figure $7 A$ is a pre-1932 view of the bridge at Riverside, Nev. A flood in 1932 destroyed this bridge. Figure $7 B$ is a photograph in 1996 showing the present bridge at the same site. Comparing these two photographs shows a decrease in channel width and an increase in the amount of vegetation.

\section{Observed Channel Changes Using Aerial Photography}

Examination of aerial photography is one of the best ways to document long-term channel changes. A series of aerial photographs and digital images was examined for the two bridge sites (table 6). The earliest photographs date to 1938; the most recent were from June 1995 . Thus, they provide nearly 60 years of information.

\section{Mesquite Bridge}

The first known aerial photograph for the Mesquite bridge is from 1938 (fig. $8 \mathrm{~A}$ ) and shows a braided, wide, shallow channel that spanned the entire bridge opening. Large, unvegetated bars were adjacent to the channel and little vegetation was on the rest of the flood plain. Extensive agriculture was across the entire valley, except in the active flood plain. By 1953 (fig. 8B), the channel had narrowed to approximately one-third of the bridge width and was less braided. Vegetation on the flood plain had become dense. Comparing aerial 

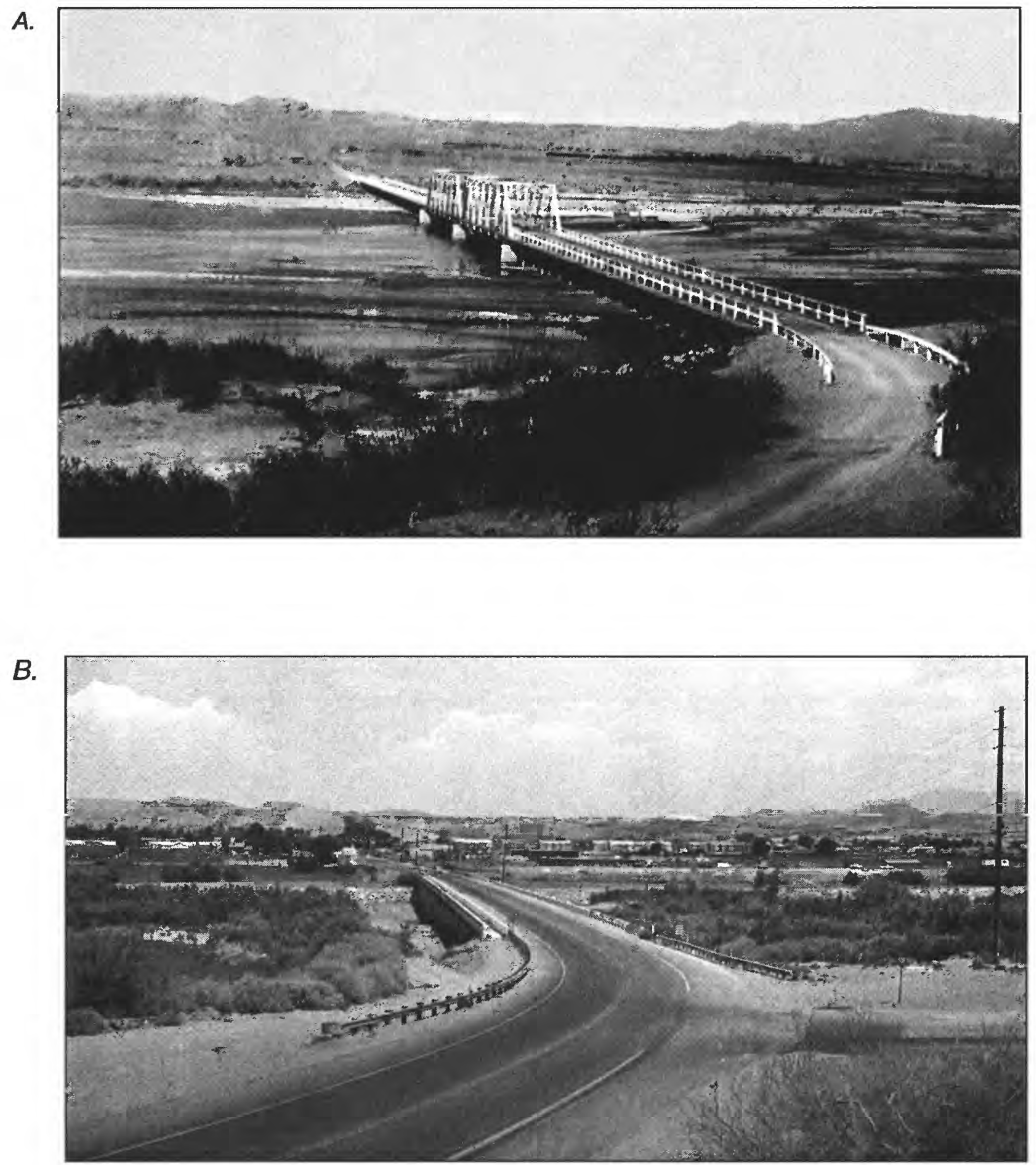

Figure 6. Views of Mesquite, Nev., bridge in (A) 1924 (photograph courtesy of Nevada Historical Society, Clark County photograph 7) and (B) 1996. View is from left bank looking northeast toward town of Mesquite. Streamflow is from right to left. 

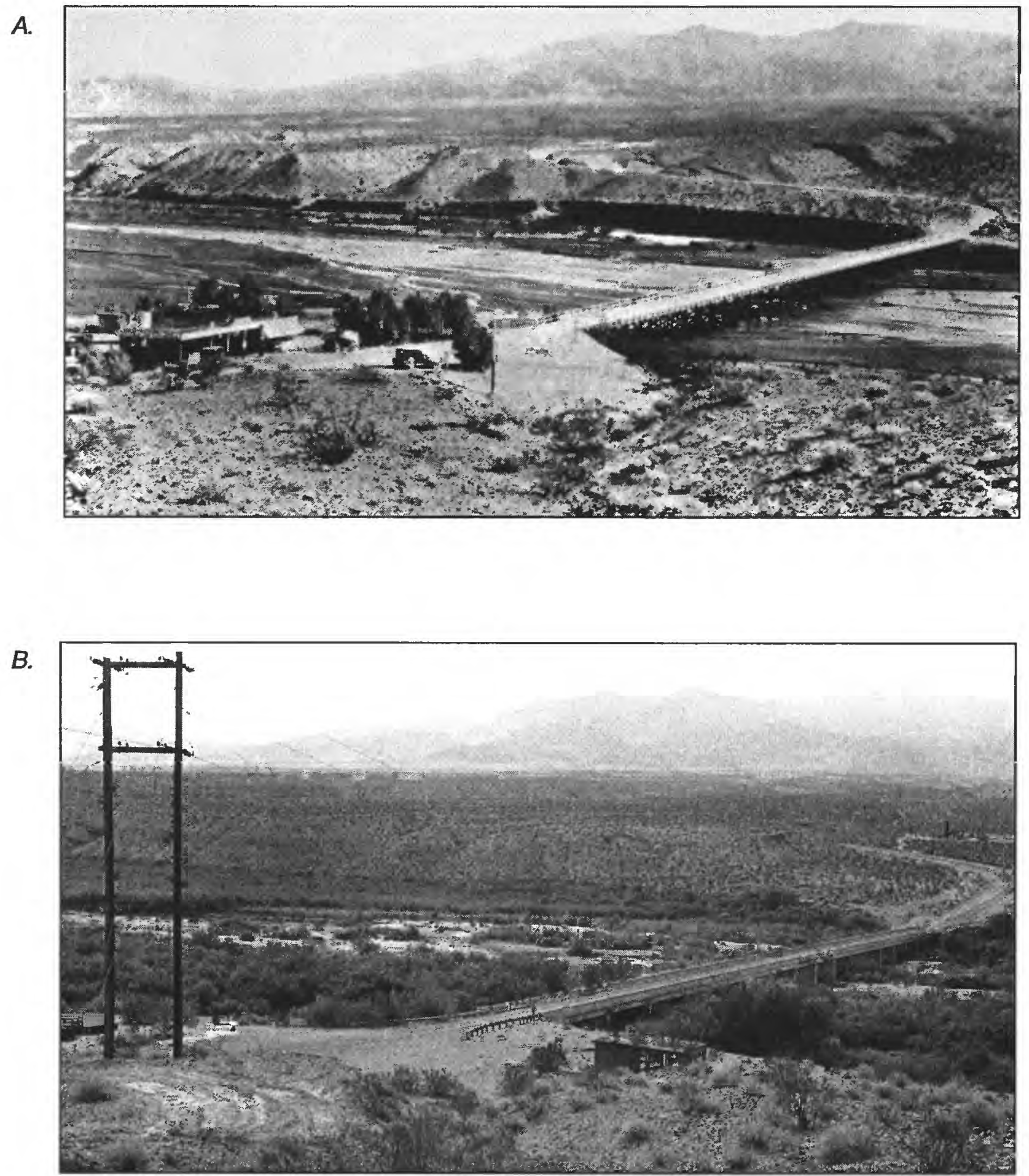

Figure 7. Views of Riverside, Nev., bridge (A) circa late 1920's (photograph courtesy of Nevada Historical Society, Clark County photograph 371 ), and (B) in 1996. View is from right bank looking southeast. Streamflow is from left to right. 
Table 6. Inventory of digital imagery and aerial photography used for study of Virgin River, Nev. and Ariz.

\begin{tabular}{|c|c|c|c|c|c|}
\hline Survey or program name & Date(s) of acquisition & $\begin{array}{l}\text { Scale or } \\
\text { resolution }\end{array}$ & Type of imagery & $\begin{array}{c}\text { Mesquite } \\
\text { bridge }\end{array}$ & $\begin{array}{c}\text { Riverside } \\
\text { bridge }\end{array}$ \\
\hline Soil Conservation Service (BPD) & November 13-21, 1938 & $1: 20,000$ & Black and white & $\mathrm{X}$ & $\mathrm{X}$ \\
\hline Army Mapping Service & $\begin{array}{l}\text { October } 14,1952- \\
\text { February } 24,1954\end{array}$ & $1: 63,000$ & Black and white & $\mathrm{X}$ & $\mathrm{X}$ \\
\hline Arizona Department of Transportation & January 28, 1964 & $1: 24,000$ & Black and white & ${ }^{\mathrm{a} X}$ & \\
\hline Nevada Highway Department & June 3, 1966 & $1: 11,244$ & Black and white & ${ }^{\mathrm{a}} \mathrm{X}$ & \\
\hline Nevada Department of Transportation (798) & April 21, 1971 & $1: 12,000$ & Black and white & ${ }^{\mathrm{a}} \mathrm{X}$ & \\
\hline Agricultural Soil Conservation Service & July 2,1973 & $1: 40,000$ & Black and white & $\mathrm{X}$ & $\mathrm{X}$ \\
\hline Arizona Department of Transportation & May 30,1975 & $1: 24,000$ & Black and white & ${ }^{\mathrm{a} X}$ & \\
\hline Bureau of Land Management (AS) & June 15,1976 & $1: 31,680$ & Natural color & $\mathrm{X}$ & $\mathrm{X}$ \\
\hline Bureau of Reclamation & April 20, 1977 & $1: 12,000$ & Black and white & $\mathrm{X}$ & $\mathrm{x}$ \\
\hline Air Force (CSR) & September 22, 1978 & $1: 25,000$ & Black and white & $\mathrm{x}$ & $\mathrm{X}$ \\
\hline High Altitude Photography (HAP) & October 4, 1980 & $1: 58,000$ & Color infrared & $\mathrm{X}$ & $\mathrm{X}$ \\
\hline Nevada Department of Transportation (1469) & October 14,1981 & $1: 3,000$ & Black and white & $\mathrm{X}$ & \\
\hline Nevada Department of Transportation (1545) & February 9,1983 & $1: 12,000$ & Black and white & $\mathrm{X}$ & \\
\hline Landsat Thematic Mapper & April 13, 1984 & $b_{30}$ meters & Digital scanner & $\mathrm{X}$ & $\mathrm{x}$ \\
\hline Nevada Department of Transportation (1420) & September 2, 1984 & $1: 66,000$ & Black and white & $x$ & $X$ \\
\hline Arizona Department of Transportation & May 16,1985 & $1: 24,000$ & Black and white & ${ }^{\mathrm{a}} \mathrm{X}$ & \\
\hline Bureau of Reclamation & July 7,1986 & $1: 6,000$ & Natural color & & $\mathrm{x}$ \\
\hline Side-Looking Airborne Radar & April - May 1987 & ${ }^{\mathrm{b}} 12$ meters & Digital scanner & $\mathrm{x}$ & $\mathrm{x}$ \\
\hline Landsat Thematic Mapper & May 10, 1988 & $\mathrm{~b}_{30}$ meters & Digital scanner & $\mathrm{X}$ & $\mathrm{x}$ \\
\hline Landsat Thematic Mapper & April 11, 1989 & $\mathrm{~b}_{30}$ meters & Digital scanner & $\mathrm{x}$ & $\mathrm{x}$ \\
\hline Nevada Department of Transportation (2052) & April 27, 1990 & $1: 3,000$ & Black and white & & $\mathrm{x}$ \\
\hline National Aerial Photography Program & $\begin{array}{l}\text { February } 24 \text { - } \\
\text { August } 28,1992\end{array}$ & $1: 40,000$ & Black and white & $\mathrm{X}$ & \\
\hline Arizona Department of Transportation & October 15,1992 & $1: 24,000$ & Black and white & ${ }^{\mathrm{a}} \mathrm{X}$ & \\
\hline Nevada Department of Transportaion(2242) & March 14, 1994 & $1: 3,000$ & Black and white & & $\mathrm{X}$ \\
\hline U.S. Geological Survey (Kenney Aerial Mapping) & June 1, 1994 & $1: 24,000$ & Color infrared & $\mathrm{X}$ & $\mathrm{X}$ \\
\hline Nevada Department of Transportation (2303) & March 16, 1995 & $1: 6,000$ & Black and white & $\mathrm{X}$ & $\mathrm{x}$ \\
\hline U.S. Geological Survey (Kenney Aerial Mapping) & August 8, 1995 & $1: 24,000$ & Color infrared & $\mathrm{X}$ & $\mathrm{X}$ \\
\hline
\end{tabular}

${ }^{\text {a }}$ Photographs do not include bridge, but are for area near bridge site.

${ }^{b}$ Resolution of digital image.

photographs taken in 1964 with those taken in 1966 (not shown in fig. 8) for an area upstream from the bridge shows that a meander on the right bank was cut off and the channel was straight downstream from the Bunkerville diversion. This straight channel appears to be the result of natural channel avulsion, probably the result of a series of floods during November and December 1965, and not due to channelization associated with the diversion. Upstream from the diversion, the channel was meandering in 1966. The Bunkerville diversion structure was first built when the town of Bunkerville was settled in the late 1870's. The diversion structure was replaced many times because it was frequently destroyed by floods (Larson, 1961). In 1957, the Soil Conservation Service completed the permanent structure at the present site.
By the early 1970's, agriculture had increased on the right bank downstream from the bridge. Sewage treatment ponds had been built on the right bank, immediately upstream from the bridge. Both the increase in agriculture and the construction of the treatment ponds encroached on the flood plain and further confined the channel as it went through the bridge. At this time, the channel was relatively straight with some braiding. During 1976 to 1977 , a distinct lowflow channel had formed and was relatively straight approaching the bridge. This low-flow channel spanned approximately one-eighth of the bridge. Prominent channel banks had formed, indicating vertical scour. In 1978, additional treatment ponds were built upstream from the bridge extending further into the flood plain (fig. $8 \mathrm{C}$ ), further constricting the channel 
A.

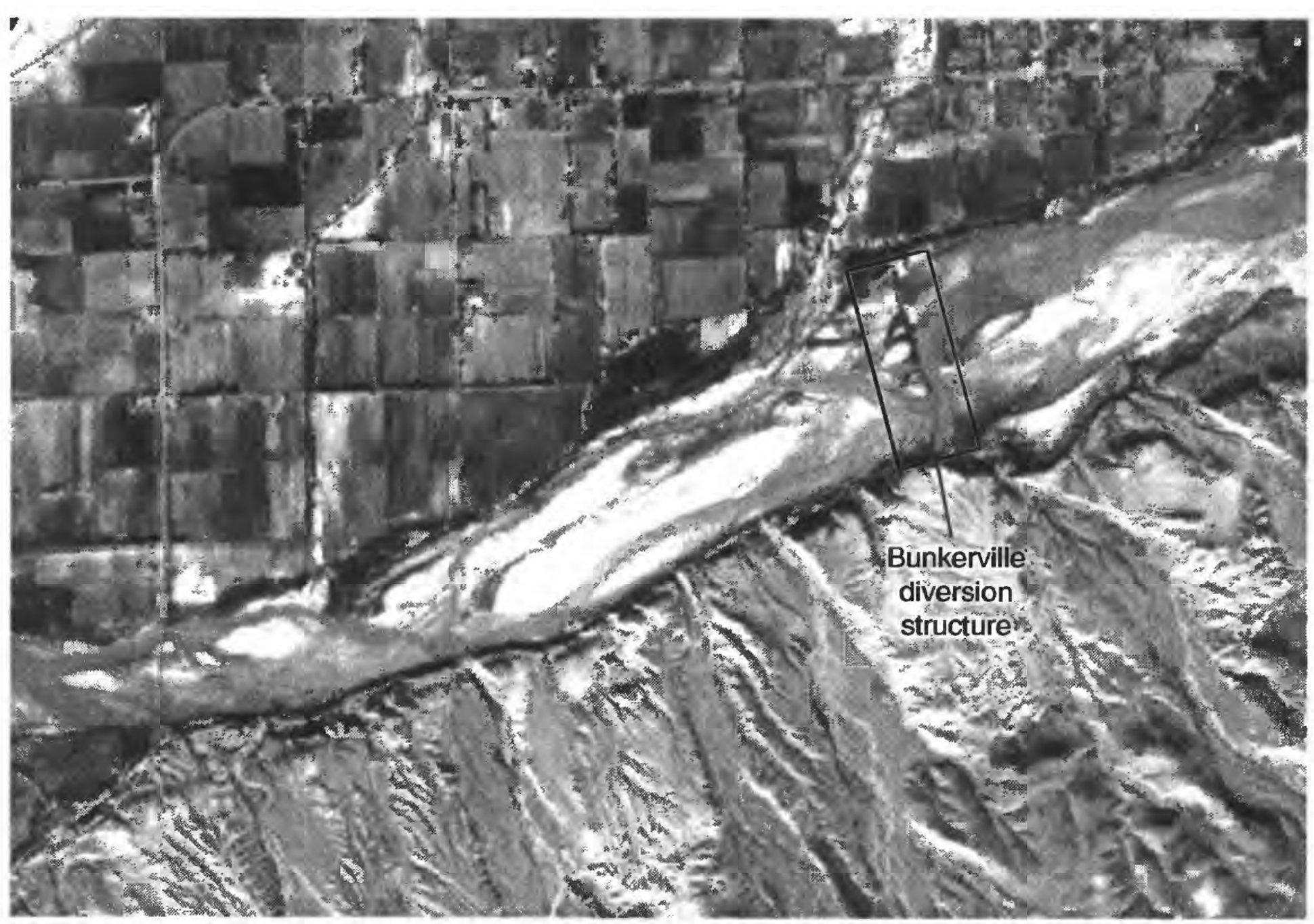

$B$.
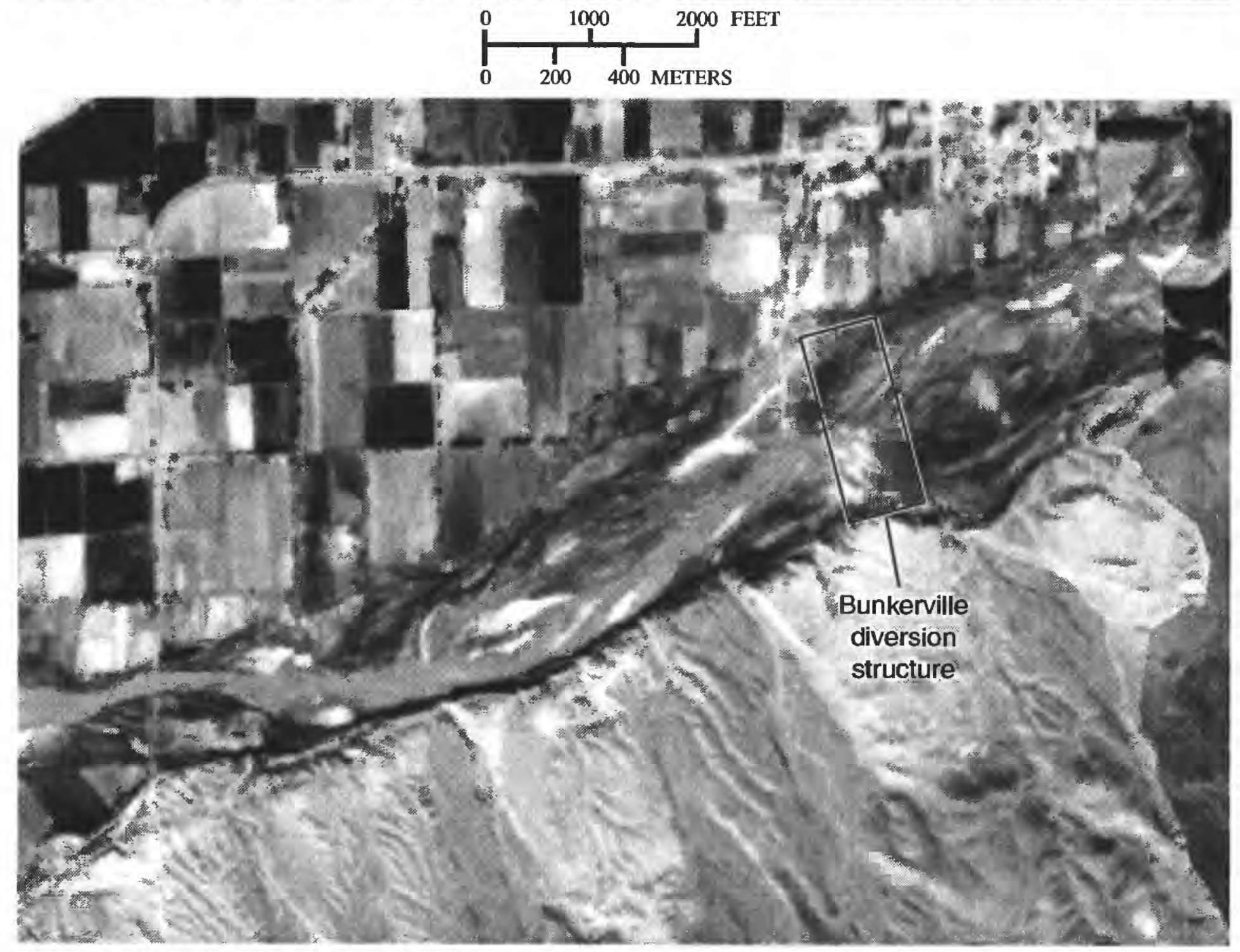

Figure 8. Aerial photographs of Mesquite, Nev., bridge area (A) November 13, 1938 (Soil Conservation Service), (B) February 24, 1954 (Army Mapping Service), (C) September 22, 1978 (U.S. Air Force), and (D) August 8, 1995 (U.S. Geological Survey). Photographs are oriented with north at top and streamflow is from right to left. Figures $8 B-D$ are mosaics of two photographs. 
C.

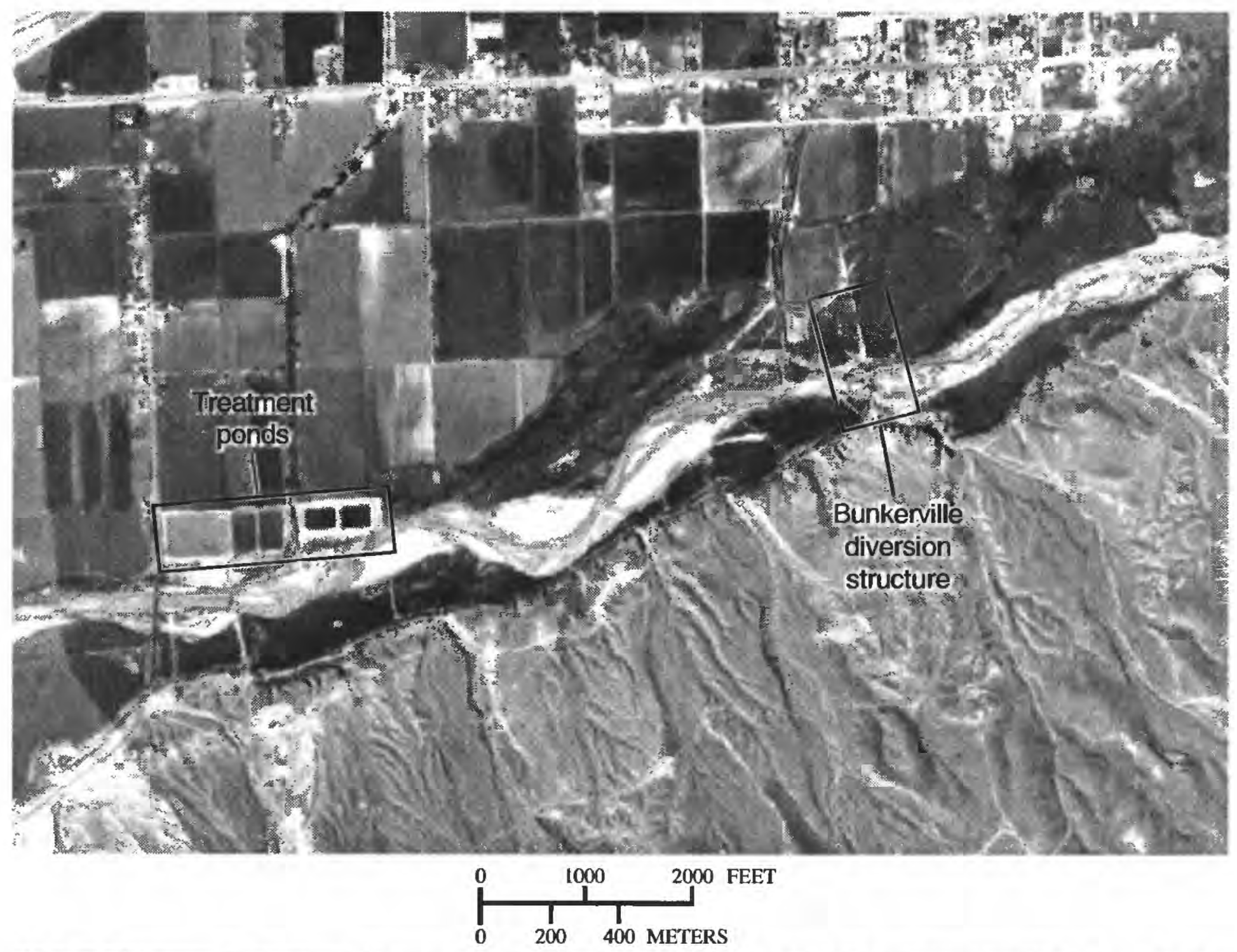

$D$.

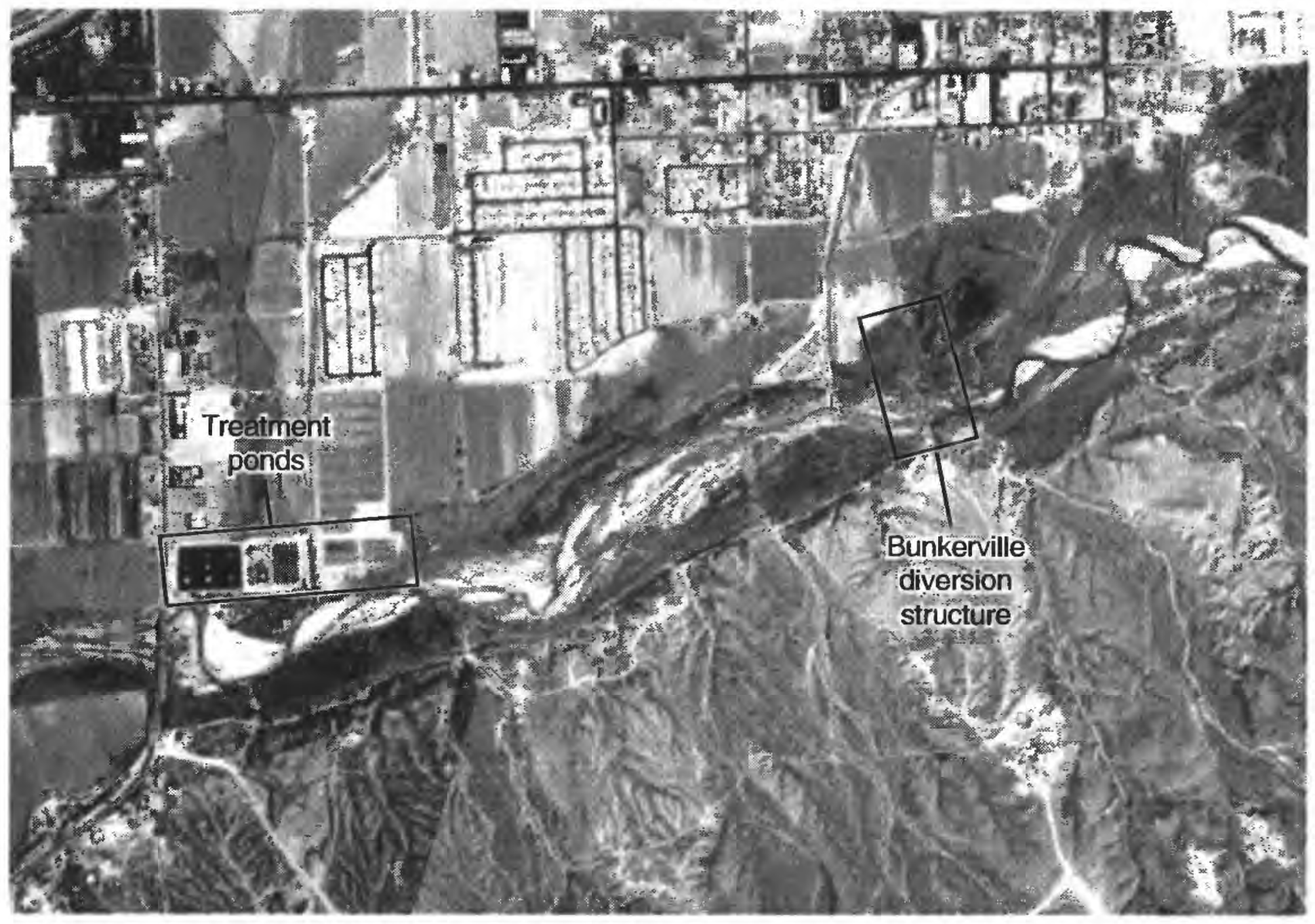

Figure 8. Continued. 
upstream from the bridge. A meander formed on the upstream edge of the treatment ponds and the channel widened and became more sinuous. Vegetation continued to become dense and occupy more of the flood plain.

In the early 1980's, the channel upstream and downstream from the bridge shifted laterally several times and became more sinuous. However, near the bridge, the channel was confined not only by the bridge but also by development on the right bank flood plain, which restricted the river from meandering as much as in areas where the channel was not confined. In this confined zone, the valley width available for the channel to migrate across was approximately one-quarter of the width of the valley upstream and downstream. By the 1990's, the channel had become dramatically narrower (fig. $8 D$ ) with vegetation covering any area that was not part of the active channel. Also, by the early 1990's, the right-bank flood plain changed from agricultural to urban use. In 1993 and 1995, migration and avulsion of the channel increased in the unconfined areas of the valley upstream from the Bunkerville diversion and downstream from the Mesquite bridge. In the confined area near the bridge, a meander formed immediately upstream and threatened the treatment ponds. Channelization was done after the flood of March 1995; the channel was straightened through the bridge opening in an attempt to save the treatment ponds. In May 1996, a bank stabilization project, which included filling and riprapping of the right bank, was completed at the bridge.

The angle of attack on the bridge piers, which can be measured from the aerial photographs (table 7), has changed through time. From 1938-77, the angle of attack was fairly constant at 10-17 degrees southwest. An exception was in 1973, when the angle was 15 degrees northwest because a mid-channel bar had formed. In the late 1970's and early 1980's, the channel was relatively straight and was not attacking the piers at an angle. The 1990's showed an increase in the angle of attack primarily because of the meander that had formed upstream from the bridge.

\section{Riverside Bridge}

The first known aerial photograph for the Riverside bridge was from 1938 (fig. 9A). The valley is wide upstream from the bridge and narrows below the bridge (to approximately one-quarter of the upstream width) as a result of a natural constriction. At that time, the river was broadly meandering and was wide and
Table 7. Flow angle of attack on Mesquite and Riverside, Nev., bridges as measured from aerial photographs

[Angle of attack is measured from a line perpendicular to bridge orientation, not true north. SW, southwest; NW, northwest; - , photograph not available].

\begin{tabular}{crr}
\hline Date of aerlal & \multicolumn{2}{c}{ Angle of attack on bridge (degrees) } \\
\cline { 2 - 3 } photograph & Mesquite & Riverside \\
\hline 1938 & $10 \mathrm{SW}$ & $45 \mathrm{SW}$ \\
1952 & $15 \mathrm{SW}$ & -- \\
1953 & -- & $49 \mathrm{SW}$ \\
1954 & $15 \mathrm{SW}$ & - \\
1971 & $17 \mathrm{SW}$ & - \\
1973 & $15 \mathrm{NW}$ & $10 \mathrm{SW}$ \\
1976 & $13 \mathrm{SW}$ & $20 \mathrm{NW}$ \\
1977 & $17 \mathrm{SW}$ & $15 \mathrm{SW}$ \\
1978 & $7 \mathrm{SW}$ & $1 \mathrm{NW}$ \\
1980 & 0 & $5 \mathrm{SW}$ \\
1981 & 0 & - \\
1983 & 0 & -- \\
1984 & 0 & $5 \mathrm{NW}$ \\
1986 & -- & 0 \\
1987 & -- & $25 \mathrm{NW}$ \\
1990 & -- & 0 \\
1992 & $40 \mathrm{SW}$ & -- \\
1994 & $26 \mathrm{SW}$ & 0 \\
1995 & $43 \mathrm{SW}$ & $5 \mathrm{NW}$ \\
\hline
\end{tabular}

shallow, with the width of the river spanning the entire bridge opening. The natural constriction was enhanced by the bridge further constricting the channel. In 1938, several unvegetated bars were adjacent to the channel. Agricultural development was not on the flood plain at that time. By 1953 (fig. 9B), the channel had narrowed and spanned only two-thirds of the bridge width. Vegetation had become dense on the flood plain and agricultural areas on the left bank immediately downstream from the bridge and in a small area upstream from the bridge further constricted the channel.

Several changes occurred between 1953 and 1973. Several large meanders formed upstream from the bridge and two meanders had been cut off, decreasing the sinuosity of the river. The timing of these changes is unknown, but multiple floods during the period may have been responsible as indicated by the differences in vegetation density in the abandoned meanders. The agricultural area seen in 1953 upstream from the bridge was gone by 1973 . By 1978 (fig. 9C), the channel had widened in several places and several of the meanders had changed shape 
A.

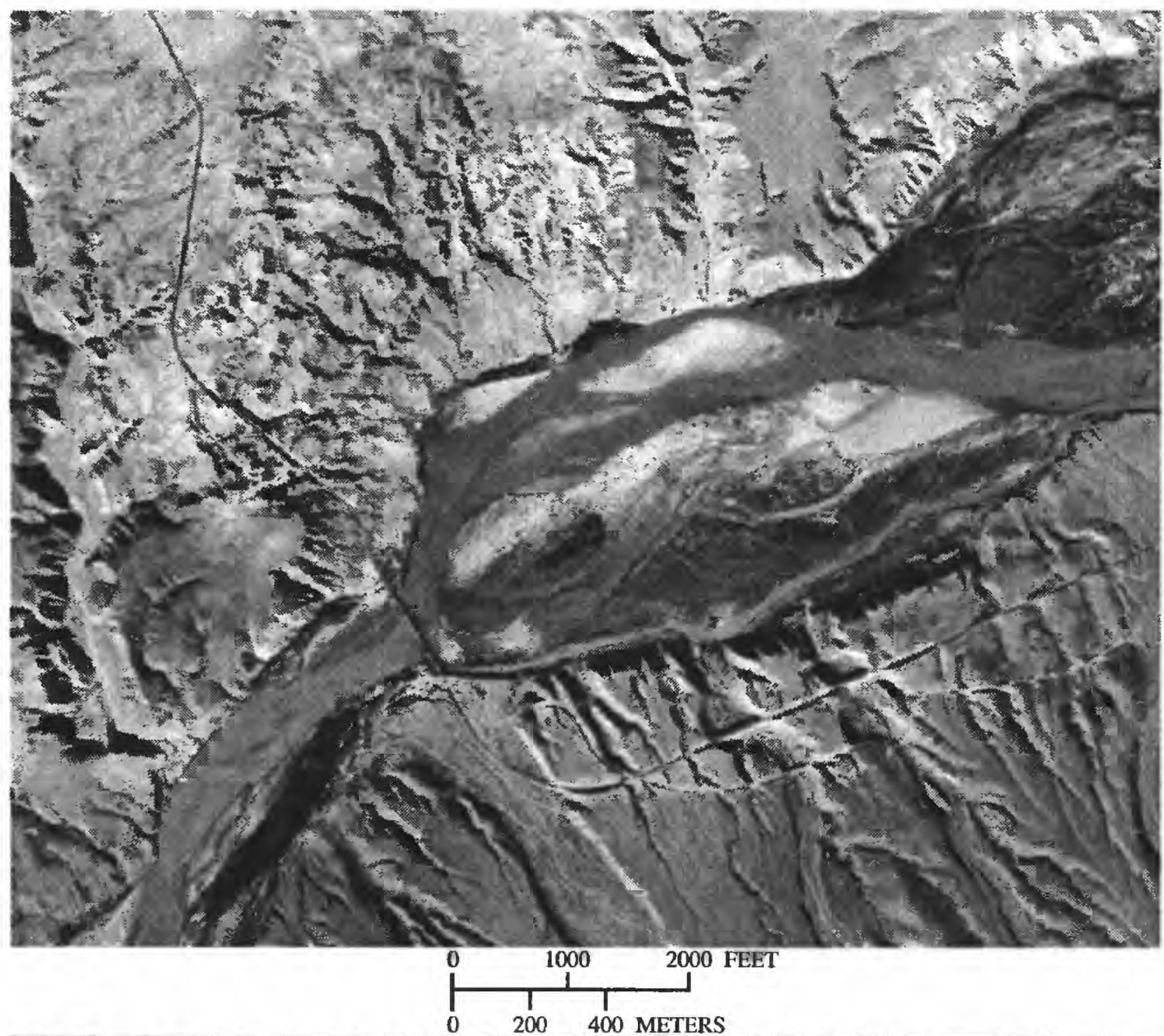

$B$.

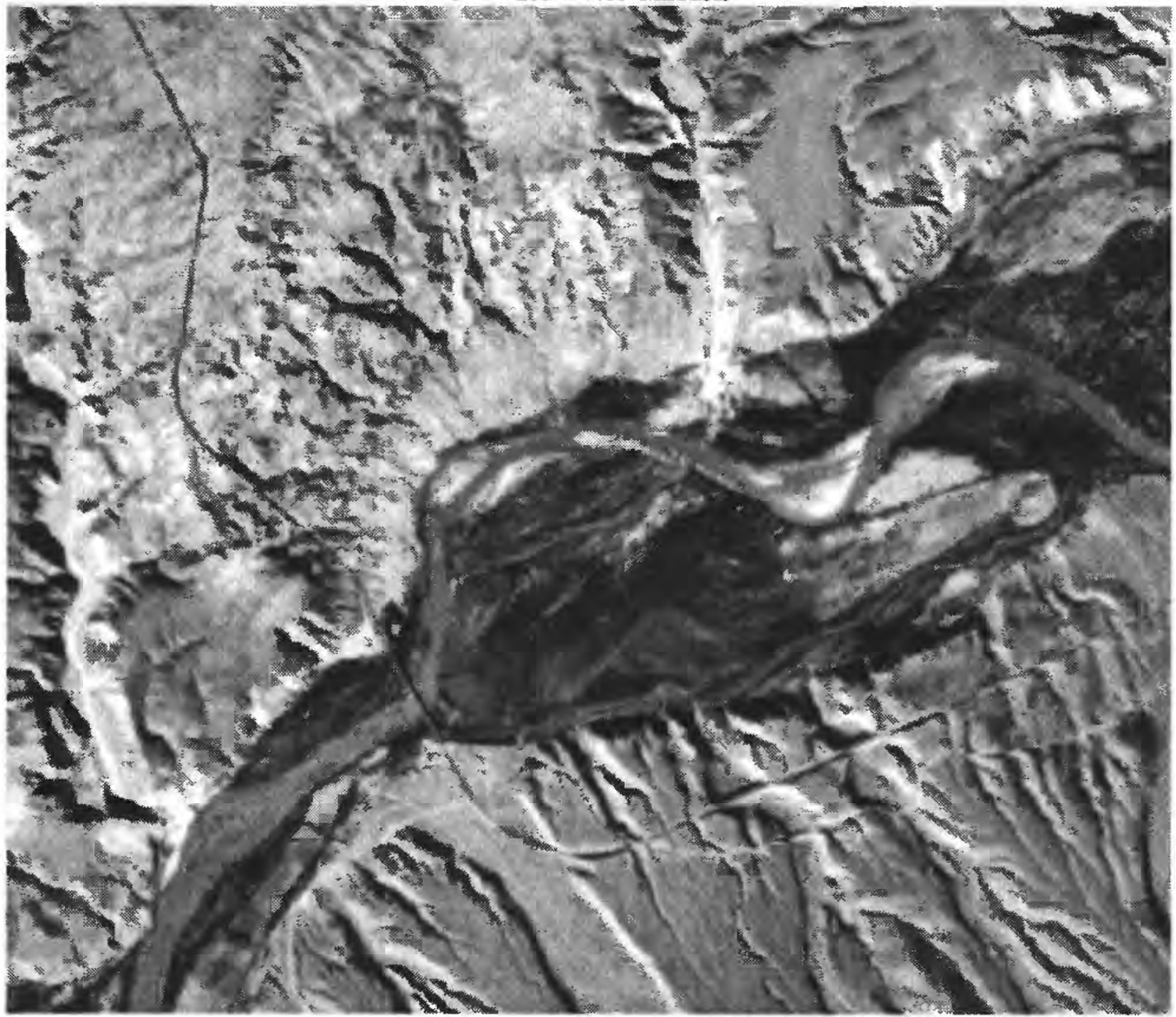

Figure 9. Aerial photographs of Riverside, Nev., bridge area (A) November 13, 1938 (Soil

Conservation Service), (B) November 16, 1953 (Army Mapping Service), (C) September 22, 1978 (U.S. Air Force), and (D) August 8, 1995 (U.S. Geological Survey). Photographs are oriented with north at top and streamflow is from right to left. 
C.

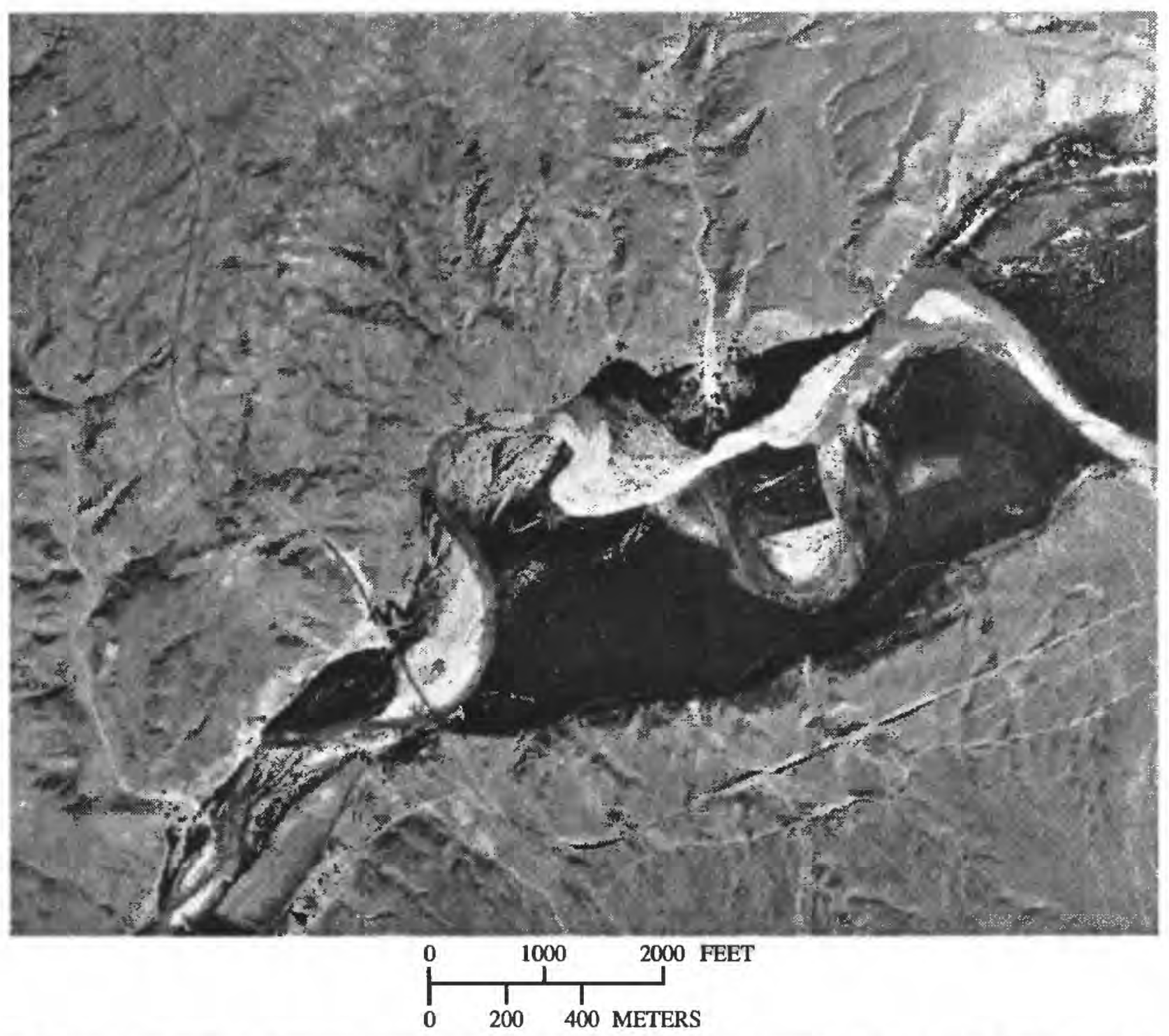

D.

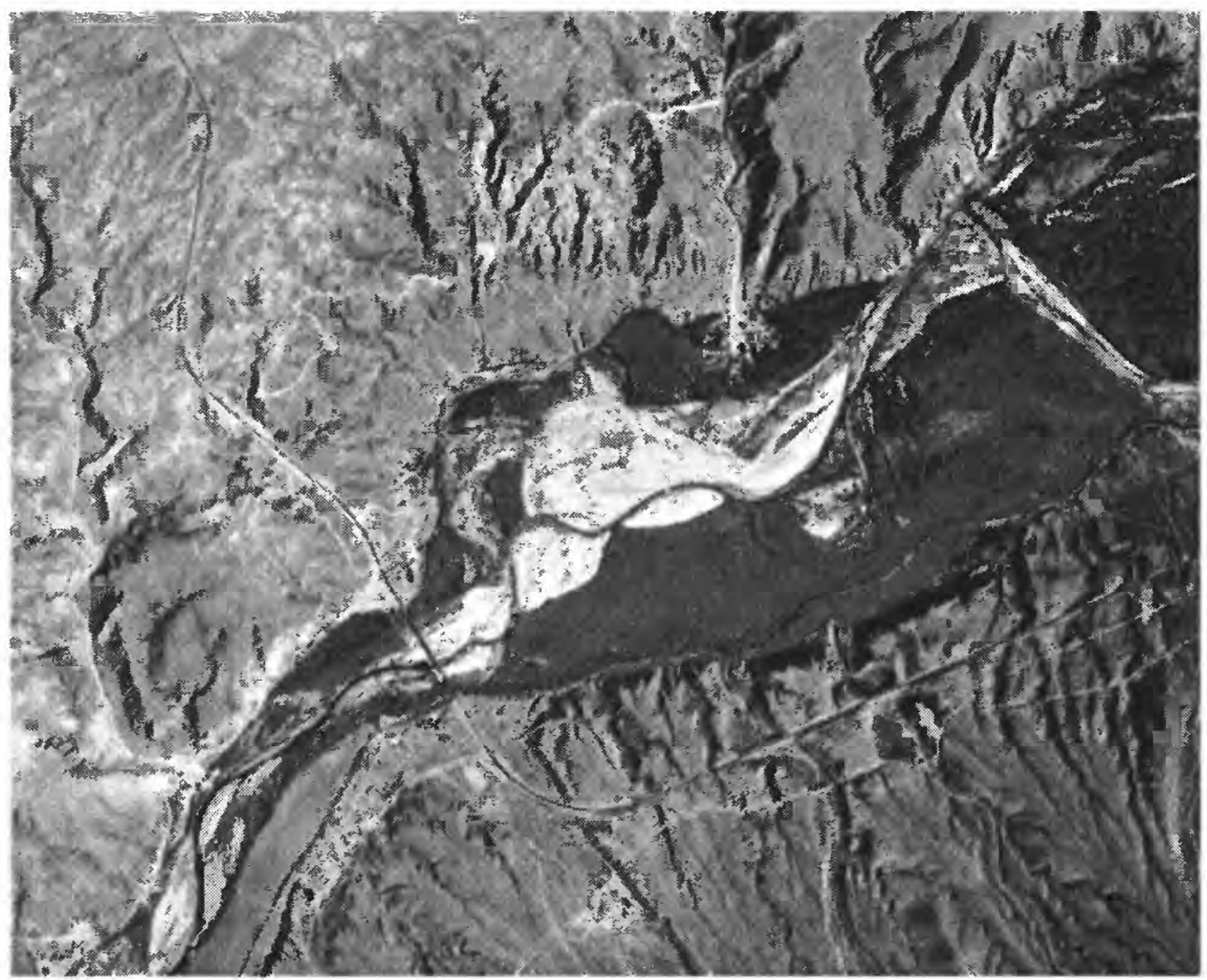

Figure 9. Continued. 
and moved upstream. In 1980, several channel changes were noticeable. The most distinctive was that the channel had straightened, cutting off the large meanders and decreasing the sinuosity once again. The channel also widened in some areas. By 1984, some of the areas that had been cut in 1980 were stabilizing with vegetation, thus decreasing the channel width. In the late 1980 's, a new meander began to form in the area where the old meander was cut off.

In 1994, multiple channels had formed and the channel appeared to have widened recently, as evidenced by a lack of vegetation on the channel margins. This widening was probably the result of high flows in 1993. The large meander upstream from the bridge appeared ready to be cut off by another meander through the center. A smaller meander had formed immediately upstream from the bridge. The 1995 photo (fig. 9D) shows some dramatic changes upstream from the bridge, with another meander being cut off and a major shift of the channel toward the left bank, accompanied by channel widening. Two smaller meanders had formed in place of the larger meander. Downstream from the bridge, just beyond the edge of the photograph (fig. 9D), the channel moved toward the left bank approximately $150 \mathrm{~m}$, leaving the Riverside gaging station abandoned.

The angle of attack on the bridge piers, which can be measured from the aerial photographs (table 7), has changed through time. In the 1938 and 1953 photos, the angle of attack was 45 and 49 degrees southwest, respectively. Between 1973 and 1980, the angle fluctuated back and forth from a northwest angle to a southwest angle. Fluctuation continued in the angle of attack during the 1980's and 1990's, with variations between 0 and 25 degrees to the northwest. This fluctuation is associated with the changing meandering pattern of the river and is indicative of the lateral instability at this site.

\section{Channel Change and Associated Geomorphic Processes}

Several key geomorphic processes have been identified that are important in understanding the changes seen near the bridge sites and for designing bridges to account for future scour. Historical records, including climate, streamflow, and sediment, along with field observations, were used to help relate channel change to specific causes. The geomorphic characteristics and changes for four periods at the bridge sites are summarized in table 8 . These periods were chosen on the basis of channel changes that relate to distinct changes in climate and streamflow. Table 8 can be used to understand the complex relation of the processes and geomorphic changes discussed in this section.

\section{Precipitation and Streamflow}

Most of the channel changes since 1938 correlate well with changes in precipitation and streamflow, although factors such as changes in land use have affected the stability of the river. Four periods showing major changes in precipitation and streamflow were identified by plotting mass curves of the long-term records of precipitation at St. George, Utah, and streamflow at Littlefield, Ariz. (fig. 10). Climate data from St. George, Utah, were used because most runoff in the lower Virgin River drainage basin is from southern Utah. Other precipitation sites within the basin show similar trends. The Littlefield gaging station provides the only long-term streamflow record.

On the basis of figure 10 , the following observations are made. The late 1920's (beginning of data) until the mid 1940's had relatively high precipitation and streamflow. Ground and aerial photographs indicate that the channel was wide and shallow during this period, with sparse vegetation on the flood plain. A second period, mid-1940's to the mid-1970's, is characterized by lower precipitation and streamflow, although the largest natural peak flood $\left(997 \mathrm{~m}^{3} / \mathrm{s}\right)$ occurred during this period. Also, during this period, the channel narrowed considerably, probably due to aggradation and to vegetation becoming established on the channel bars and the flood plain. A third period, the mid-1970's to mid-1980's, is marked by an increase in precipitation and streamflow that resulted in major channel changes, including channel widening and channel avulsion. During a fourth period, the mid-1980's to mid-1990's, precipitation and streamflow decreased again, and the curves have slopes similar to the second period. This decrease resulted in the channel again narrowing as vegetation was able to reestablish along the channel margins that had been widened during the previous wet period. Water years 1993 and 1995 were above average for streamflow, and major channel avulsions also occurred during these 2 years. Some vegetation along the channel margins was removed as a result of the channel widening during the floods. These trends in channel change related to precipitation and streamflow over time are similar to those noted by Hereford (1995, p. 61-62) for the upper Virgin River in Zion Canyon. 


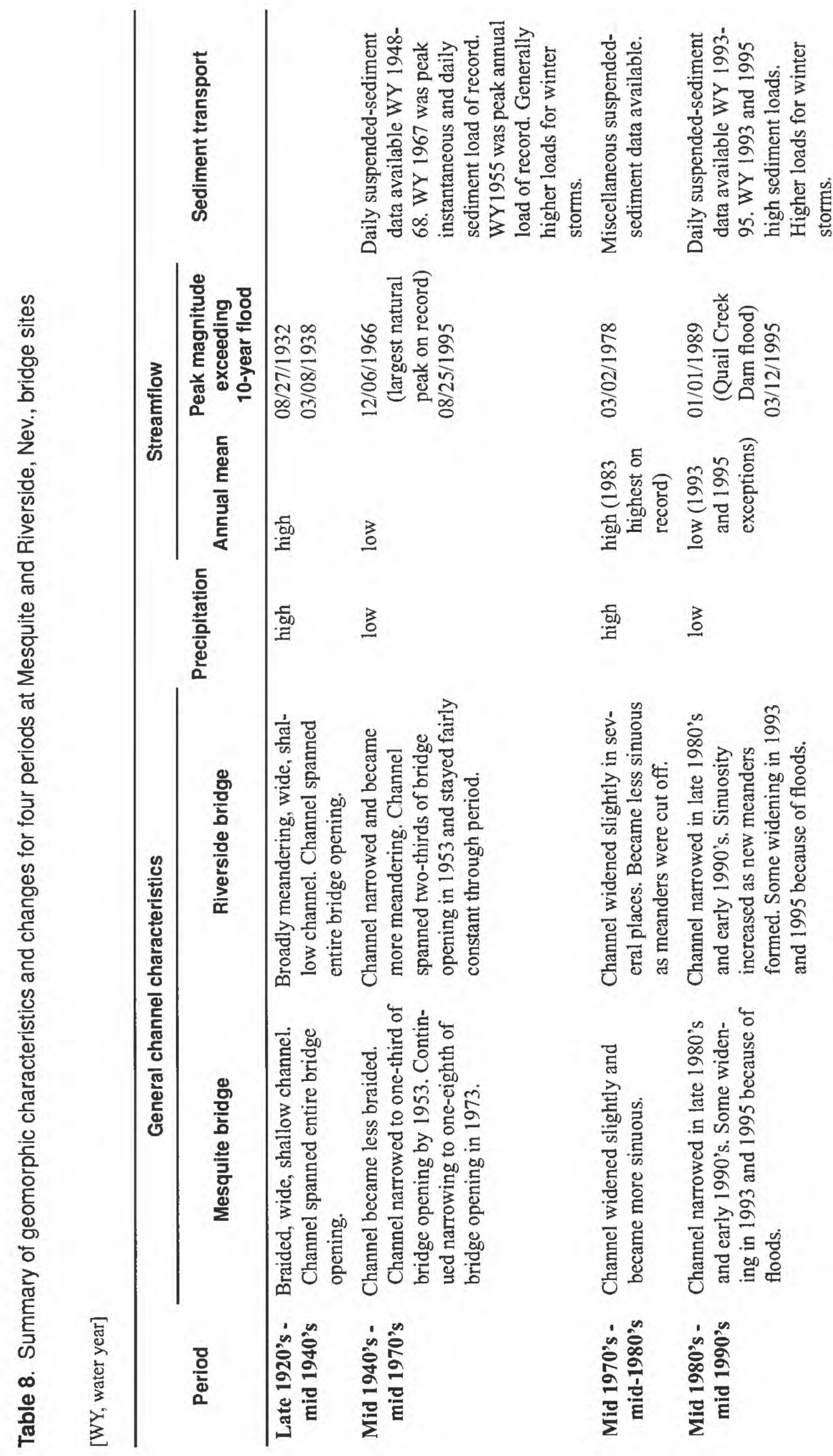




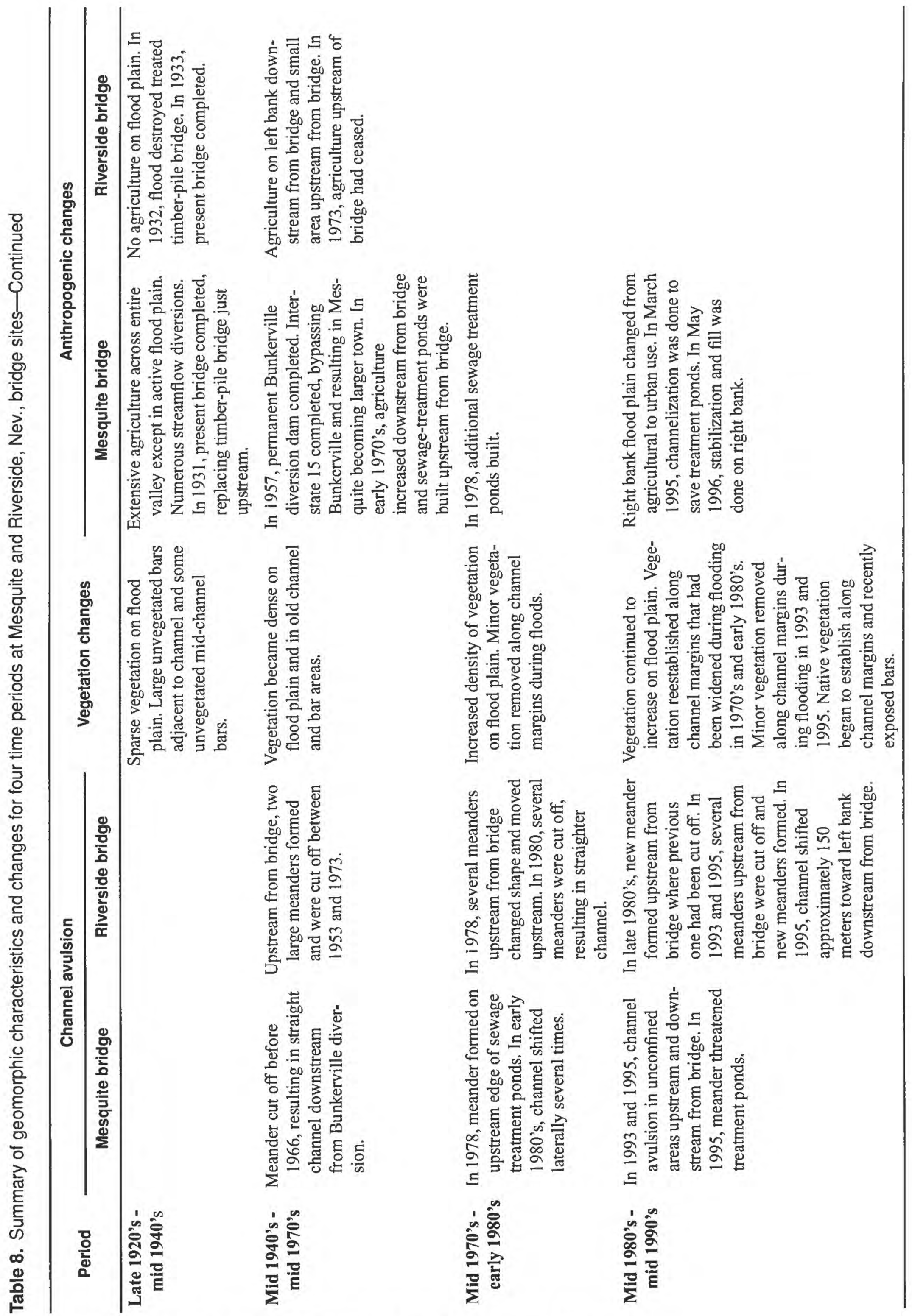



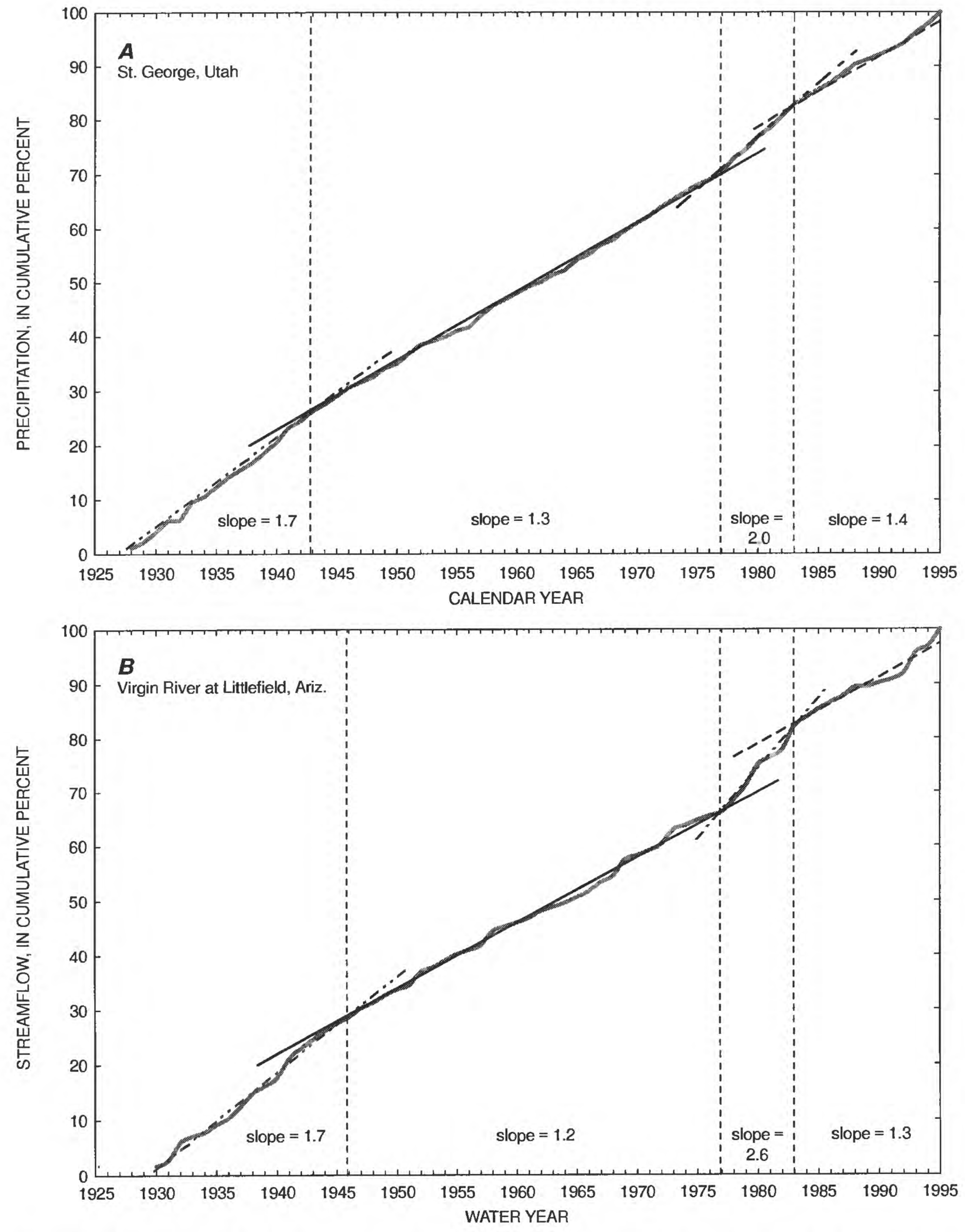

Figure 10. Mass curves of (A) precipitation at St. George, Utah, and (B) streamflow at Virgin River at Littlefield, Ariz. Dashed lines show general trend for period. Calculated slope is based on trend line. 


\section{Flood Magnitude and Flood Duration}

The relation of flood magnitude and duration appears to be an important factor with regard to channel changes of the lower Virgin River. Annual peak discharge and annual mean discharge for the Littlefield gaging station are shown in figure 11 . When data in figure 11 are compared to the aerial photographs, flood magnitude does not relate well to periods of lateral change, but annual mean discharge better relates to periods of lateral change. For example, in 1980, major channel changes were observed near both bridge sites including several meanders being cut off and lateral shifting of the channel. The peak flow for 1980 was $294 \mathrm{~m}^{3} / \mathrm{s}$, approximately a 5-year flood, whereas the annual mean discharge was the second highest on record at $18 \mathrm{~m}^{3} / \mathrm{s}$.

Additional evidence supporting the statement that peak flow is not a good indicator of geomorphic change on the lower Virgin River involves the flood resulting from the failure of Quail Creek Dam. On January 1, 1989, the dam on Quail Creek Reservoir, an off-stream storage reservoir near St. George, Utah, failed, resulting in a peak flow of $1,730 \mathrm{~m}^{3} / \mathrm{s}$ at the Littlefield gaging station. This was nearly twice the discharge of the largest natural flood on record (December 5, 1966). Enzel and others (1994) determined that the magnitude of the flood associated with the Quail Creek Dam failure was similar in magnitude to natural paleofloods on the lower Virgin River during the last 1,000 years. The flood associated with the dam failure was of short duration, remaining near peak stage for 1.5-2 hours (Carlson and Meyer, 1995). The Quail Creek Dam was rebuilt after the 1989 flood.

The erosion and deposition that resulted from the Quail Creek Dam failure are described by Carlson and Meyer (1995). Major channel changes occurred for approximately $80 \mathrm{~km}$ downstream from the dam. For the lower Virgin River, the effects were less evident. Carlson and Meyer (1995) noted that the channel filled $0.03 \mathrm{~m}$ with sand at the Littlefield gaging station and that the flood plain had both aggradation and degradation that decreased downstream. They did not discuss any major lateral shifts in the channel position.

Landsat Thematic Mapper (TM) images taken before and after the Quail Creek Dam failure for the area near the Riverside bridge are shown in figure 12. As previously discussed, this section of the river historically has been one of the most geomorphically dynamic reaches in the lower Virgin River, especially with respect to lateral migration. However, the Landsat images show little evidence of major lateral movement of the channel as a result of this flood. Other areas of the lower Virgin River were examined on the Landsat images and no major lateral shifts of the channel were observed. This short-duration, but extremely high peak flow did not result in major geomorphic change in the study area.

The lack of lateral geomorphic change may be due to the short duration of the flood. This hypothesis is supported by Costa and O'Connor (1995), who found minimal geomorphic changes downstream from two small dam breaks in Oregon and Washington. They attributed the lack of lateral and vertical geomorphic change to the short duration of the flood and not to insufficient stream power ${ }^{l}$ (Nanson and Hean, 1985) or extraordinary stabilization of surfaces by vegetation (Zimmerman and others, 1967). In the lower Virgin River, major channel changes, such as in 1980, have historically resulted from floods that had much lower peak flows and thus lower stream power than that associated with the 1989 flood from the Quail Creek Dam failure. During some of these lower peak discharge floods, new channels have been cut through the vegetation or the channel has been widened resulting in major scour of a vegetated bank. Therefore, lack of lateral geomorphic change as a result of the 1989 Quail Creek Dam failure was not the result of insufficient stream power or stabilization by vegetation.

Duration of the flood is more important than the magnitude of the flood when examining the geomorphic effectiveness on the Virgin River. Longer duration floods of moderate magnitude result in more geomorphic change than short-duration, high-magnitude floods. This is because, for the longer duration floods, the average flood stream power per unit area is high, and total energy expended by the flood is large (Costa and O'Connor, 1995, p. 54). This has the potential to result in tremendous changes to alluvial channels, such as the Virgin River, because stream power remains above the alluvial erosion threshold (Costa and O'Connor, 1995, fig. 11) for a longer time.

\footnotetext{
${ }^{1}$ Stream power is the rate of potential energy expenditure per unit length of channel, or the rate of doing work (Richards, 1982, p. 13).
} 

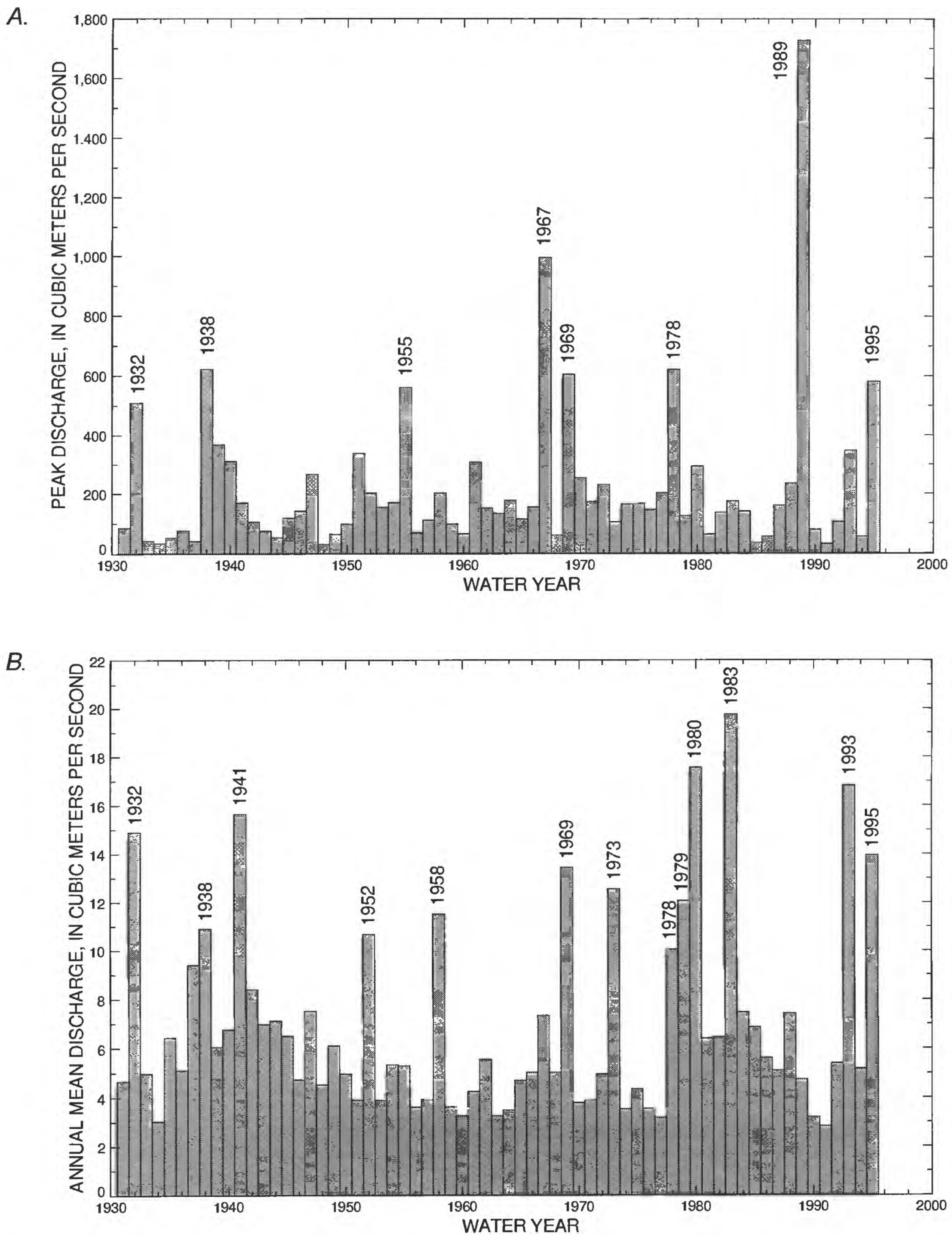

Figure 11. Annual peak discharge (A) and annual mean discharge $(B)$ for Virgin River at Littlefield, Ariz. 
A.
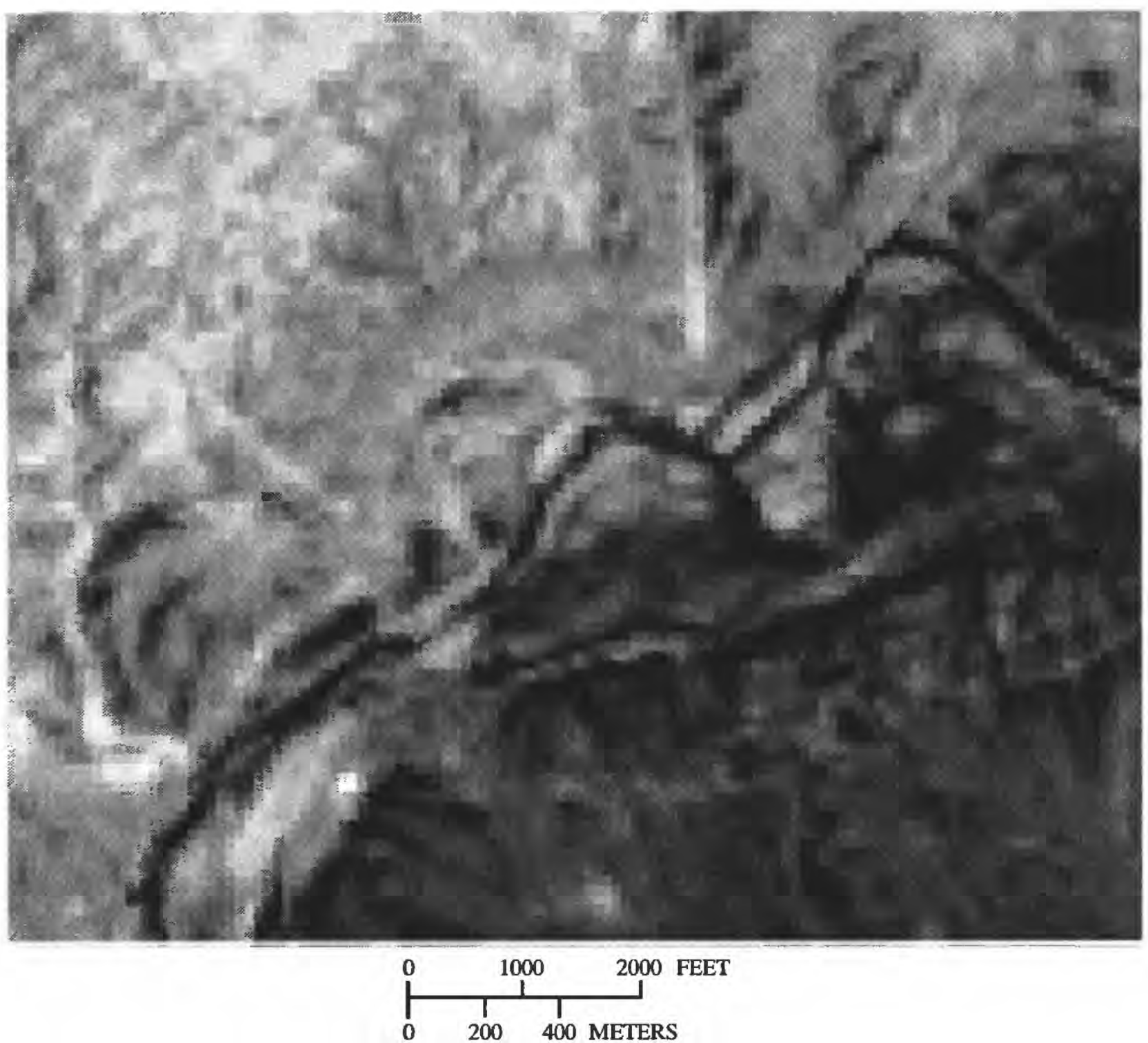

B.

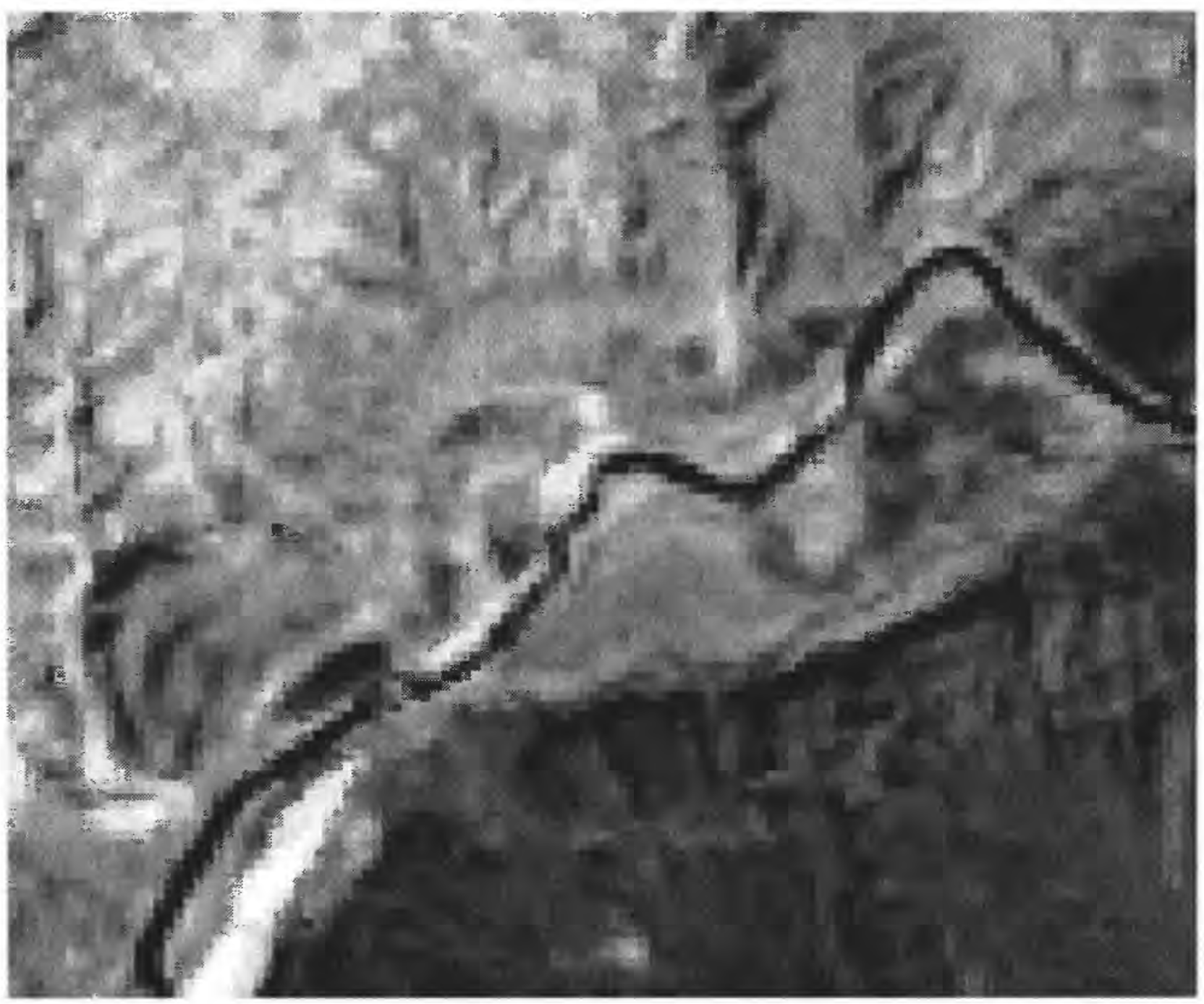

Figure 12. Landsat Thematic Mapper images of Riverside, Nev., bridge area (A) May 10, 1988, before Quail Creek Dam failure, and (B) April 11, 1989, after dam failure. 


\section{Timing of Floods}

The timing of floods also appears to be an important factor when attempting to relate geomorphic processes to channel changes. As previously discussed, the years with high annual mean flow are the years that generally have more geomorphic changes. These years are characterized by multiple floods, generally in the winter, and commonly are followed by high snowmelt runoff in the spring. Water year 1995 was an excellent year to observe how the channel changed during extended periods of high flows and to better understand the geomorphic processes that are acting during such years.

Two small floods (peak flows, $41 \mathrm{~m}^{3} / \mathrm{s}$ and $24 \mathrm{~m}^{3} / \mathrm{s}$, as measured at the Littlefield gaging station) in January 1995 were followed by a larger flood in February $\left(309 \mathrm{~m}^{3} / \mathrm{s}\right)$, and then two larger, closely spaced floods $\left(544 \mathrm{~m}^{3} / \mathrm{s}\right.$ and $\left.581 \mathrm{~m}^{3} / \mathrm{s}\right)$ at the beginning of March. Relatively little channel change was observed during the January and February floods. On the basis of visual observations during and after the floods, some deposition on the flood plain, removal of vegetation, and minor bank collapse occurred near the bridge sites. The banks were saturated and in some places quicksand was a hazard. The first flood in March resulted in increased deposition on the flood plain in some areas and some widening and shifting of the channel upstream from the Riverside bridge. The meander upstream from the Mesquite bridge continued to cut into the right bank near the sewage treatment ponds. The banks were saturated after this flood and quicksand was abundant. However, most of the major changes in the channel happened during the second March 1995 flood.

A series of moderate, longer duration, floodinducing storms, which generally occur in winter, is necessary to cause major channel change. Earlier floods saturate the banks, thus allowing future floods to easily cut a new channel, which in turn results in channel avulsion. A high spring snowmelt runoff, as in March 1995, helps to further establish the channel in its new position. The period of the late 1970's and early 1980 's, when good aerial photographic coverage is available to document channel changes, also shows a large amount of channel avulsion resulting from a series of moderate, longer duration winter floods, specifically in 1978 and 1980.

\section{Sediment-Transport Characteristics}

The suggestion that winter floods generally result in large amounts of geomorphic change is further supported by analyses of seasonal variations of suspendedsediment load of the lower Virgin River (Hilmes, 1996). More than 20 years of sediment data show that the highest instantaneous and daily sediment loads generally occur during winter floods, although summer and fall floods often produce the highest instantaneous and daily sediment concentrations. The loads are higher for the winter floods because the winter floods are generally of longer duration and have a higher water discharge than the summer floods. Therefore, sediment transport is generally higher for the winter floods than the summer floods, and it directly affects channel morphology by aggradation, degradation, or lateral shifting.

Hilmes (1996) also compared loads from water year 1993 to the historical record of water years 194868 and found that the Quail Creek Dam failure did not deplete or increase the amount of sediment available for transport in the lower Virgin River. Annual suspended-sediment loads before and after the Quail Creek Dam failure were commonly greater than 4 million metric tons at the Littlefield gaging station. The highest annual suspended-sediment load on record was $6,360,000$ metric tons in 1955 . These data also suggest that the construction of Quail Creek Reservoir in 1985 did not result in decreased sediment loads. Because Quail Creek Reservoir is an off-stream impoundment and does not interfere with the high sediment loads carried by floods on the Virgin River, it was not unusual to find no change in the sediment loads of the mainstem river.

\section{Channel Avulsion}

On the lower Virgin River, channel avulsion appears to be a much more important process than the slower, more gradual channel migration process seen on many rivers. Migration of meander bends does occur, and is more noticeable during the lower streamflow years because it is often overshadowed during high streamflow years by the much more noticeable process of channel avulsion. One important process relating to channel avulsion is the plugging of the channel with sediment, or aggradation. The channel becomes plugged with sediment and the river then cuts through the saturated bank, forming a new channel and thereby abandoning the former channel (which is 
usually a meander bend). Channel-geometry surveys between 1994 and 1995 show up to $2 \mathrm{~m}$ of aggradation in some of the recently abandoned channels. Sediment loads in the Virgin River, like in many southwestern United States streams, can be high. The highest instantaneous suspended-sediment load for the March 1995 flood measured at the Riverside bridge was $1,430,000$ metric tons per day, with an associated suspendedsediment concentration of $40,300 \mathrm{mg} / \mathrm{L}$ and a water discharge of $411 \mathrm{~m}^{3} / \mathrm{s}$ (Bauer and others, 1996, p. 65). Bedload was not measured because of the high streamflow velocities. However, visual analysis of the sediment deposited from the March 1995 flood showed that large cobble-size material (median diameter, $46 \mathrm{~mm}$ ) was transported as bedload. These high sediment loads result in the plugging of the channel with sediment, which leads to channel avulsion.

\section{Vegetation}

Vegetation changes on the flood plain of the lower Virgin River have affected channel stability. Today, the flood plain is covered almost entirely by tamarisk (saltcedar). Tamarisk is a non-native species, indigenous to the Mediterranean area, that was introduced in the United States first as an ornamental plant and then later as an erosion-control plant (Robinson, 1958). Tamarisk was thought to have been introduced into many southwestern United States streams in the late 1800's to early 1900's when tamarisk "escaped from cultivation" (Robinson, 1965, p. A1). However, Escalante reportedly identified tamarisk in 1776 in Fort Pierce Wash, a tributary to the Virgin River, near the Utah-Arizona border (Christensen, 1962, p. 53).

On the basis of historical research of many southwestern streams, Christensen (1962) found that tamarisk spread rapidly from approximately 1925 to 1960 , with the greatest invasion from approximately 1935 to 1955. This increase corresponds with the observed changes in vegetation density seen in the historical aerial photography for the lower Virgin River. In the 1938 photos (figs. $8 A$ and $9 A$ ), vegetation is sparse on the flood plain, but by 1953 (figs. $8 B$ and $9 B$ ) the vegetation density has greatly increased. Although the type of vegetation cannot be positively determined from the aerial photography, tamarisk presumably dominates.

By 1953, the vegetation occupied areas that had been part of the old channel and this coincides with the period when channel narrowing was observed. Thus, the vegetation encroachment and channelnarrowing process were related and probably occurred simultaneously as a result of decreased discharges during the mid-1940's to mid-1970's. Aggradation of the flood plain also probably occurred when the river overflowed the banks. These geomorphic processes are consistent with those observed on many southwestern streams (Graf, 1978, 1987; Hereford, 19?1, 1986, 1995).

Tamarisk has continued to play an important role in the more recent channel stability of th $>$ river. The density of vegetation on the flood plain continues to increase, although it is often destroyed in localized areas along the channel margins during $\mathrm{r}$ igher streamflow, such as in the late 1970's-early 1980's. The only time that large amounts of flood-plain vegetation are destroyed is when channel avulsion occurs. However, tamarisk quickly recolonizes exposed bars and begins to stabilize them, resulting in continued channel narrowing and deepening. Recently, more native plants, such as willows, have begun revegetating some of the newly exposed bars and margins of the channel where widening was localized during the wet years of 1993 and 1995 . The native vegetation may cortinue to dominate these areas or the tamarisk may eventually outcompete the native vegetation, as in the past. Regardless of the type of vegetation now occupying the channel margins, the channel is likely to remain narrow and meandering unless a long-term increase in streamflow results in the removal of the vegetation on the flood plain.

\section{Anthropogenic Influences}

Anthropogenic influences are important for understanding many of the observed channel changes, especially at the Mesquite bridge site. The Virgin River Valley was first colonized in 1864 at a site approximately $1.6 \mathrm{~km}$ upstream from Littlefield, Ariz., near the mouth of Beaver Dam Wash. The largest early settlement was Bunkerville, Nev., established in 1877. Bunkerville was a Mormon agricultural community that grew cotton, grain, and fruit. The town of Mesquite was first established in 1879 , but was abandoned in 1891 due to a flood (Hulse, 1972) and then reestablished in 1895. Bunkerville, just across the river from Mesquite, continued to be the larger towr until the segment of Interstate 15 west of Mesquite was completed, bypassing Bunkerville. In the past several years, Mesquite has been growing rapidly as a major tourist center; the increased urban develosment has resulted in many changes to the flood plain of the Virgin River, and thus to the channel stability. 
The first anthropogenic change to the flood plain was from agriculture. To irrigate the agricultural area, several irrigation diversions were built along the river and many are still in operation, having been rebuilt after almost every major flood. These diversions generally control the position of the river at least to some degree, but during periods of high streamflow the river often destroys these structures and cuts a new channel. Through time, many owners of these agricultural areas have tried to use some form of bank stabilization (old cars and tires, for example) in an attempt to keep the Virgin River from eroding the land. Stabilization efforts were often unsuccessful, especially during larger floods. During periods of low to moderate streamflow, the bank stabilization has constricted the channel and not allowed the river to utilize the entire flood plain as it had historically, resulting in a narrow, deep channel with confined meanders and steep channel gradients.

In addition to agriculture encroaching on the flood plain, more recent urban developments, such as the sewage-treatment ponds, have further confined the valley width and the area in which the channel is able to migrate. This confinement appears to be a major factor associated with the scour problem at the Mesquite bridge. The channel reach that includes the bridge is naturally constricted compared to channel reaches upstream and downstream. The natural constriction is further enhanced by the encroaching agriculture and sewage-treatment ponds. By forcing the river to go through a narrower opening, the river must find a way to dissipate its energy. The two most obvious ways for the river to dissipate its energy are to meander, reducing the channel gradient, or to downcut, resulting in scour. Beginning about 1978 , according to the aerial photographs, the river began forming a meander that threatened the sewage treatment ponds. This meander has been physically removed several times by channelization, but continues to reform as the river minimizes its energy in the constricted zone. By limiting lateral migration and further confining the channel by continued development on the flood plain, the expected result will be an increase in scour, causing increased problems for the structural stability of the Mesquite bridge.

A similar response has been observed at the Riverside bridge, although this study reach has not been as greatly influenced by anthropogenic changes. Agricultural areas have encroached on the flood plain immediately downstream from the bridge. The natural valley constriction at the Riverside bridge is prominent. The response of the river has been to form large mean- ders upstream from the bridge. The meandering process has not been altered and is thought to be a main reason for the reduced scour problem at this bridge as compared with scour at the Mesquite bridge.

\section{SUMMARY AND CONCLUSIC VS}

A bridge-scour study by the U.S. Geological Survey, in cooperation with the Neva Ja Department of Transportation, began in April 1996 to evaluate the Mesquite, Nev., and Riverside, Nev., bridges on the lower Virgin River using a sediment-transport model and historical geomorphic data. The BRIdge Stream Tube model for Alluvial River Simulation (BRI-STARS) was used to estimate bridge scour. The model was first calibrated using information from a flood on March 12, 1995. Model-input data included channel geometry, bed-material size distributions, streamflow-hydrograph data, water-scrface altitudes at the initial downstream cross section, a water-temperature value, roughness coefficients, and a sedimenttransport equation. Channel geometry was surveyed at 11 cross sections for dates before and after the March 1995 flood to evaluate the model results. The model estimated the thalweg altitude within $\pm 1 \mathrm{~m}$ at 10 of the 11 cross sections. On the basis of the calibration results compared to the observed channel changes between 1994 and 1995, the model provides a good estimate of scour at the bridges.

The calibrated model then was used to estimate the contraction, channel, pier, and total scour or fill for synthesized hydrographs of the 100- and 500-year floods for the two bridge sites. The maximum contraction and channel scour or fill at the Mesquite bridge was $0.20 \mathrm{~m}$ of fill for the 100 -year flood and $0.22 \mathrm{~m}$ of fill for the 500-year flood and at the Riverside bridge was $0.41 \mathrm{~m}$ of scour for the 100 -year flood and $0.47 \mathrm{~m}$ of scour for the 500-year flood. The maximum pier scour at the Mesquite bridge was $1.5 \mathrm{C} \mathrm{m}$ of scour for the 100-year flood and $1.54 \mathrm{~m}$ of scour for the 500 -year flood and at the Riverside bridge was $1.49 \mathrm{~m}$ of scour for the 100-year flood and $1.54 \mathrm{~m}$ of scour for the 500 year flood. The maximum total scour at the Mesquite bridge was $1.30 \mathrm{~m}$ for the 100 -year flood and $1.32 \mathrm{~m}$ for the 500-year flood and at the Rive"side bridge was $1.90 \mathrm{~m}$ for the 100 -year flood and $2.01 \mathrm{~m}$ for the 500 year flood. The simulated scour for the $100-$ and 500 year floods was less than anticipated at the bridges on the basis of the scour computed for the lower magnitude floods used in the calibration process. The cross sections also showed little scour for the 100- and 
500 -year floods. The low scour may be attributed to the large amount of sediment being transported and how the model was designed.

General scour was evaluated using stagedischarge relations, 1993-95 channel cross sections, and channel-geometry data for the modeled 100- and 500 -year floods. No long-term trend of aggradation or degradation was determined from analysis of stage and discharge at the Littlefield gaging station. However, several cycles of aggradation and degradation were observed and the difference between the highest and lowest stage was $0.87 \mathrm{~m}$ for $1929-95$ for a chosen lowflow discharge of $5.66 \mathrm{~m}^{3} / \mathrm{s}$. This value is probably the best estimate of general scour. The cross sections had an average depth of scour of $0.07 \mathrm{~m}$ between 1993 and 1994 and $0.16 \mathrm{~m}$ between 1994 and 1995. The model results for the 100- and 500-year floods showed little scour at the cross sections and did not give a good estimate of general scour, probably because the duration (days) of the floods used in the model was relatively short compared with the duration (months or years) of geomorphic processes that influence long-term aggradation or degradation.

Channel morphology of the Virgin River near the Mesquite and Riverside bridges has changed dramatically, as evident from the historical aerial photography. The Virgin River has become narrower and more sinuous through time, the vegetation on the flood plain has increased, and the channel has shifted laterally many times. To understand why the river has changed through time and how this relates to the current bridgescour problem, all the geomorphic processes and factors need to be considered.

Climate and streamflow records indicate that the early 1990's was a relatively dry period, with 1993 and 1995 being abnormally high streamflow years. Historically, the greatest channel changes have occurred during longer duration floods that were generally part of a series of floods in which the first few do not result in much geomorphic change, but subsequent ones result in greater channel change, probably due to saturated channel bank conditions. Channel avulsion, a result of sediment plugging the old channel, appears to be the process that results in the most noticeable channel changes. Sediment loads are higher for winter floods because winter floods are generally of longer duration and have a greater water discharge than the summer floods. Construction of Quail Creek Reservoir near St.
George, Utah, did not result in decreased sediment loads in the Virgin River because the reservoir is offstream. When Quail Creek Dam failed on January 1, 1989, the resulting flood did not cause much geomorphic change to the lower Virgin River, probably because of its short duration. Vegetation and anthropogenic influences, especially those related to flood-plain encroachment, have played important ro'es in channel stability and are probably key factors in the vertical scour at the bridge sites.

If any of these geomorphic factors change in the future, accompanying changes are likely in the stability of the river. Some of these factors, such as long-term trends in streamflow as a result of climate change and the channel avulsion process, cannot be easily managed. However, anthropogenic influences such as encroachment on the flood plain and regulation of flow, can be controlled. The geomorphic processes acting on the Virgin River are among the factors to be considered when designing bridges and other structures.

\section{REFERENCES CITED}

Bauer, D.J., Foster, B.J., Joyner, J.D., and Swanson, R.A., 1996, Water resources data, Nevada, water year 1995: U.S. Geological Survey Water-Data Rerort NV-95-1, $734 \mathrm{p}$.

Cardinalli, J.L., Roach, L.M., Rush, F.E., and Vasey, B.J., 1968, State of Nevada hydrographic areas: Nevada Division of Water Resources map, scale 1:500,000.

Carlson, D.D., and Meyer, D.F., 1995, Flood on the Virgin River, January 1989, in Utah, Arizona, and Nevada: U.S. Geological Survey Water-Resources Investigations Report 94-4159, 21 p.

Chang, H.H., 1988, Fluvial processes in river engineering: Malabar, Fla., Krieger Publishing Compэny, 432 p.

Christensen, E.M., 1962, The rate of naturalization of Tamarix in Utah: The American Midland $\mathrm{Na}^{+}{ }^{+} \mathrm{Iralist}, \mathrm{v}$. 68 , no. 1, p. 51-57.

Clary, S.L., McClary, D.R., Whitney, Rita, and Reeves, D.D., 1995, Water resources data, Nevada, water year 1994: U.S. Geological Survey Water-Da+a Report NV-94-1, $768 \mathrm{p}$.

Costa, J.E., and O'Connor, J.E., 1995, Geomorphically effective floods, in Costa, J.E., Miller, A.J., Potter, K.W., and Wilcock, P.R., eds., Natural and anthropogenic influences in fluvial geomorphology: American Geophysical Union, Geophysical Monograph 89, p. 45-56. 
Enzel, Yehouda, Ely, L.L., Martinez-Goytre, Juan, and Vivian, R.G., 1994, Paleofloods and a dam-failure flood on the Virgin River, Utah and Arizona: Journal of Hydrology, v. 153, p. 291-315.

Eychaner, J.H., 1976, Estimating runoff volumes and flood hydrographs in the Colorado River basin, southern Utah: U.S. Geological Survey Water-Resources Investigations Report 76-102, $18 \mathrm{p}$.

Fan, Shou-shan, ed., 1988, Twelve selected computer stream sedimentation models developed in the United States: Federal Energy Regulatory Commission, Interagency Advisory Committee on Water Data.

Fletcher, F.N., 1980, Early Nevada-The period of exploration 1776-1848: Reno, University of Nevada Press, $183 \mathrm{p}$.

Graf. W.L., 1978, Fluvial adjustments to the spread of tamarisk in the Colorado Plateau region: Geological Society of America Bulletin, v. 89, p. 1491-1501.

-1987, Late Holocene sediment storage in canyons of the Colorado Plateau: Geological Society of America Bulletin, v. 99, p. 261-271.

Hafen. L.R., and Hafen, A.W., eds., 1959, The diaries of William Henry Jackson, frontier photographer- to California and return, 1866-67; and with the Hayden Surveys to the central Rockies, 1873, and to the Utes and cliff dwellings, 1874: Glendale, Calif., A.H. Clark Co., The Far West and the Rockies Historical Series, 1820-1875, v. $10,345 \mathrm{p}$.

Hereford, Richard, 1984, Climate and ephemeral-stream processes - Twentieth-century geomorphology and alluvial stratigraphy of the Little Colorado River, Arizona: Geological Society of America Bulletin, v. 95, p. 654-668.

1986, Modern alluvial history of the Paria River basin, southern Utah: Quaternary Research, v. 25. p. 293-311.

1995. Geomorphic history of the Virgin River in the Zion National Park area, southwest Utah: U.S. Geological Survey Open-File Report 95-515, 75 p.

Hilmes, M.M., 1996, Seasonal variation of suspended-sediment transport in the lower Virgin River, Arizona and Nevada: Sixth Federal Interagency Sedimentation Conference, Subcommittee on Sedimentation, Interagency Advisory Committee on Water Data, Las Vegas, March 1996, Proceedings, v. 2, p. poster 6 - poster 11.

Hulse, J.W., 1972, The Nevada adventure-A history: Reno, University of Nevada Press, $324 \mathrm{p}$.

Interagency Advisory Committee on Water Data, 1982, Guidelines for determining flood flow frequency: Washington, D.C., Interagency Advisory Committee on Water Data, Hydrology Subcommittee Bulletin 17B, $183 \mathrm{p}$.

Larson, A.K., 1961, I was called to Dixie: Salt Lake City, Utah, Deseret News Press, 681 p.
Molinas, Albert, 1990, User's Manual for BRI-STARSBRIdge Stream Tube model for Alluvial River Simulation: Fort Collins, Colo., Hydrau-Tech, Inc., National Cooperative Highway Research Program Project Report, $80 \mathrm{p}$.

Nanson, G.C., and Hean, D., 1985, The West Dapto flood of February 1984 Rainfall characteri changes: Australian Geography, v. 16, no. 4, p. 249258.

National Climatic Data Center, 1992, Monthly station normals of temperature, precipitation, and heating and cooling degree days, 1961-90: 1 Tational Oceanic and Atmospheric Administration, C"imatography of the United States no. 81, $21 \mathrm{p}$.

Richards, Keith, 1982. Rivers, form and process in alluvial channels: New York, Methuen and Company, $361 \mathrm{p}$.

Richardson, E.V., and Davis, S.R., 1995, Evaluating scour at bridges: Federal Highway Administ"ation Hydraulic Engineering Circular 18, Publication FHWA-IP-90$017,203 \mathrm{p}$.

Robinson, T.W., 1958, Phreatophytes: U.S. Geological Survey Water-Supply Paper 1423, $84 \mathrm{p}$.

1965, Introduction, spread, and areal extent of saltcedar (Tamarix) in the western states: U.S. Geological Survey Professional Paper 491-A, 12 p.

Rush, F.E., 1968, Index of hydrographic areas in Nevada: Nevada Division of Water Resource? Information Report 6, $38 \mathrm{p}$.

Shearman, J.O., 1990, User's manual for WSPRO--A computer model for water-surface profile computations: Federal Highway Administration Publication FHWAIP-89-027, $177 \mathrm{p}$.

Vaill, J.E., 1995, Application of a sedime.t transport model to estimate bridge scour at selected sites in Colorado, 1991-93: U.S. Geological Survey Water-Resources Investigations Report 95-4179, $37 \mathrm{p}$.

Waltemeyer, S.D., 1995, Bridge-scour analysis on Cuchillo Creek at the Interstate 25 crossing near Truth or Consequences, New Mexico: U.S. Geological Survey WaterResources Investigations Report 95-4050, 29 p.

Wheeler, G.M., and Lockwood, D.W., 1875, Preliminary report upon a reconnaissance through southern and southeastern Nevada [Geographical Surveys West of the 100th Meridian]: Washington, D.C., Government Printing Office, $72 \mathrm{p}$.

Wolman, M.G., 1954, A method of sampling coarse riverbed material: American Geophysical Union Transactions, v. 35, no. 6, p. 951-956.

Zimmerman, R.C., Goodlett, J.C., and Comer, G.H., 1967, The influence of vegetation on chanrel form in small streams: International Association of Hydrologic Science Publication, v. 75, p. 225-275. 


\section{APPENDIX A}

1995 Surveyed Cross Sections in Relation to Resulting Model Cross Sections 


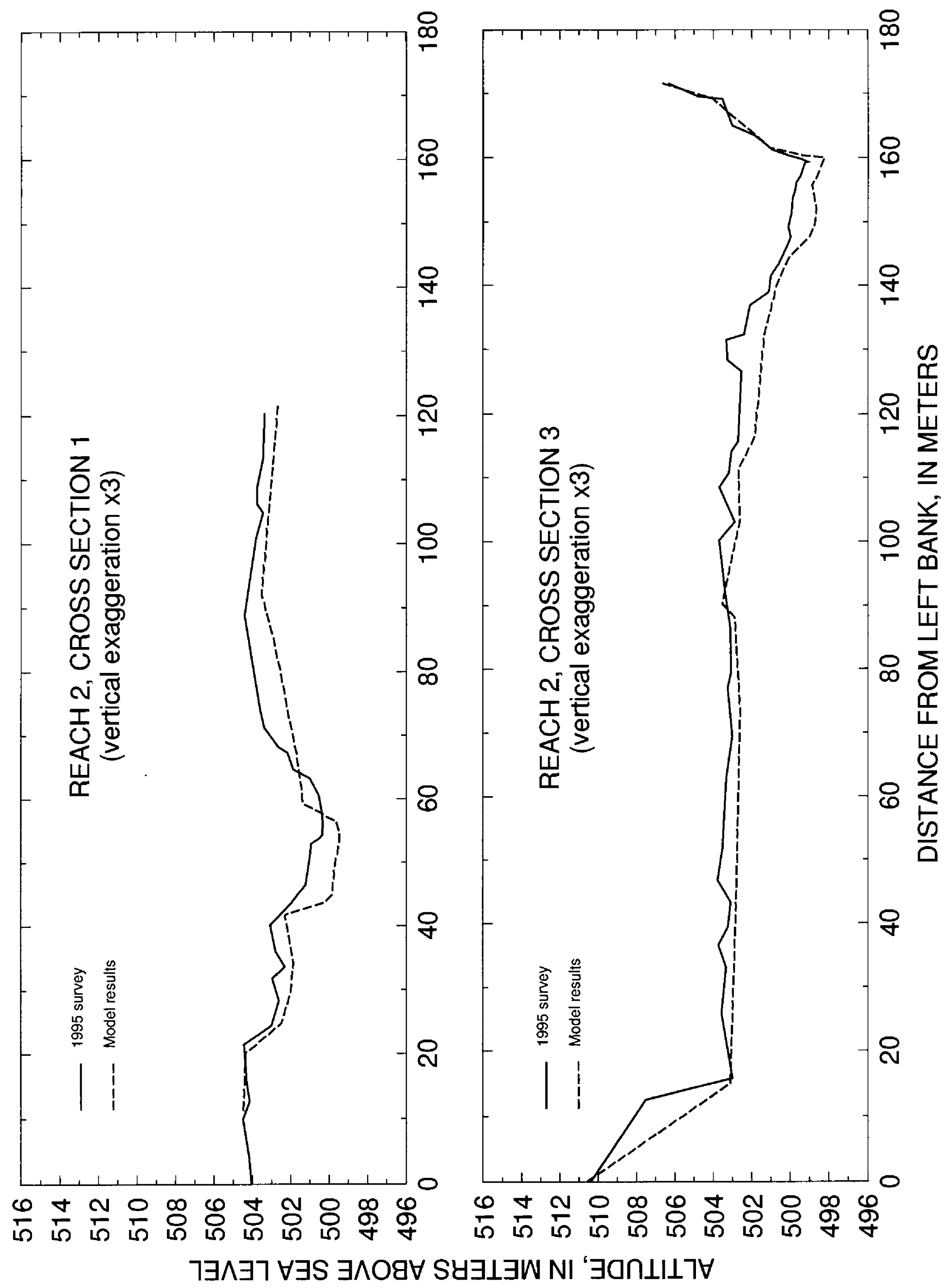




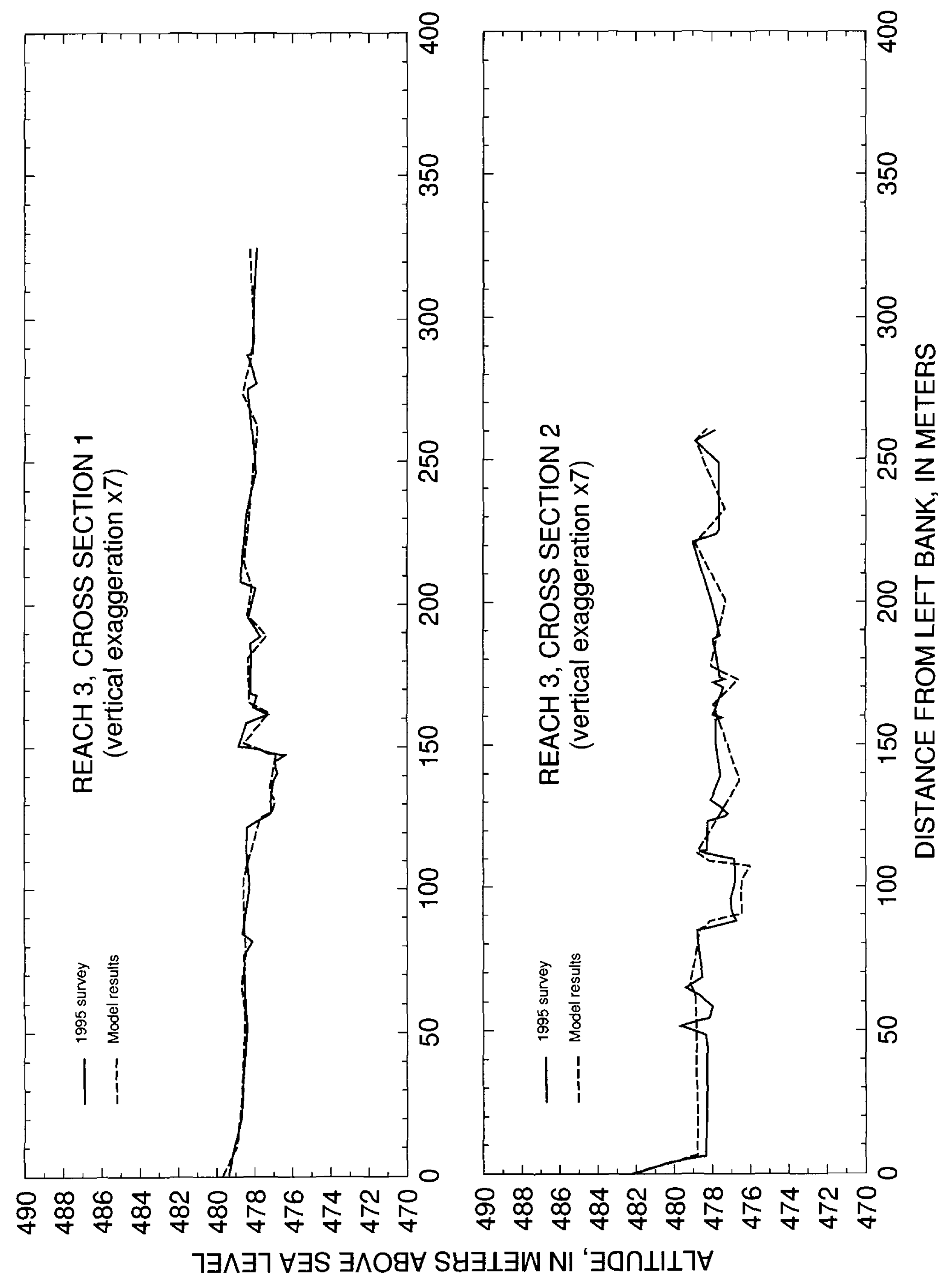




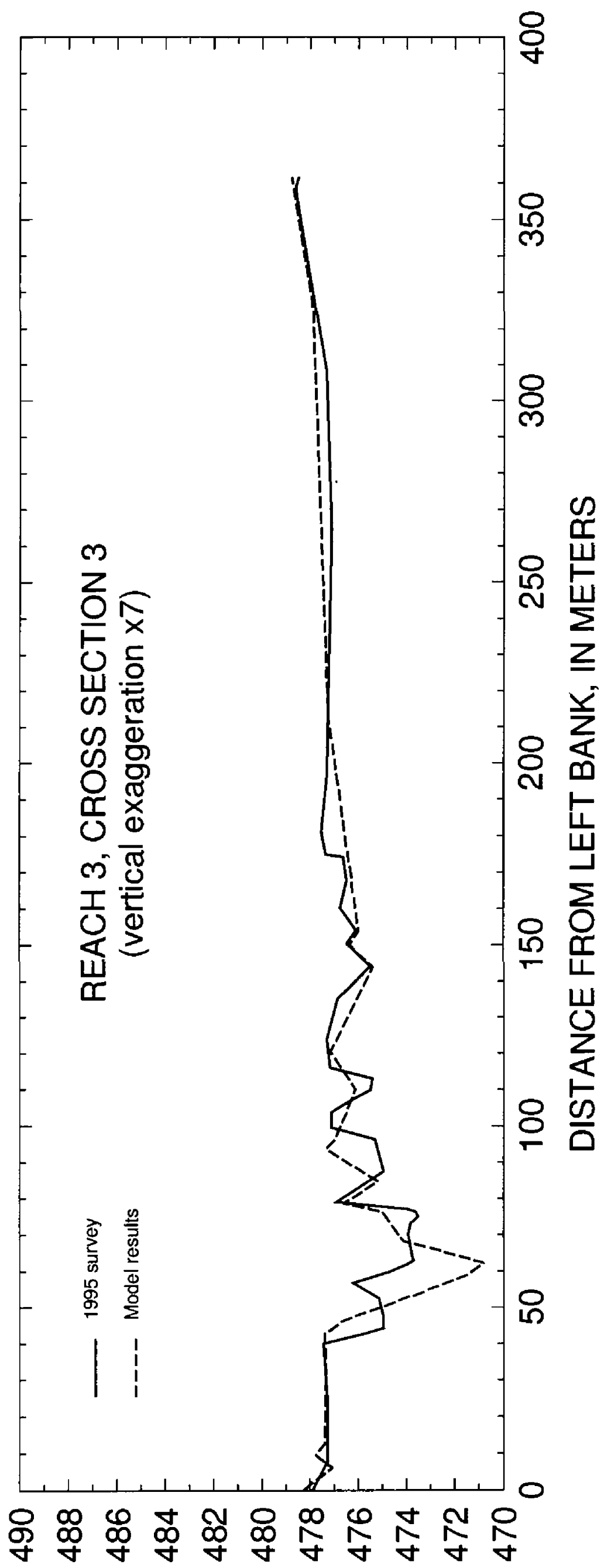

า $\exists \wedge \exists า \forall \exists S ~ \exists \wedge O 8 \forall$ S $\forall \exists \perp \exists W$ NI ' $\exists O \cap \perp I\urcorner \forall$ 


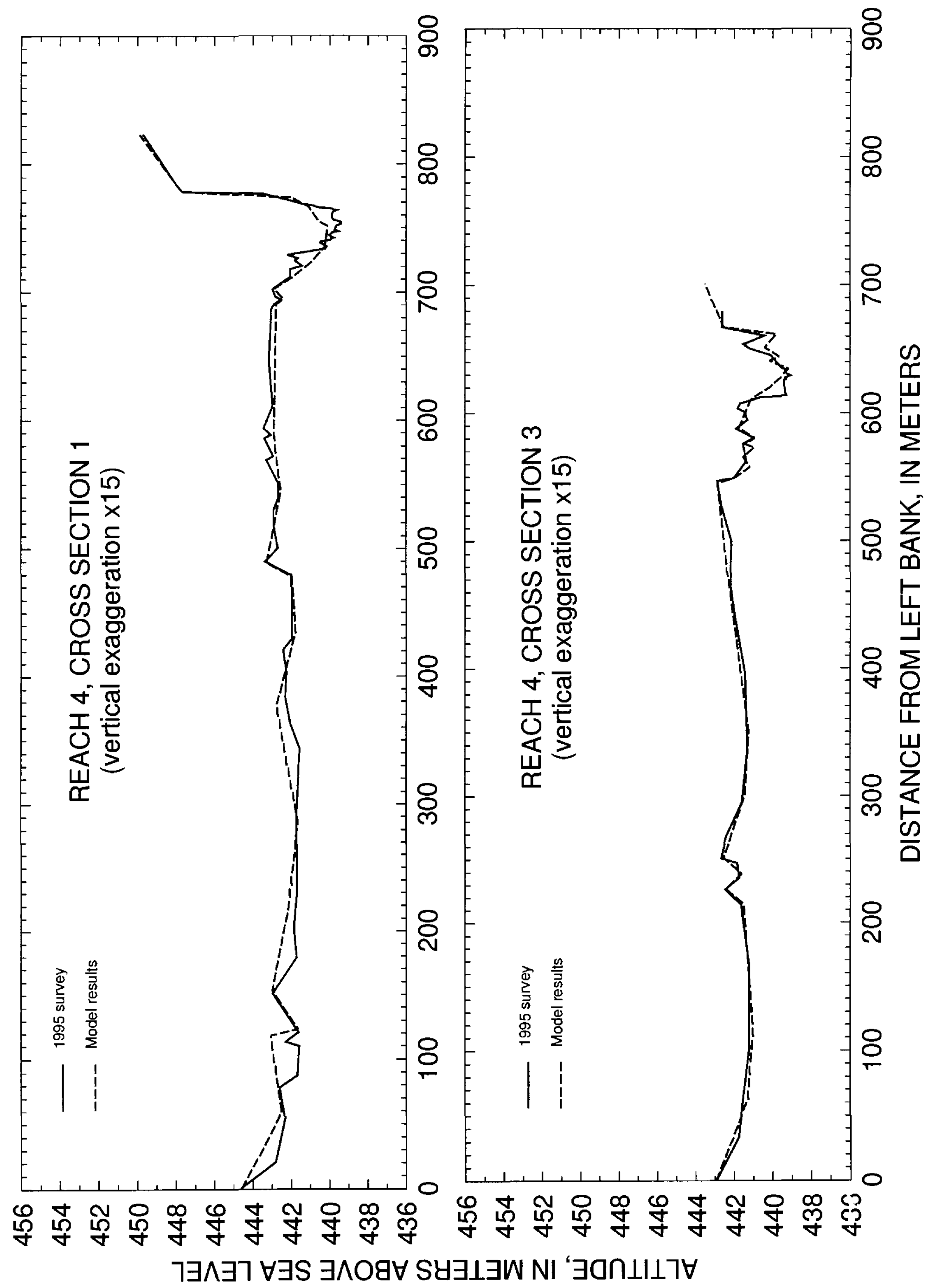




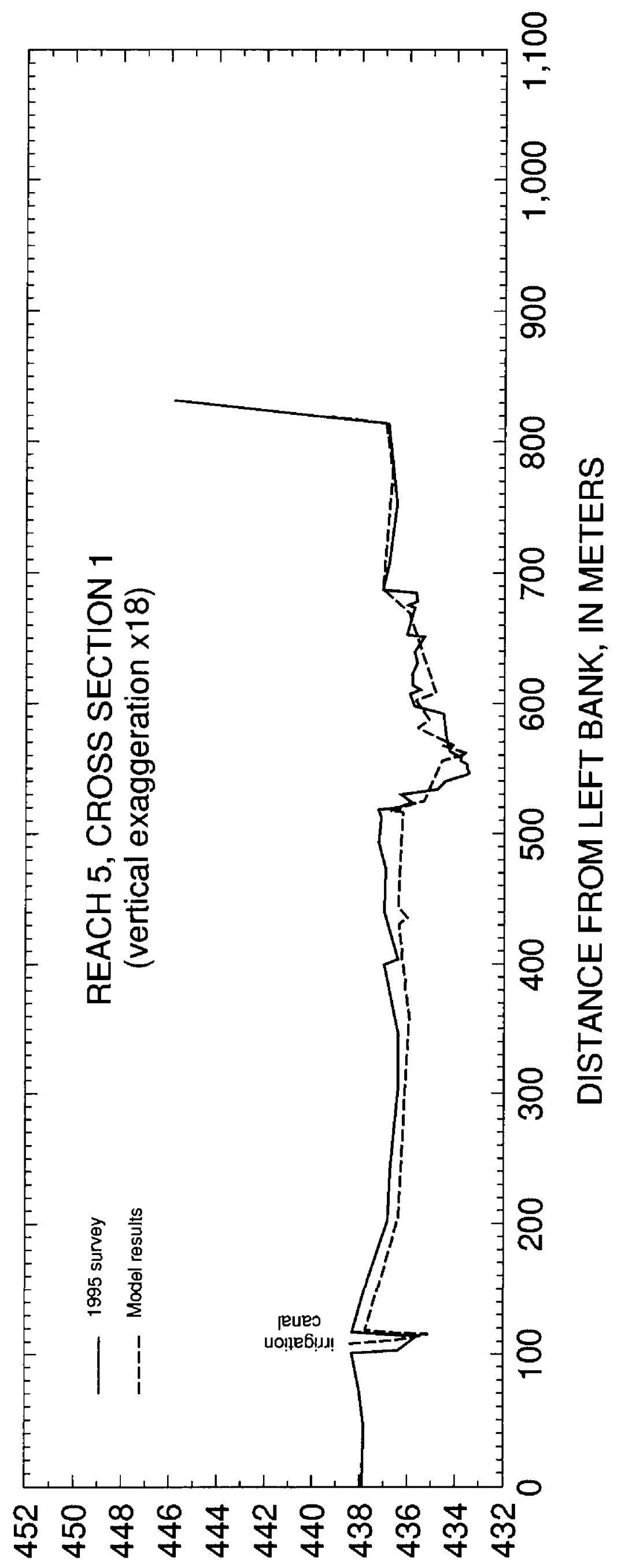

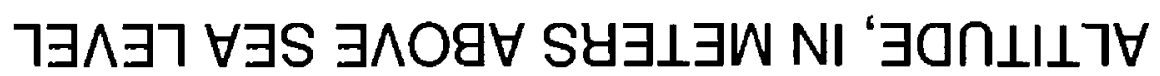




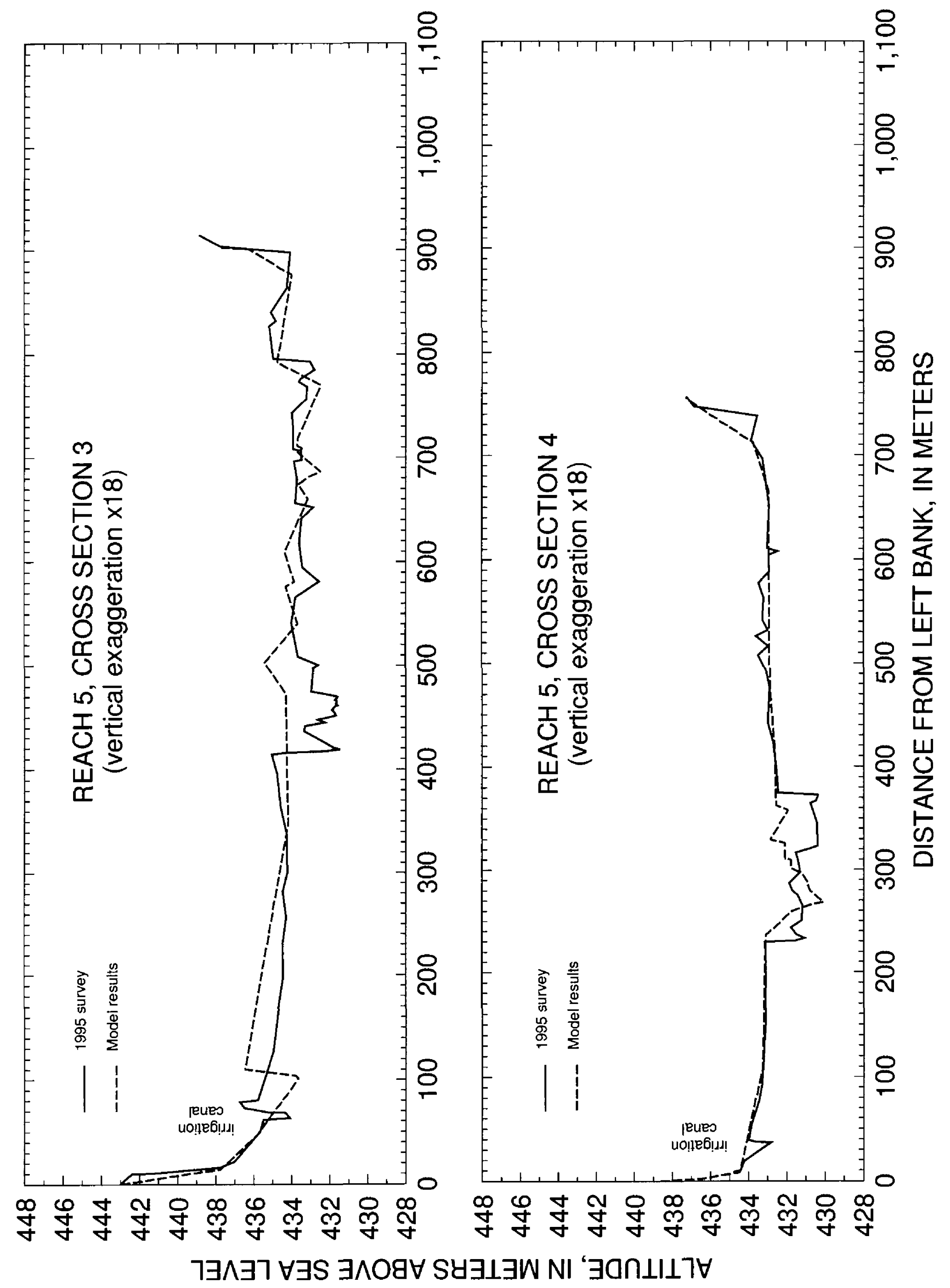




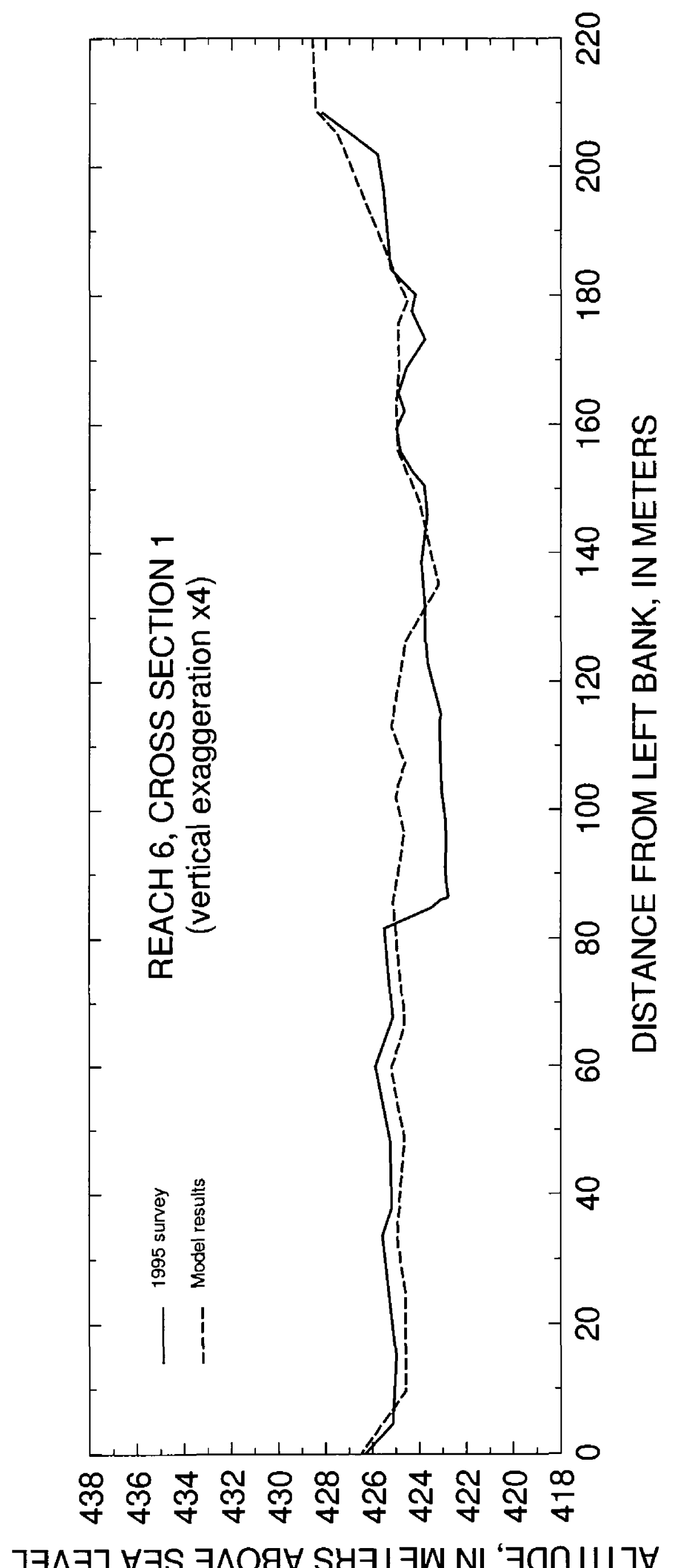




\section{APPENDIX B}

Channel Geometry of Cross Sections Surveyed in 1993, 1994, and 1995 


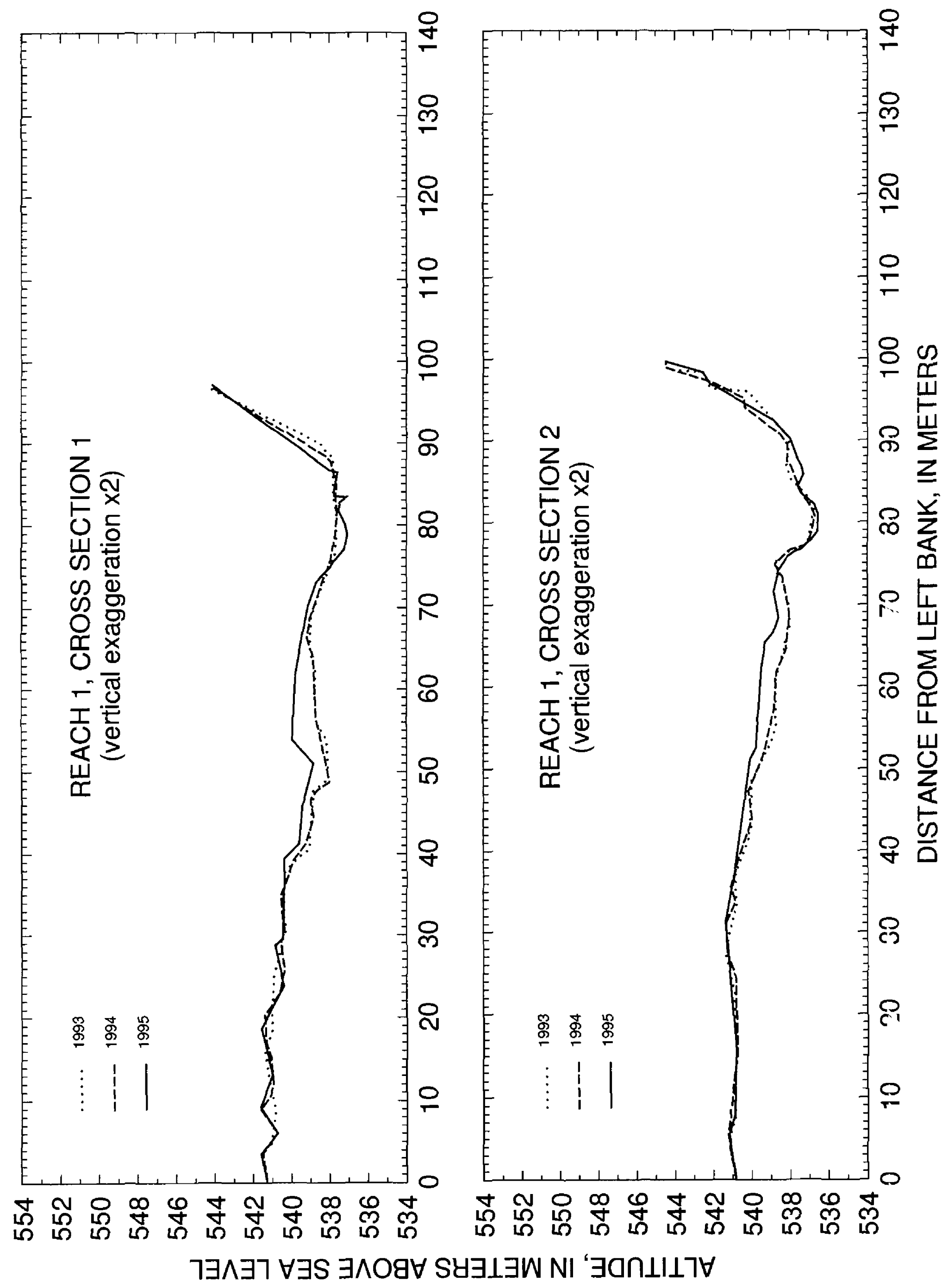




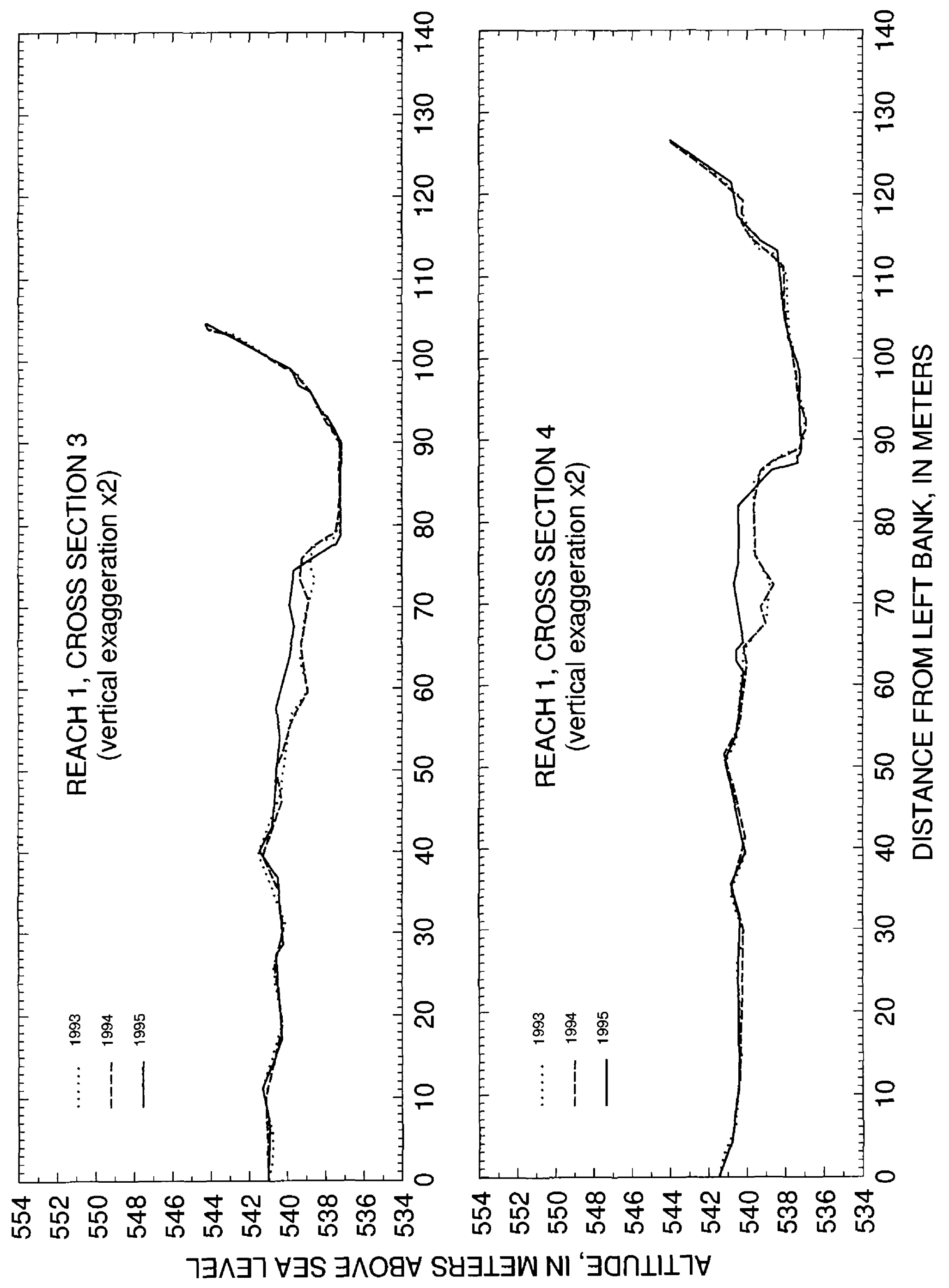




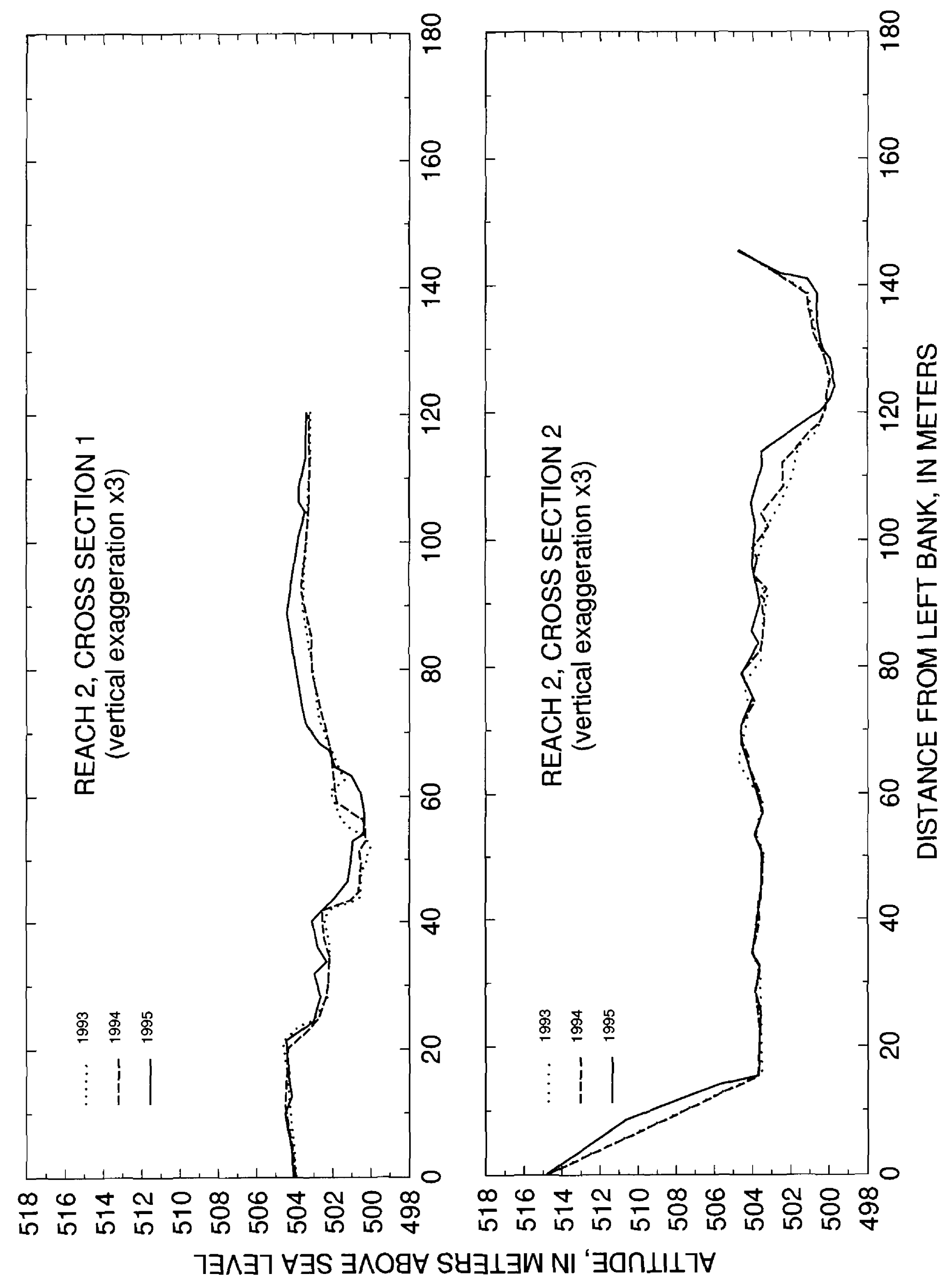




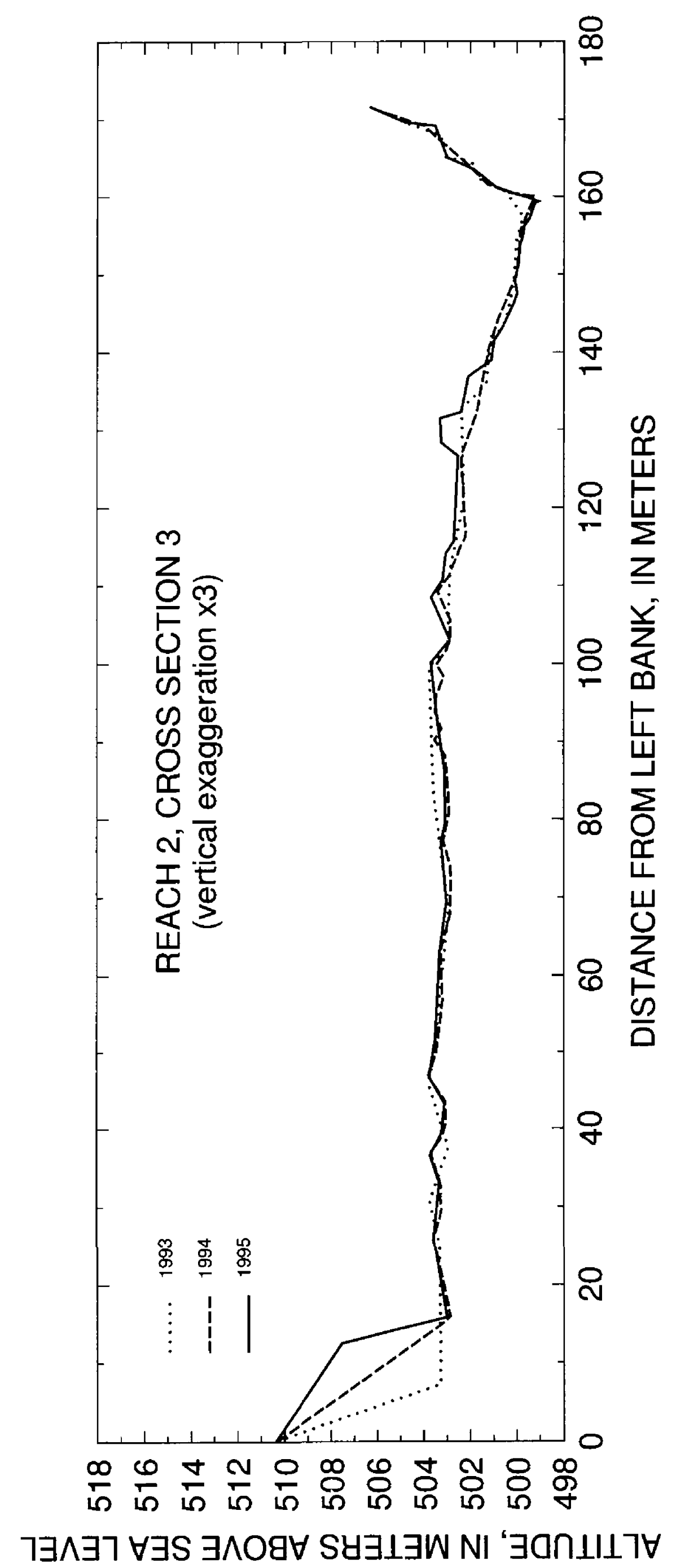




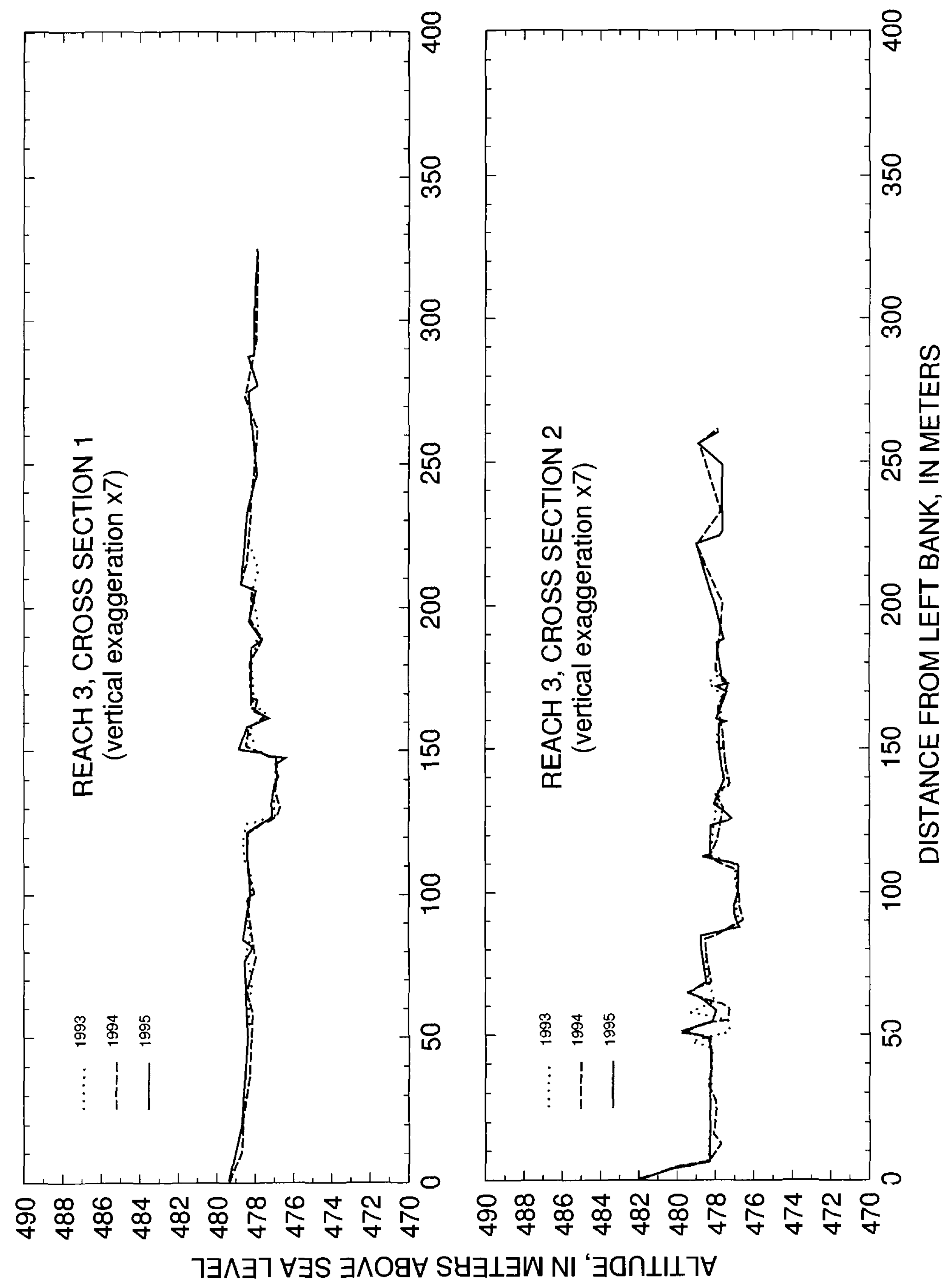




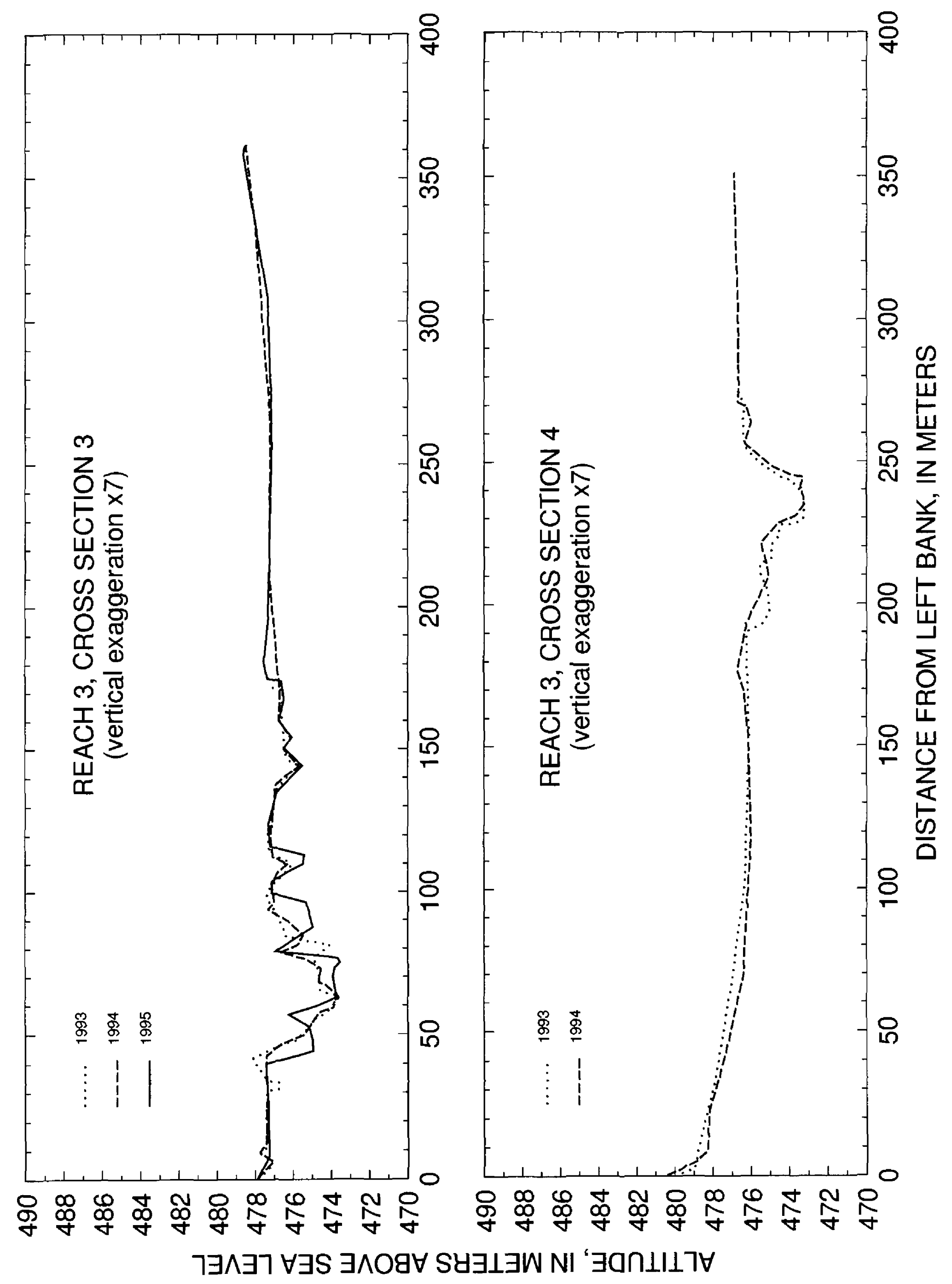




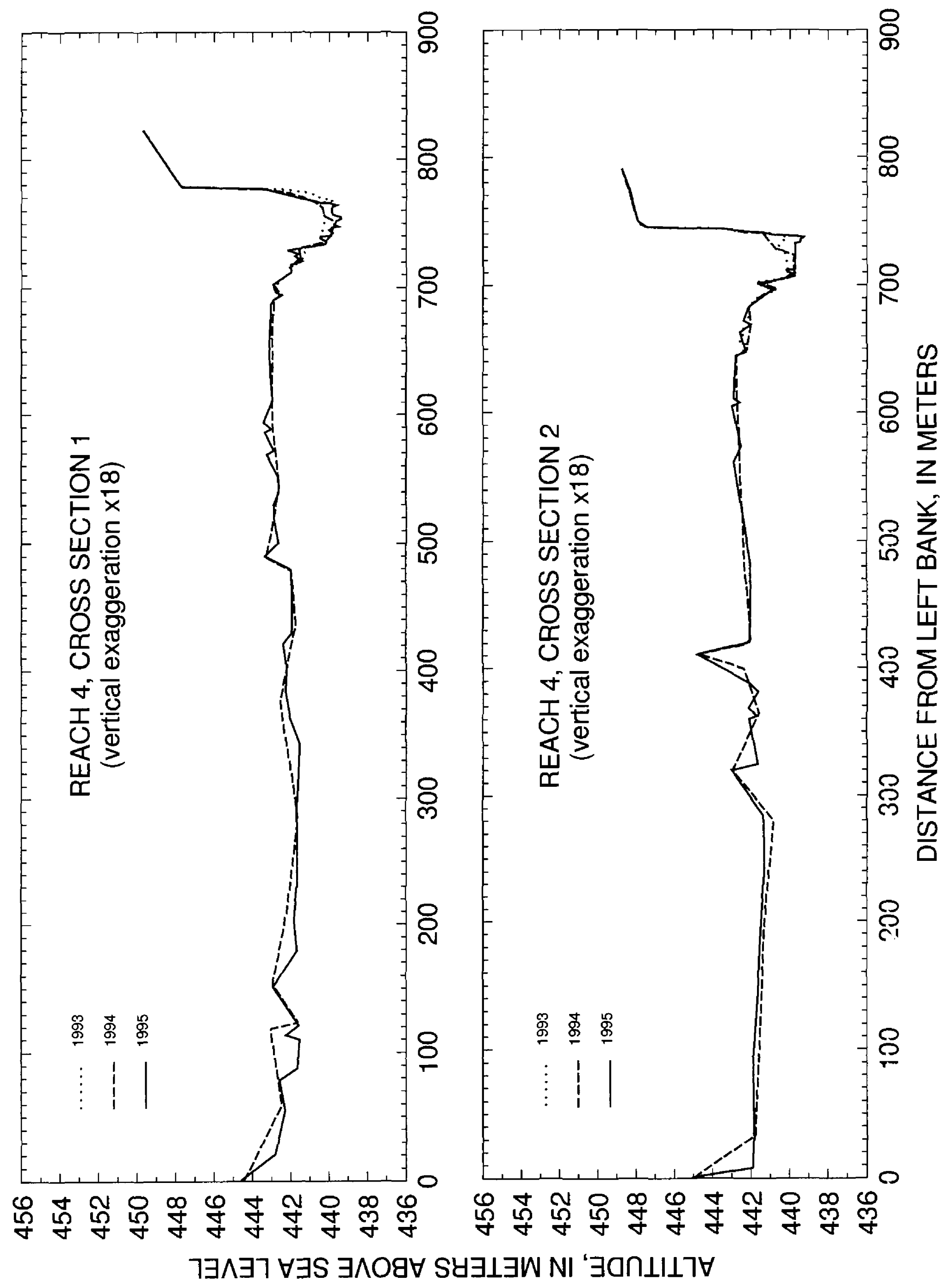




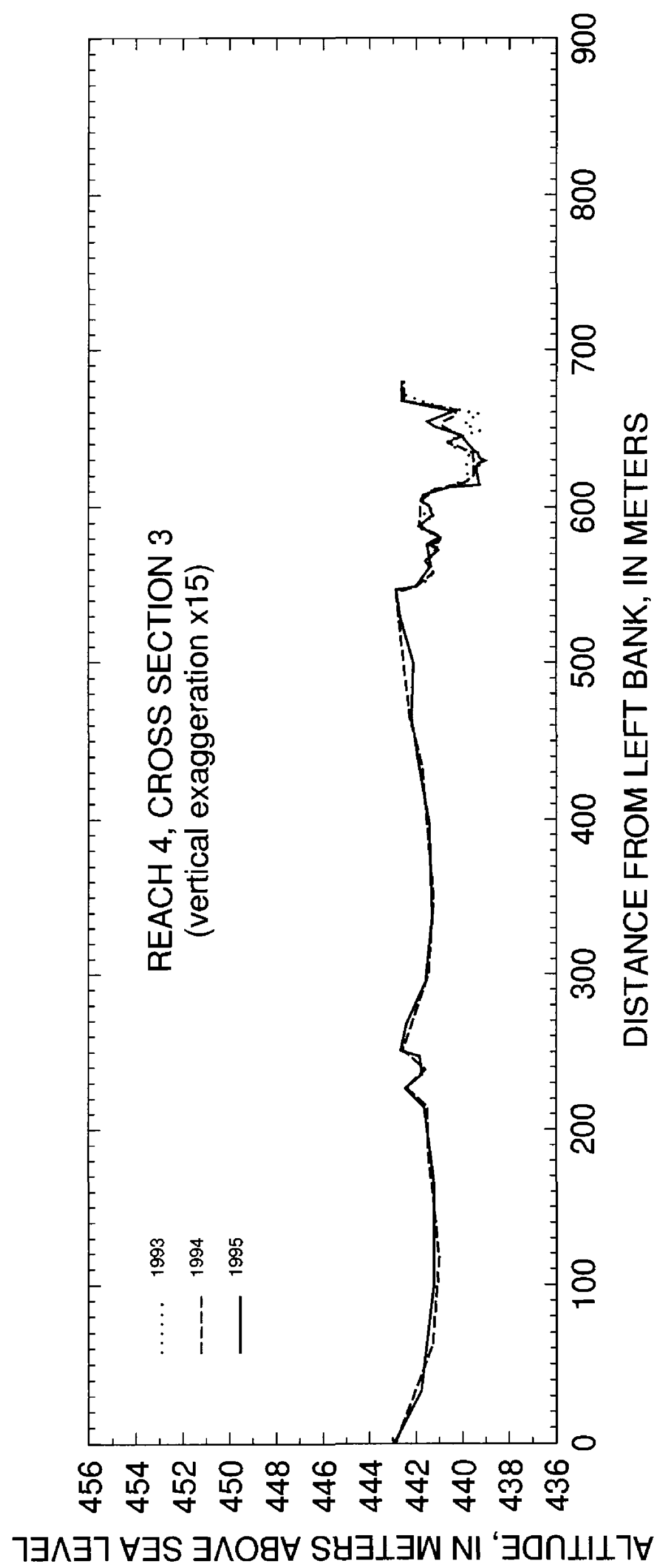




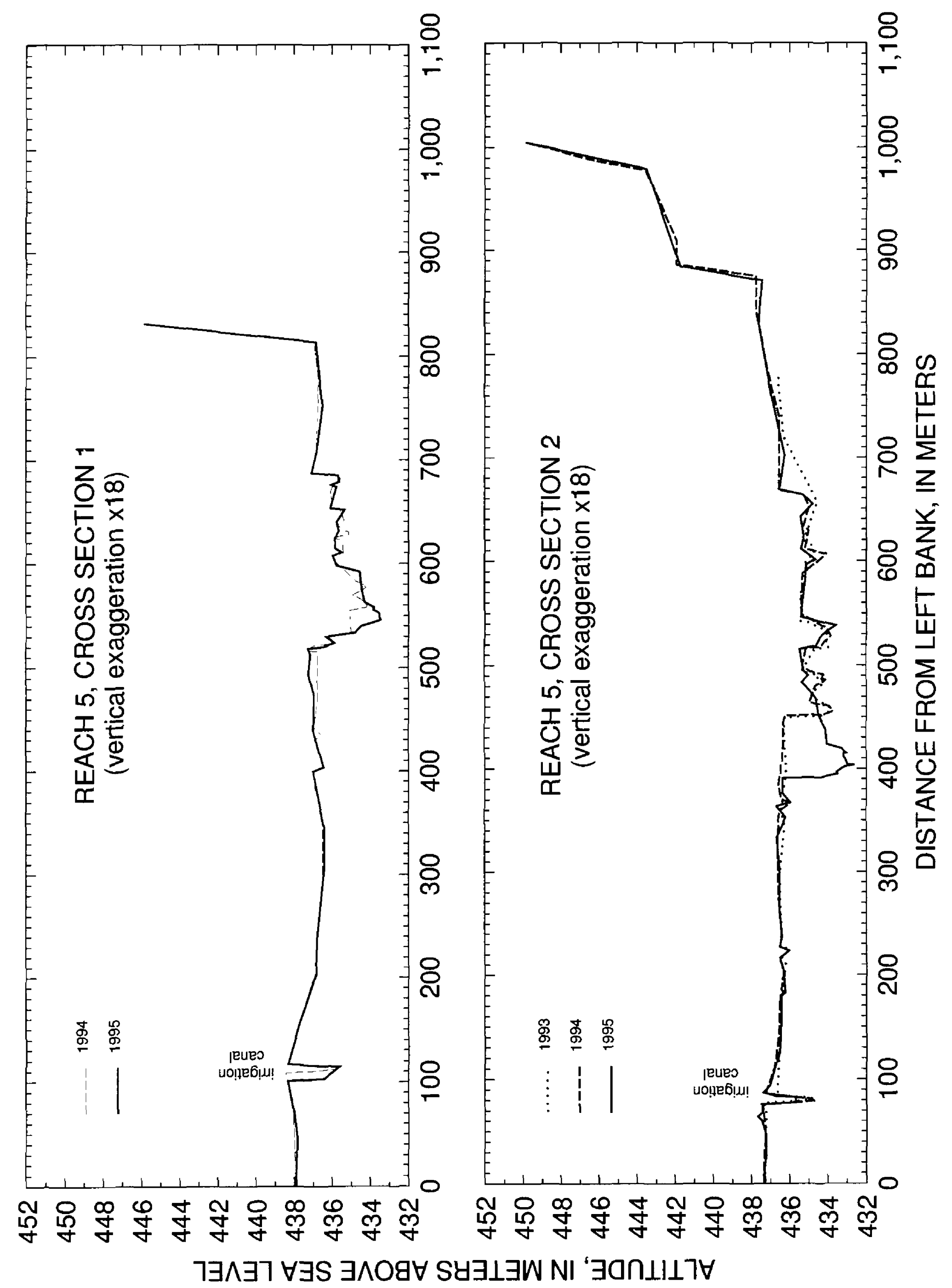




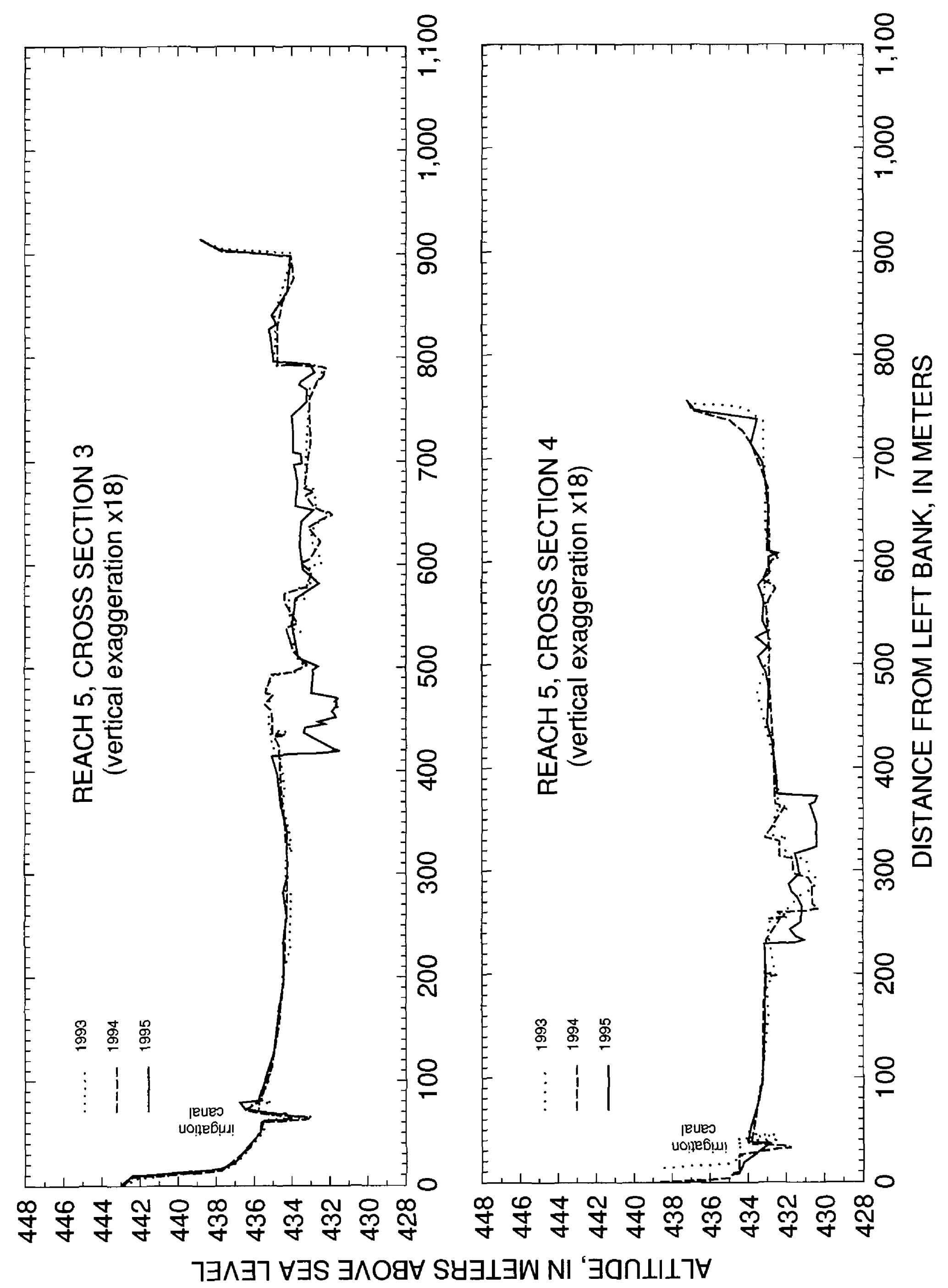




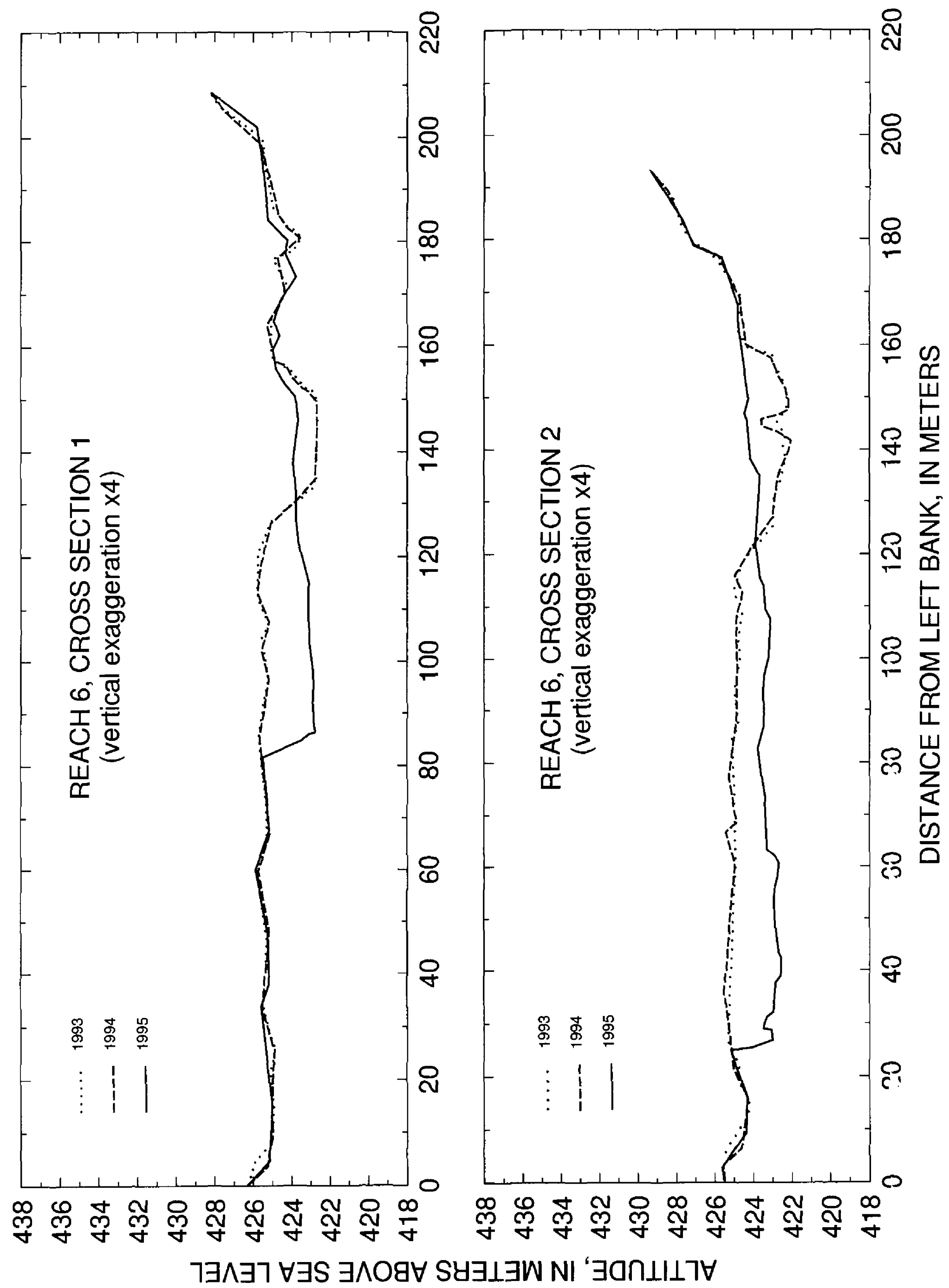




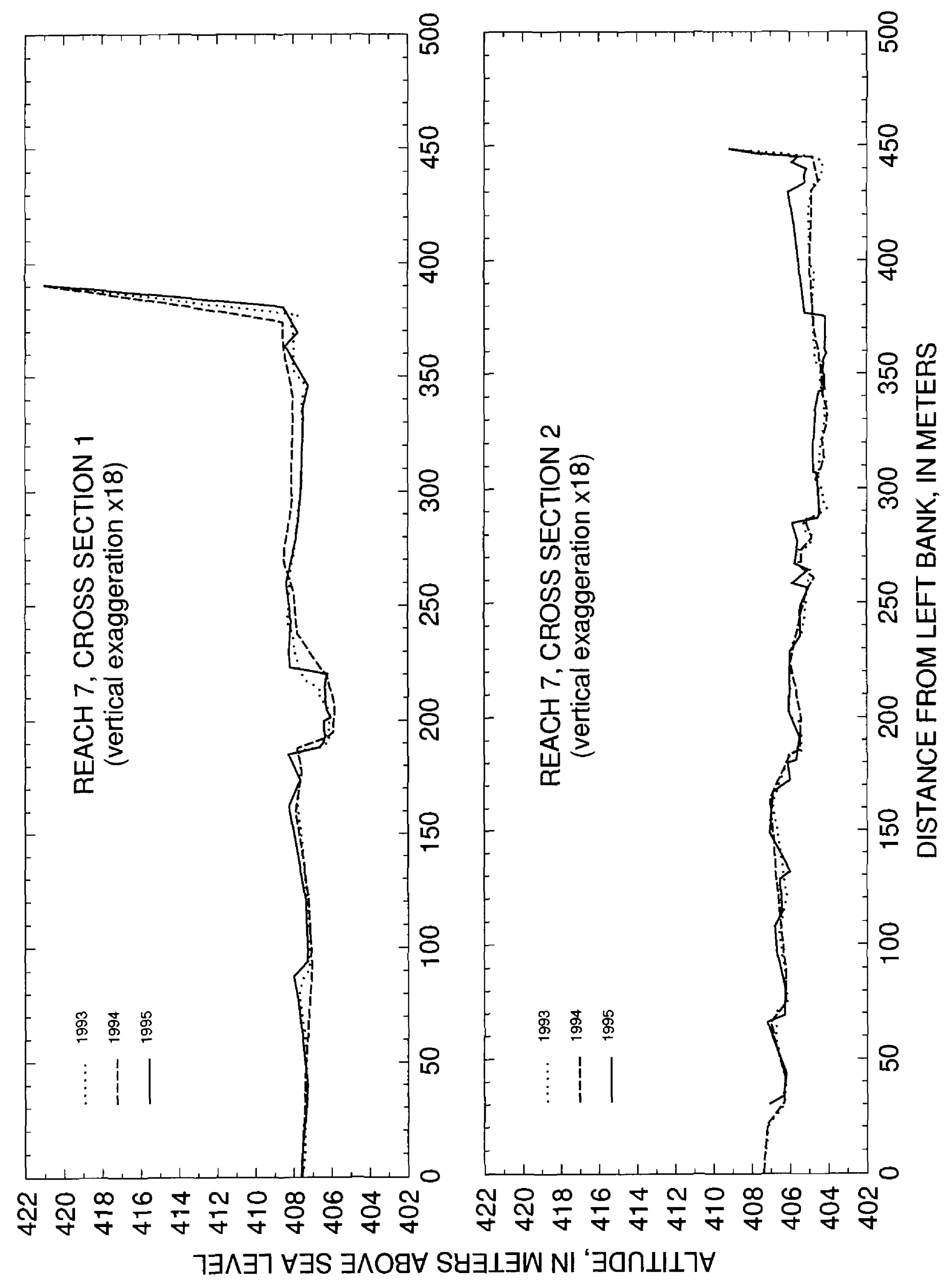




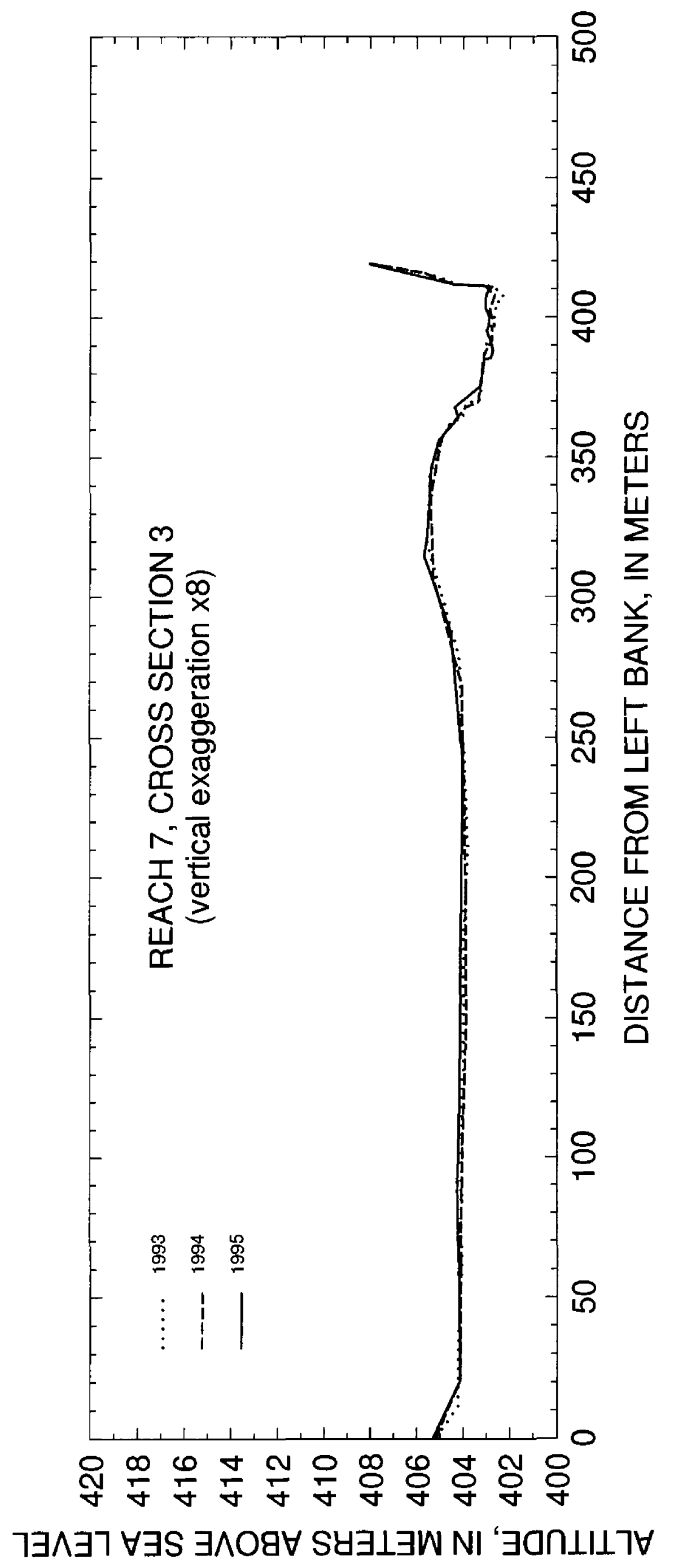




\section{APPENDIX C}

1994 Channel Geometry in Relation to Channel Geometry After Synthesized

100- and 500-Year Floods 


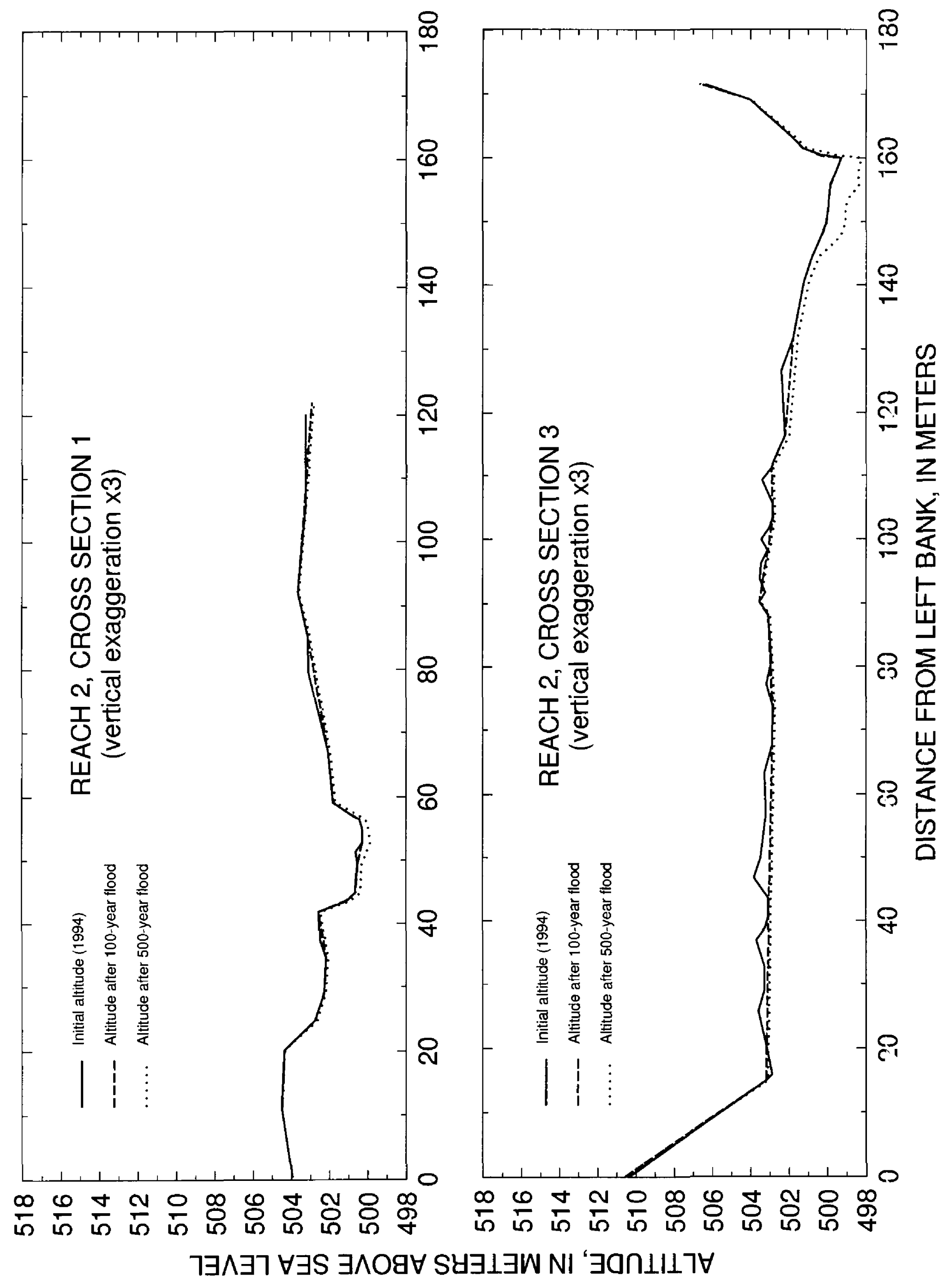




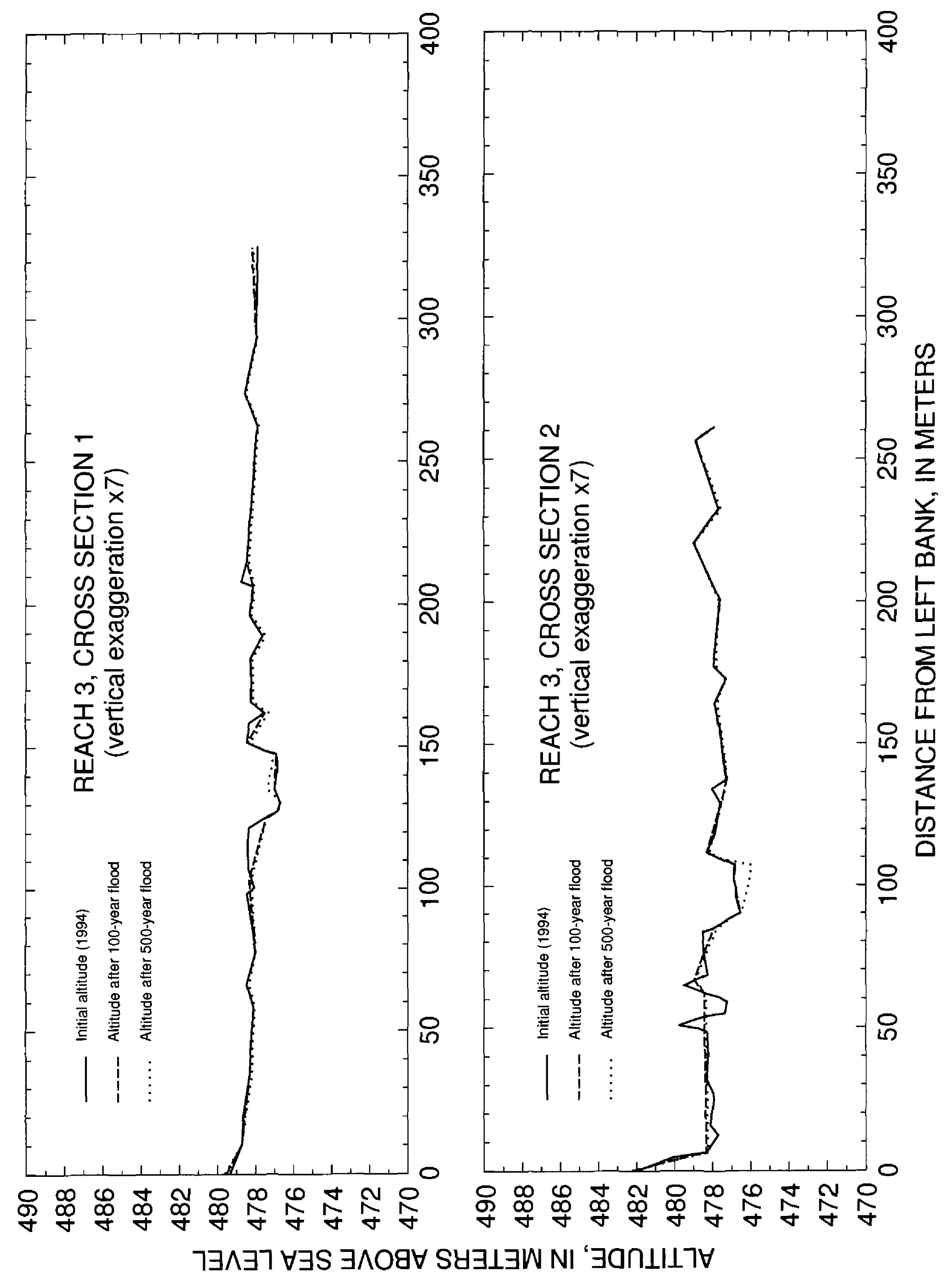




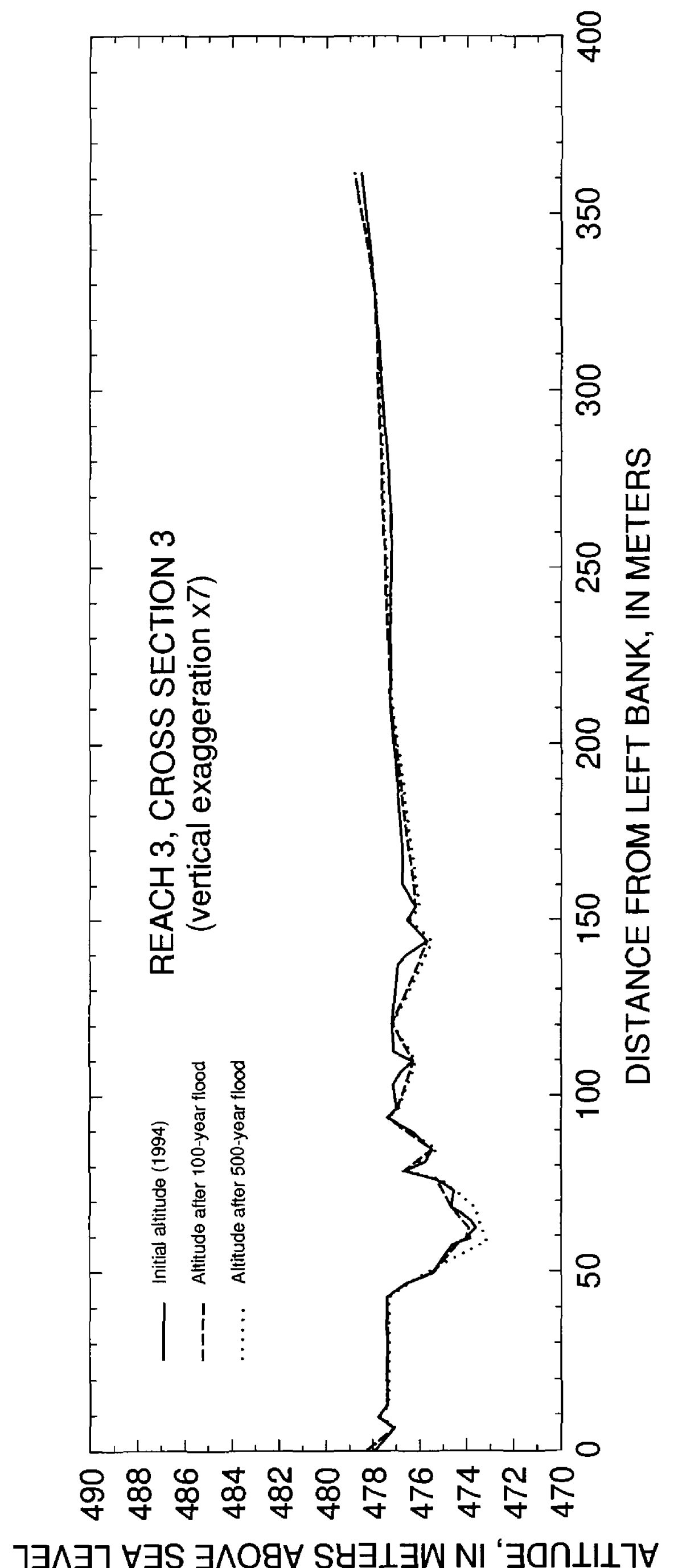




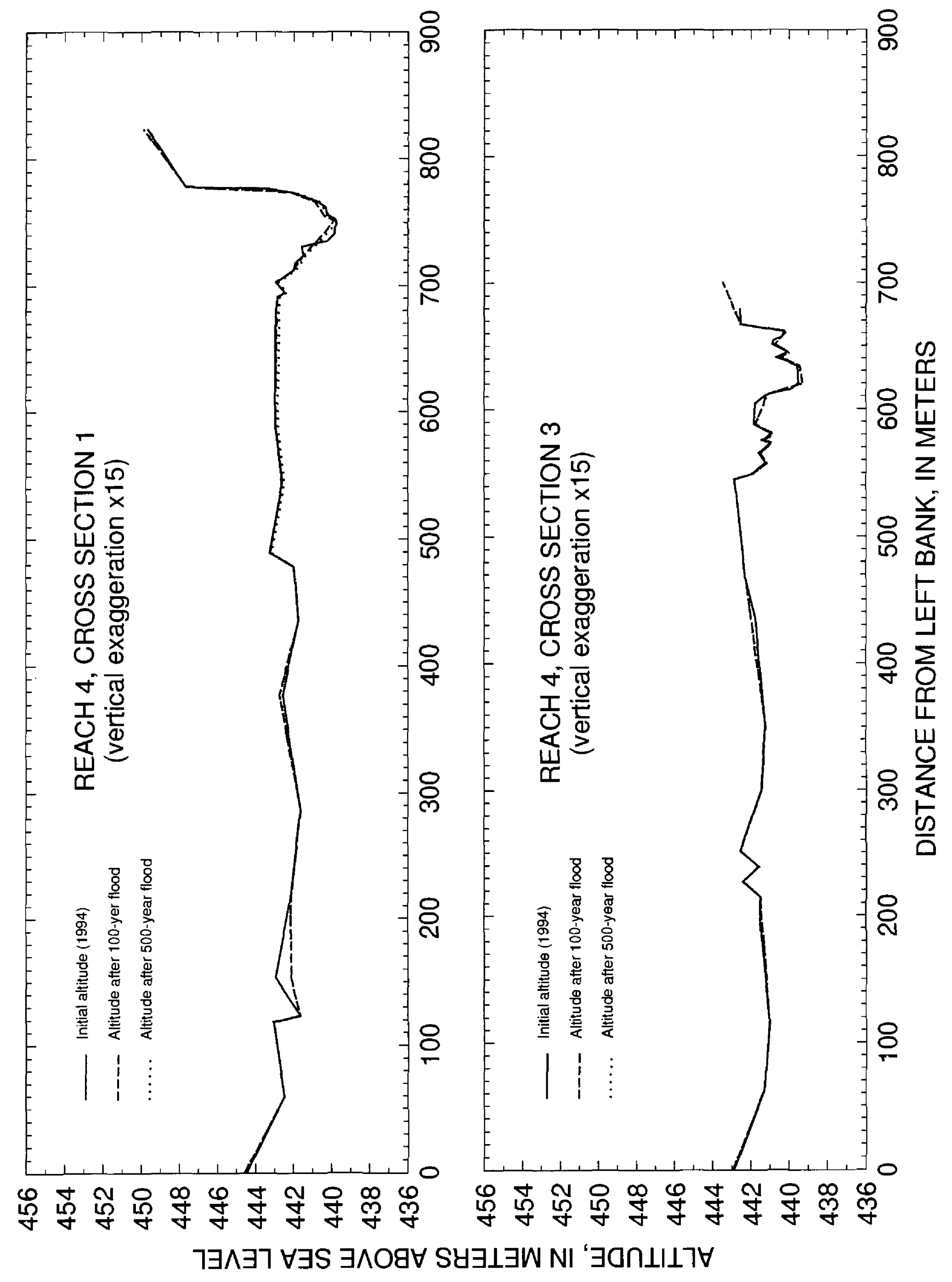




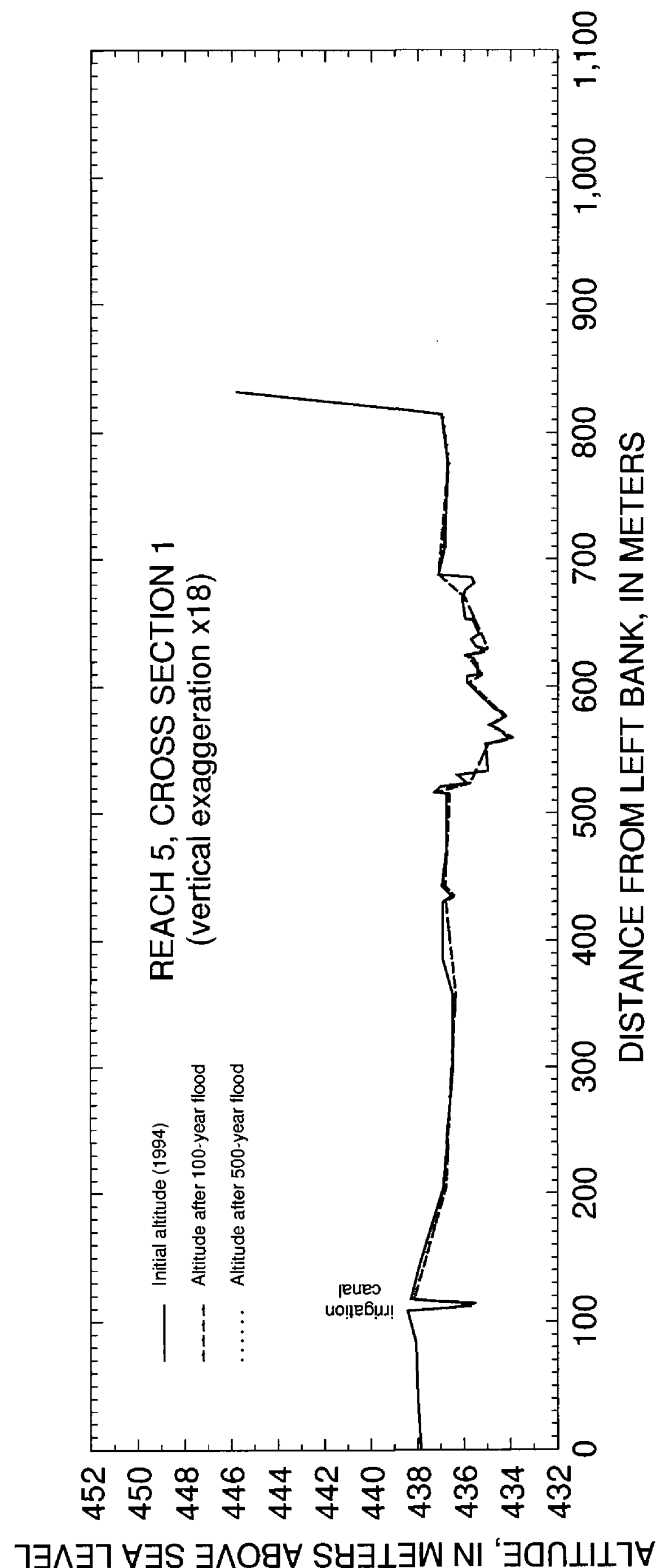




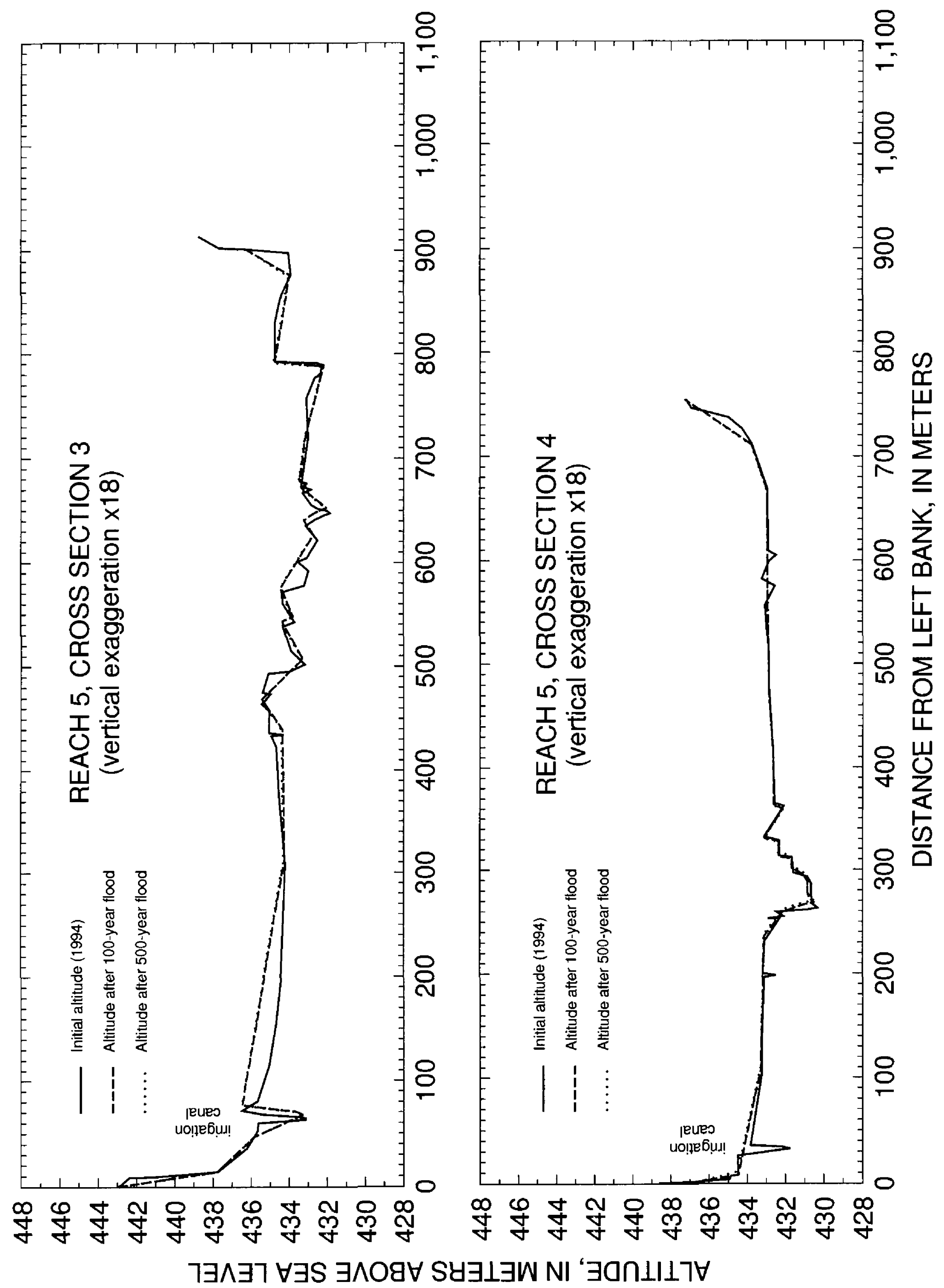




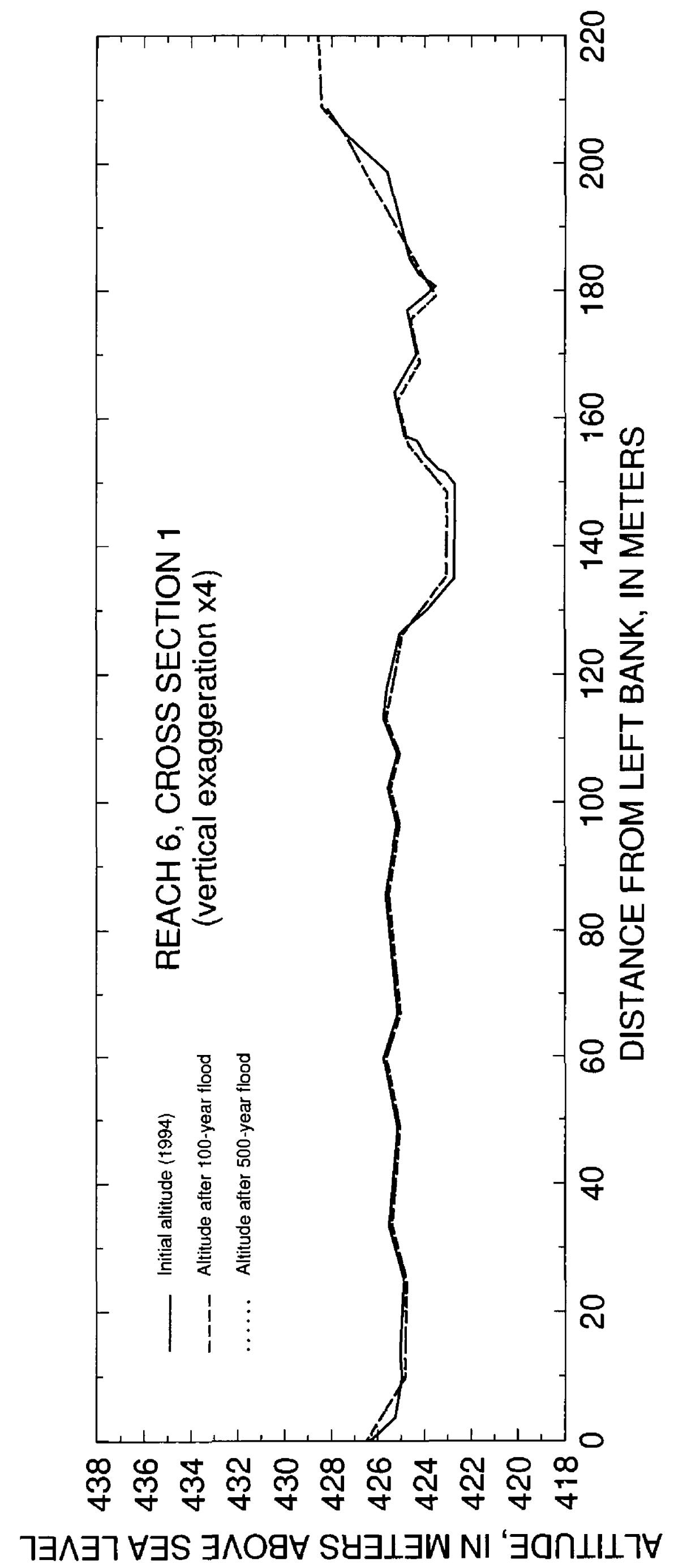




\section{APPENDIX D}

Name, Size, and Description of Input and Output Files for the Estimate of

Bridge Scour on the Virgin River, Southeastern Nevada 
Appendix D. Name, size, and description of input and output files for the estimate of bridge scour on the Virgin River, Southeastern Nevada ${ }^{a}$

\begin{tabular}{|c|c|c|}
\hline $\begin{array}{l}\text { Flle or directory } \\
\text { name }\end{array}$ & $\begin{array}{c}\text { Size } \\
\text { (bytes) }\end{array}$ & Description \\
\hline model_sourcecode.dir & 403,653 & Source code for BRI-STARS model version 3.3 , \\
\hline river.bdg & 15,521 & Input file used in model calibration for Riverside bridge. \\
\hline little.bdg & 27,011 & Input file used in model calibration for Mesquite bridge. \\
\hline river.dat & 1,277 & WSPRO file used in model for Riverside bridge. \\
\hline little.dat & 629 & WSPRO file used in model for Mesquite bridge. \\
\hline riverend.out & 28,925 & Calibration output file for Riverside bridge. \\
\hline litend.out & 21,193 & Calibration output file for Mesquite bridge. \\
\hline riverend.xs & 8,349 & Calibration cross-section output file for Riverside bridge. \\
\hline litend.xs & 6,770 & Calibration cross-section output file for Mesquite bridge. \\
\hline rivl00.rev & 15,565 & Input file used in model to estimate scour for 100-year flood at Riverside bridge. \\
\hline riv500.rev & 15,570 & Input file used in model to estimate scour for 500 -year flood at Riverside bridge. \\
\hline lit 100.rev & 27,057 & Input file used in model to estimate scour for 100-year flood at Mesquite bridge. \\
\hline lit500.rev & 27.020 & Input file used in model to estimate scour for 500-year flood at Mesquite bridge. \\
\hline rivl 00.out & 28,925 & Output file for 100-year flood at Riverside bridge. \\
\hline riv500.out & 28,925 & Output file for 500-year flood at Riverside bridge. \\
\hline lit 100. out & 26,711 & Output file for 100 -year flood at Mesquite bridge. \\
\hline lit500.out & 28,925 & Output file for 500-year flood at Mesquite bridge. \\
\hline riv100.prn & 7,492 & Cross-section output file for 100-year flood at Riverside bridge. \\
\hline riv500.prn & 7,482 & Cross-section output file for 500-year flood at Riverside bridge. \\
\hline lit100.prn & 6,717 & Cross-section output file for 100-year flood at Mesquite bridge. \\
\hline lit500.prn & 6,701 & Cross-section output file for 500-year flood at Mesquite bridge. \\
\hline river.61 & 3,294 & Cross-section output for 100- and 500-year flood for cross-section 6-1, Rivers de bridge. \\
\hline
\end{tabular}

${ }^{\text {a }}$ For more information, contact Public Information Assistant: phone (702) 887-7600; email usgsinfo_nv@usgs.gov. 